University of Montana

ScholarWorks at University of Montana

Graduate Student Theses, Dissertations, \&

Professional Papers

1952

\title{
The Kashmir question in the Security Council 1948-1952
}

Donald Frederick Graff

The University of Montana

Follow this and additional works at: https://scholarworks.umt.edu/etd

Let us know how access to this document benefits you.

\section{Recommended Citation}

Graff, Donald Frederick, "The Kashmir question in the Security Council 1948-1952" (1952). Graduate Student Theses, Dissertations, \& Professional Papers. 8644.

https://scholarworks.umt.edu/etd/8644

This Thesis is brought to you for free and open access by the Graduate School at ScholarWorks at University of Montana. It has been accepted for inclusion in Graduate Student Theses, Dissertations, \& Professional Papers by an authorized administrator of ScholarWorks at University of Montana. For more information, please contact

scholarworks@mso.umt.edu. 


\title{
THE KASHMIR QUESTION
}

\section{IN THE SECURITY COUNCIL, 1948-1952}

by

\author{
DONALD F. GRAFF \\ B.A., Montana State UnIversity, 1951
}

\author{
Presented in partial fulfillment \\ of the requirements for the degree of \\ Master of Arts
}

MONTANA STATE UNIVERSITY

1952 
The quality of this reproduction is dependent upon the quality of the copy submitted.

In the unlikely event that the author did not send a complete manuscript and there are missing pages, these will be noted. Also, if material had to be removed, a note will indicate the deletion.

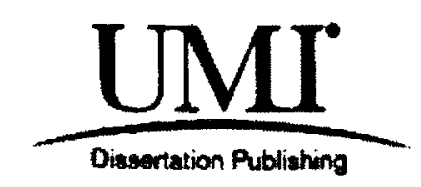

UMI EP39445

Published by ProQuest LLC (2013). Copyright in the Dissertation held by the Author. Microform Edition (C ProQuest LLC.

All rights reserved. This work is protected against unauthorized copying under Title 17, United States Code

\section{ProQuest}

ProQuest LLC.

789 East Eisenhower Parkway

P.O. Box 1346

Ann Arbor, MI 48106 - 1346 
This thesis has been approved by the Board of Examiners in partial fulfillment of the requirements for the degree of Master of Arts.
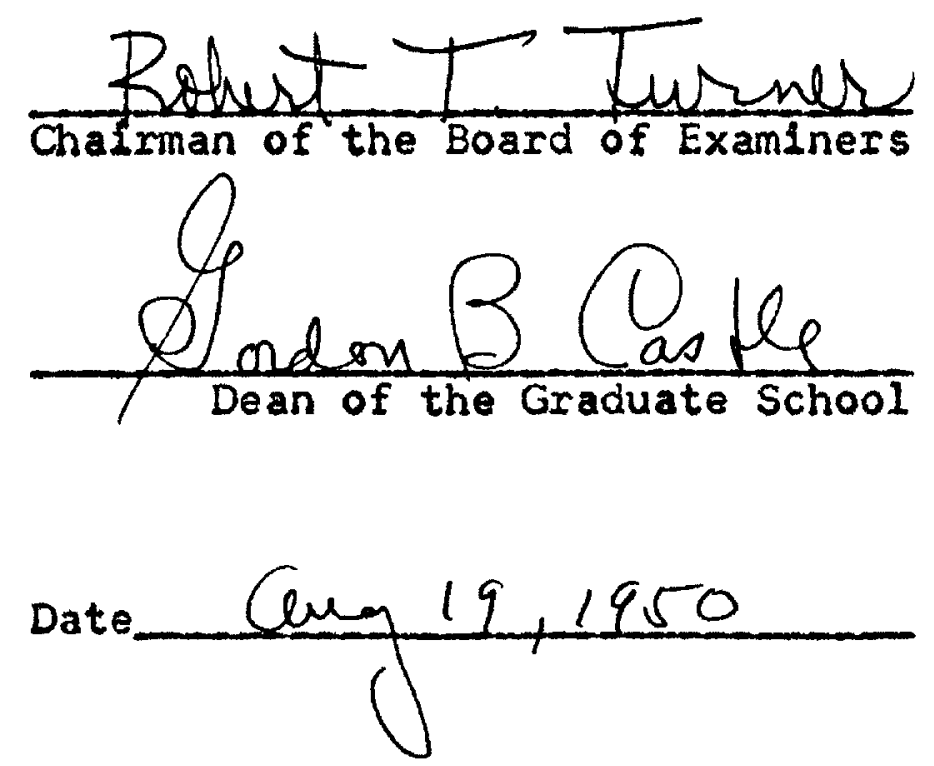


\section{"You adapt what you do to the circumstances of the case, the w11l of the partles and the necessities." Phillp Noel-Baker}




\section{PREFACE}

This study is an attempt to determine the Security Council's effectivness in maintaining peace in a dispute of the nature anticipated by the framers of the Charter. The Kashmir question is pecullarly adapted to such a study. Great power rivalry has rarely intruded and the veto power has not been a factor. The duration of the dispute affords an opportunity to observe Counc1l adjustment to long-term developments. And the Council has employed varlous disputesettiling devices in seeking a solution.

Although but one element in the broader Indla-Pakistan question, the Kashmir Issue InItiated Council consideration of the greater controversy and remains by far the most Important aspect. The additional issues figure in the study only where they are related directly to the Kashmir problem.

It is hoped that this investigation contributes to a clearer understanding of Council capabilities. In narrowing the area of disagreement and in bringing the parties within slght of a settlement, the Council has alded in forestalling open hostilities between Indla and Paklstan. Not the ultimate answer to international strife, the Council may yet contribute to peace, if only negatively by delaying war until martial passions have cooled.

$$
\begin{aligned}
& -i v- \\
& \text { D. F. G. }
\end{aligned}
$$




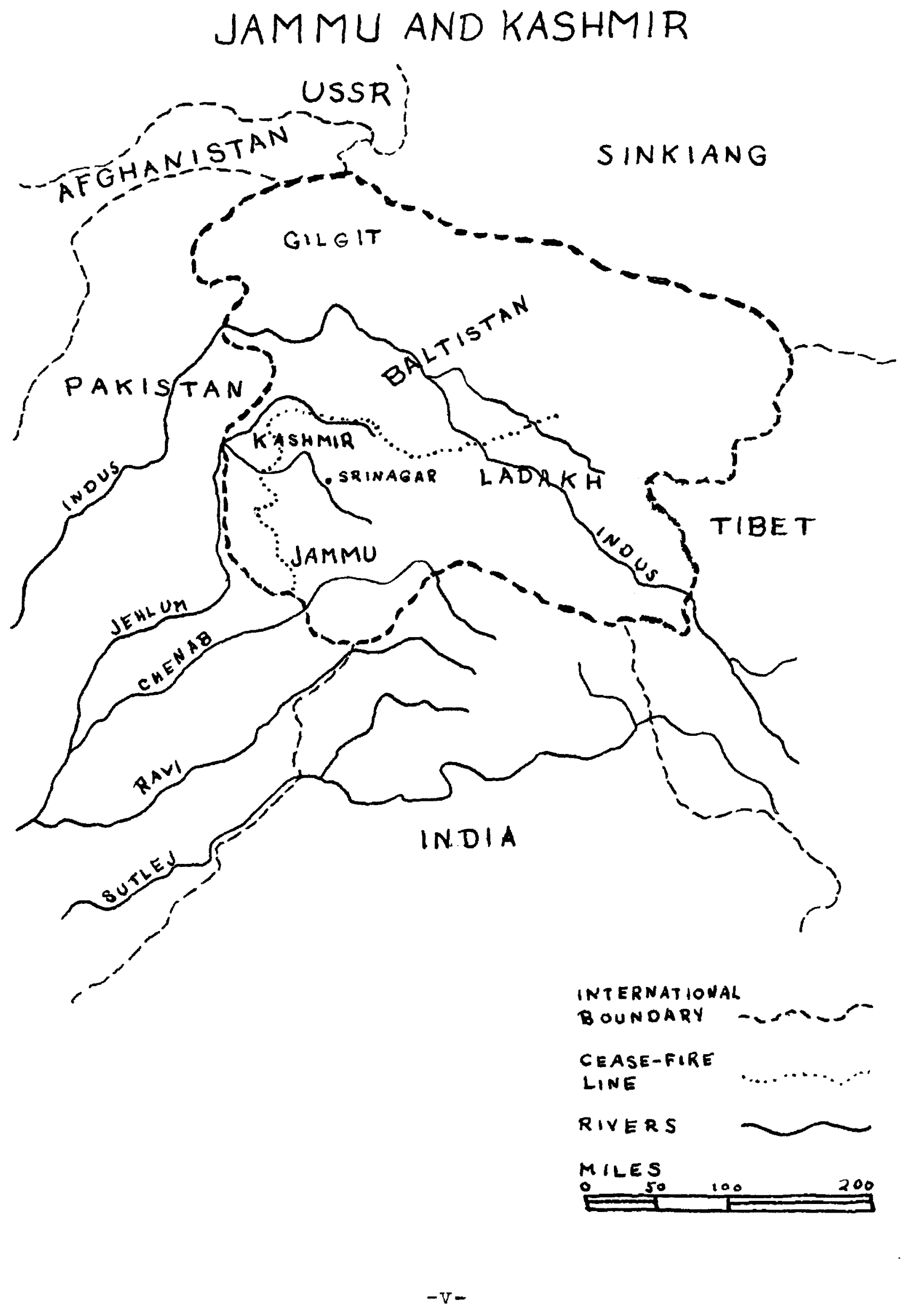




\section{TABLE OF CONTENTS}

Chapter

Page

I. BACKGROUNDS .............. I

II. COMPLAINT, COUNTER-COMPLAINT ...... 29

III. A QUESTION OF PRIORITY . . . . . . . . 54

IV. PARAGRAPH BY PAIIAGRAPH . . . . . . . 76

v. A MATTER of SUbstance ......... 97

VI. THIRD PHASE ............. 130

vII. SIGNIFICANCE . . . . . . . . 158

BIBLIOGRAPHY . . . . . . . . . . . . 173 


\section{CHAPIER I}

BACKGROUNDS

I

Each of the modern world's political phenomena is a visible result of myriad influences, a web of complexities clearly comprehended only in relation to all factors, past and present, which affect it. No problem in international politics has exclusive origin in a specific date or isolated Incident. Yet at some one point in the development of a situation it may be possible to say that this event or this date, while not the genesis, Is of such significance that it may serve as a logical beginning for a study of the problem. There exists today a complicated and prolonged dispute, already of almost flve-years duration, between India and Pak1stan over possession of a political unit called Kashmir. Many events were of great importance in the development of the Kashmir dispute. One stands out as marking something of a critical point between the generation of a dangerous situation over long centuries and the succession of lncidents in recent history that carrled anclent sores to the point of eruption.

On August 15, 1947, after three centuries of dominion In India, Great Britain granted full powers of self-government 
to the provisional administrations of Pakistan and the Indian Union. Not least among the problems facing the young dominIons during the first weeks of independence was the status, present and future, of several hundred semlautonomous princ1palitles which had been morticed with British-administered provinces in the framework of the Indian Empire. Theoretical1y. IIquidation of British suzerainty left the princely states Independent nations, free to remain Independent or to seek union with either India or Pakistan. Their official position had been one of alliance rather than subjugation to the Brltish Crown. The practlcalities of modern politics, however, appeared to dictate early accession to whichever dominion a given state was most closely assoclated with through geography, economy, and religion. A majority of state governments immediately sought accession; a few, Including several of the most important, did not.

Outstanding among the uncommitted states was Jammu and Kashmir, coveted by Indla and Pakistan because of Its great size and its strateglc and economic value. Kashmir's maharaja, Sir Mari Singh, ${ }^{1}$ was still negotiating with both dominions on the question of accession when, October 22, 1947, an armed force entered the state from the direction of Pakistan. The onslaught shattered the weak state forces and

lColonel H. H. Maharaja Sir Hari Singh, 1895-, is the fourth member of the Hindu Dogra dynasty, originally a princely Rajput family in the service of the Sikhs, to rule in Kashmir. A great grandson of the founder of the line. Gulab Singh. Sir Harl Singh succeeded to the throne in 1925. 
upset Kashmir's political equilibrium. Their identity was not yet certain before the invaders were besleging Srinagar, the capital. Powerless to halt the incursion with the remnant of an army at his disposal, the maharaja pledged Immediate union with India in return for milltary aid in the defense of his possessions.

The Indian government promptly accepted the offer and, over bitter Pakistanl protests, rushed contingents of the Indian army to the ald of Srinagar's defenders. Within days India and Pakistan were close to open belligerency over questions of the identity and supply sources of the invaders, the legality of Kashmir's accession to Indla, and the religious and political preferences of the state's inhabitants. While hostilities continued in Kashmir, the dominion governments exchanged accusations, demands, and proposals, but two months of negotiation distinguished by abaence of any inclinacion toward compromise failed to produce even a sign of agreement. On January 1, 1948. Ind1a referred the dispute to the United Nations Security Council, and Kashmir became a world problem.

Jammu and Kashmir is territorially the largest of the Indian states although its 84,000 square miles are largely a rugged and sparsely settled Himalayan mountain region. Situated at the northern tip of the former Indian Empire, the state consists of nine provincial districts--Kathua, Jammu, Udhampur, Mirpur, Riasi, Poonch, Kashmir South, Kashmis North, 
and Muzaffarabad--In the southwest; the eastern, sem1-Tibetan territories of Ladakh and Baltistan; and the northern tributary areas of Gilgit, Gilgit Agency, Gilgit Wazarat, Chilas, and the Tribal Territory. Kashmir's heart and 1ts richest district is the Vale of Kashmir which lies in the districts of Kashmir North and Kashmir South. Within the narrow confines of this famous valley are Srinagar and over one-third of Kashmir's four million people. The Vale is the true prize at dispute between India and Pakistan. Kashmir's southern and western boundarles touch the Punjab provinces of India and Pak1stan and Pak1stan's Northwest Frontler Province. Along an undefined frontier in the north and east lie Afghanistan, the Chinese provinces of Tibet and Sinklang, and--perhaps-the Soviet Union:

This is an undemarcated border of doubtful location in wild tribal country, much of which is above the clouds. The best maps show that a finger of China's Sinkiang Province Intervenes between Kashmir and Soviet territory, but the Indian Government understands. - that Russian control begins where one leaves Kashmir in the High Pamirs, on the Roof of the World.2

Historically, Kashmir has faced the region that has become Pakistan. The citles of the Indus valley are natural markets for the state's timber, woodwork, woolens, and agricultural produce. 3 The sole rall connection with the outside

2The New Yoxk Times, December 1, 1947. The agreement of Kabul between Russia and Great Britain in 1893 vaguely drew boundarles in this region. Afghanistan acquired narrow panhandle across the top of India (Kashmir) which was intended to meet a shorter extension from Chinese Sinkiang. However, the latter was never clearly delimited. York: Pakistan Delegation to the Security Council, 1951), p. 3. 
world is a spur line from Slalkot in West Punjab to Jammu and. unt1l recently, the only all-weather roads led to the West Punjab and the Northwest Frontier Province. Four of the great rivers of Pakistan, the Indus, the Jhelum, the Chenab, and the Rav1, whose waters are 11 feblood to irrigated areas in Pak1stan, rise in or flow through Kashmir. At a number of sites In the mountains of Kashmir the rivers offer possibilities for hydroelectrlc developments which could balance Pakistan's lack of coal. For Pakistan, these are reasons why "the governarice of all Kashmir by a potentially host1le India has been a prospect too fearful to be borne." 4

The modern Kashmirl is a cousin of the Punfabi to the south, although Ladakh, or Little Tibet, In the northeast is Inhablted by small Mongol-Buddh1st population. Largely peasants, the Kashmiris are predominantly Moslem with a Hindu and Sikh inority, the latter a varlant of HinduIsm, concentrated In Jammu, close to the Indian border. 5

Kashmir's remoteness and mountainous topography enabled It to enfoy a detached and solltary existence as an independent Hindu state prior to the Moslem Invasions of India. Little affected by the early Islamic incursions, beginning in 664 A.D.. It at last fell under Moslem domination in the

4"Kashmir and Jammu," Bound Iable, XI (June, 1950), p. 218. Pak1stan has reason to fear Indian control of the rivers. Partition gave India the headwaters of canal systems Irrigating West Punjab. Indla began to divert the waters to its own Punjab reglons, cutting off Pakistan's water supply.

${ }^{5}$ Government of Indlan. The Kashmir Issue (Delh1: Ministry of Information and Broadcasting, $\left.n_{0} d_{.}\right)$. pp. 1-2. 
fourteenth century and most of the population was forclbly converted to Nohammedanism. With the annexation of Kashmir by the Moguls in 1586. the Vale became the summer capital of the Empire but by the middle of the eighteenth century a measure of independence had returned. As Mogul dominion wilted before the expanding power of both British and Sikhs, the governor of Kashmir began to exerclse authority independently of the capital at Deln1.6

Scarcely had autonomy been achieved before warlike Pathans overwhelmed the Vale and established an Independent Moslem dynasty. By 1800 the Sikhs had driven the Moguls from the Punjab and In 1819 they wrested Kashmir from the Pathans, only to lose it to the British in 1846 following the first Sikh war. ${ }^{7}$ Uninterested at the time in their acquisition, the British, In the Treaty of Amritsar, ceded the vale to Gulab Singh, 8 a HIndu of the Dogra sect and ruler of the small princlpality of Jammu under Sikh suzerainty, who offered to pay the 7.5 million-rupee indemnity (about $\$ 2,250,000$ ) levied upon the defeated Sikhs. Already in control of the Ladakh and Baltistan areas bordering the Vale, Gulab Singh consoll-

6G. F1tzGerald-Lee, "Kashmix," Contemporary Review, CLXXIX (February. 1951), P. 93.

7 Sir W1lliam Barton, "Pakistan's Claim to Kashmir," Eorelon Affairs, XXVIII (January. 1950. Pp. 299-300.

${ }^{8}$ Gulab Singh, a Rajput chleftaln ralsed to high office under the Sikhs, received the principality of Jamnu from the Sikh leader Ranjit Singh. After the Battle of Sabraon concluded the first $51 \mathrm{kh}$ war, in which he was neutral, Gulab Singh was a spokesman for the Sikhs in arranging peace with the British. 
dated his terrltorles, transferred his capital to Srinagar, and established the modern ruling house on the soll of Kashmir.

The Dogra administration followed a typically autocratic pattern. The household expenses and privy purse of the maharaja consumed approximately one-third of the state revenue while public services were ignored. Dogras ind royal favorites, almost Invariably Hindu, filled government positions and exclusively controlled the militia; the Moslem peasant population was forbldden arms of any description. The prime ministers, usually Hindu Punjabis, were non-Kashmiris and a few Dogra nobles possessed most of the land in large feudal grants:

Against the discontent which the perpetuation of an antiquated land system and arbitrary rule inevitably aroused, the Dogra regime was explicitly safeguarded by its pecullar relation to the imperial authorities. Together with the other princely states which had helped the British put down the famous Sepoy Rebellion of 1857. Kashmir came to be treated as an especially valuable prop of empire. 9

An uprising in 1930 was the first serious attempt to temper the maharaja's power. Despite ald from the British in suppressing the rebellion, the prince was compelled to concede elementary civil liberties and to establish a legislature of limited powers. In the new atmosphere of relative freedom,

\section{${ }^{9}$ Alice Thorner, "Issues in Kashmir," Ear Eastern} Survey, XVII (August 11, 1948), P. 174. Two Indian spokesmen. Gopalaswami Ayyangar and Sir Benegal Narsing Rau, In Council discussions on the Kashmir question were at one time prime ministers of Kashmir. 
Shelkh Mohammed Abdullah, 10 a young Moslem educated In India, founded the All-Jammu and Kashmir Moslem Conference which, although linked with the nonsectarlan Congress party in Indla, was concelved as a defender of Moslem rlghts. In $1938 \mathrm{Jawa-}$ harlal Nehru, 11 a close personal frlend, advised Sheikh Abdullah to open the ranks of the Conference to all Kashmiris, irrespective of caste or religion. The organization, renamed the All-Jammu and Kashmir National Conference, soon became an Important force in Kashmir's politics. Its sole rival, save for the maharaja's personalized government, was an exclusively Moslem party formed when a few of the origlnal members split w1th Sheikh Abdullah. The Moslems revived the old name and followed the polltical lead of the conservative and communalminded Moslem League In Ind1a. But in Kashmir, as well as throughout India, Sheikh Abdullah was recognized as the state's outstanding popular leader. 12 When, in a memorandum to the

10 Sheikh Mohammed Abdullah, 1905- is the son of a craftsman from the village of Soura near Srinagar. After working his way through the University of Allgarth in India, he returned to Kashmir to find success in a professional field virtually Impossible for a Moslem. His orlginal Moslem Conference was intended as a rallying point for advocators of Moslem rights.

11 Pand1t Jawaharlal Mol1 Ata Nehru, 1889- Is of Kashmirl descent himself. Educated in England, he entered politics in 1918 as secretary of the Home-Rule League in Allahabad. He jolned the Congress party in 1920, gaining recognition as the leader of the socialist wing. A member of the viceroy's counc1l in 1939. Nehru was vice-president and minister of external affairs in the interim government of 1946. He has been prime minister and minister of foreign affairs of the Indian Union since 1947. In 1946 he was forbidden entry to Kashmlr to defend Shelkh Abdullah, on trial for agitating against the maharaja's government.

\section{Thorner. 20c. cit.}


British cabinet mission of 1946, he denounced the Treaty of Amritsar and Intitlated a "Quit Kashmir!" campalgn against the maharaja, the prince reacted promptly by arranging the Sheikh's seventh imprisonment at moment when unrest in Kashmir was about to erupt in violence. 13

Modern communications had begun to penetrate the mountain principality, destroying the isolation which in the past had enabled it to remain somewhat aloof from the political currents of the Indian plains. Despite the desires of its ruler, Kashmir could not avold the effects of the drive for independence which threw all India into turmoll.

Born with the commerclal activities of the East Indla Company in the sixteenth and seventeenth centuries, British dominion in India was consolidated after steady milltary and political conquest routed all rlvals-Moguls, French, and sikhs. With the formal assumption of the government of India by the Crown in 1858, British political control of the subcontinent was established in a pattern that was to endure unt11 1947. The Indian Emplre was a conglomeration of British provinces, under the direct rule of the Crown, and of many native states, nominally independent and allied rather than subjugated to the imperial authorlty. The viceroy and his council were the autocratic apex of this political community. Desire for representation on the viceregal councll and for eventual self-government produced the Indian nationallst 
movement. But with natlonalism came the theory of communal1sm, bellef In the incompatability of the Hindu and Moslem comrunities, which was encouraged by the Britlsh with the hope of retarding the growth of national1sm through interfactlonal strife, 14

The flrst of the great independence parties, the Indian National Congress, was established in 1885.15 At first it drew support from both major religions, but in 1906 arch-conservative Moslem landlords and princes, hostile to the radical tendencles of Congress, withdrew to form the AllIndia Moslem League, the oldest of parties based on communal15m. 16 However, religlous differences had not yet assumed sufficlent importance to prevent Congress and League from cooperating in the early years of the struggle for self-government. Jogether they worked for provinclal popular administrations and for admission of Indian members to the viceroy's council. Although unity frayed perceptibly during this per10d, a serious split did not come cunt1l the passage of the Parliamentary Act of 1935,17 designed vo provide the provinces with considerable self-government while retaining British

14Daniel Thorner. "Hindu-Moslem Conflict in India." Ear Eastern Suryey. XVII (April 7, 1948), p. 77.

${ }^{15}$ Sir Verney Lovett, A Histery of the Iodian Nationalist Movement (New York: Freder1ck A Stokes, 1920), p. 34 .

16 Henry Noel Brallsford, Sublect Indla (New York: John Day. 1943), p. 100.

17H. G. Rawlinson, "Backgrounds: II Indla," spectator, CIXXVIII (April 25. 1947), p. 459. 
control of the central administration. India was to be a federation with a relatively weak central government exercising powers of forelgn affairs, defense, and communications. The princely states would enfoy an autonomous status in the union. Despite its broad concessions to popular government, the plan was acceptable to nelther the League nor Congress. The Moslems, fearing that the central authority would be dominated by the more numerous Hindus, insisted that the federal government be further weakened by being denied specifically the power of taxation. Congress saw the federal administration as already too weak and demanded that it be given greater powers. Nevertheless, the portions of the act relating to the provinces were implemented and discussion on the eventual form of the central government was still in process when, in 1939, a world war introduced a new factor into the drive for Independence.

While the British government concentrated on the succession of catastrophes in Europe, unrest in Indla increased. The British offered first a vague "after-the-war" promise of greater self-government, then dispatched the Cripps mission 18 with an offer of a ciominion-status post-war government based on the act of 1935 in return for a truce cn political activity during the war. In rejecting the Cripps proposal,

\section{c 18The Cabinet mission of 1942 was headed by S1r} Stafford Cripps, a leadir.y Labor party spokesman and minister of IIc-ili production in Britain's wartime coalition ministry. 
Congress leader Mohandas K. Gandh1' 19 termed it "a post-dated cheque on tottering bank which might come back with the endorsement. "No effects'."20 The British met the subsequent disturbances by Imprisoning the Congress leadership for the remalnder of the war emergency, leaving the league free to. extend 1ts power. The Moslems galned control of a number of provincial governments and spoke out more clearly for an independent Moslem state, Paklstan, an aim first formulated in the Lahore Resolution of 1940.21

Following conclusion of European hostilities, Britain's new Labor government turned to implementing a campaign pledge of Indian Independence. The Cabinet mission of 1946 offered Congress, the League, and the princes a complex plan for a federated dominion of India, based on the act of 1935 but providing for voluntary "grouping" of provinces in smaller

${ }^{19}$ Mohandas Karamchand Gandh1, 1869-1948, was universally regarded as the living spirit of Indian independence. Soon after entering politics, Gandhi became the leading political and spirltual spokesman of the Congress party. formulating his anti-British pollcy of passive noncooperation in 1919. He advocated home rule, the revival of home industries, agrarian reform, and inter-religion harmony and was an intransigent foe of partition. He was assassinated in 1948 by a member of a fanatical Hindu group advocating violence against Moslems.

$$
20 \text { Brailsford, p. } 52 \text {. }
$$

${ }^{21}$ The Lahore Resolution demanded independent status for provinces in which Moslems were in the majority--Sind, Baluchistan, Northwest Frontier Province, and the Punjab, all in the northwest, and Bengal in the east. The first three were overwhelmingly Moslem but Punjab was only 57.1 per cent Moslem and Bengal but 54.7 per cent. (Dr. O. H. K. Spate, "Partition of India and the Prospects of Pakistan," Geographic Bexlew, XXXVIII, January, 1948, p. 6.) 
federations within the All-India Union. 22 The Moslem League recognized the proposal as the essence, if not the letter, of Pakistan and accepted. However, when Congress rejected the plan because of the weakness of the central government, the League announced that no longer would it consider compromises; henceforth its single goal was an independent pakistan. With the failure of the Cabinet mission, new disturbances, this time of an ominous religlous character, broke out In the Punjab and Bengal. On February 20, 1947, Whitehall aggravated an already tense atmosphere by announcing its intention of withdrawing from India in the near future, despite the inability of Congress and League to agree upon the structure of an independent state. The complete British program. made public on June 3, guaranteed Pakistan's existence for "it is clear that any constitution. - cannot apply to those parts of the country which are unwilling to accept it."23 There was also a reference to the princes:

His Majesty's Government wish to make it clear that the decisions announced above relate only to British India and that their policy toward the Indian States contained in the Cabinet Mission of May 12, 1946, remains unchanged. 24

It appeared that the British government was underwriting the autonomy and powers of the princes in any. Indian federation which might be constructed.

\footnotetext{
22S. Chandrasekhar, "Freedom for India?" Ear Eastern Survey, XV (July 3, 1946). p. 198. 23"British White Paper on India," Current Histery. XIII (July, 1947), pp. 36-38. ${ }^{24}$ Lee. Elt.
} 
Sprawled across the face of Indla were $562^{25}$ princely states, accounting for one-half the area and one-fourth the population of the entire sub-continent and ranging in size and wealth from glant Kashmir and Hyderabad to midgets with half the acreage of Central Park:

Many of these States have roots so deeply estab11shed in the soll that the time of their seeding is lost in the mist of old tradition. They were in India before a Muslim set foot on Indian soll east of the Indus, before the first European ship cast anchor in the water of an Indian bay. before Queen Elizabeth slgned a charter for trade in the East Indies, and centuries before the first political party in India was born. 26

The exact political status of the states was, to some extent, a mystery even to the British. Prlor to the Crown's assumption of the Indian government, relations between the princes and the East India Company had been governed by a web of treaties which recognized, in varying degrees, the "sovereignty" of each potentate. In the proclamation of 1858, Queen Victoria promised scrupulously to maintain the engagements.27 In return, the princes ceded to the Crown control of their foreign affairs, communications, and defense and recognized the paramountcy of the Crown:

${ }^{25}$ The exact number of states was uncertain, varying from under four hundred to nearly seven hundred according to the definition of "sovereign" since some states were feudatorles of others. The compromise figure adopted by the Political office of the Government of India was 562. Many of the "states" were such by courtesy only for most of the smaller units were nonviable economically and politically.

${ }^{26}$ Sir Geoffrey F. de Montmorency. The Indian States an Indian Eederation (Cambridge University Press, 1942), p. 17. 27 Insis.. p. 47. 
The doctrine of paramountcy. - In very general terms may be sald to be the taking of action by the British authority for the common weal in a direction not specifically covered by treaty or engagement. . .28

The resultant legal position of the princes was compl1cated and often contradictory. Thelr states were not British territory nor were their subjects British subjects, although they were British-protected persons. The authority of the rulers in state internal affairs was wide but in all cases Iimited by relationship to the paramount power:

The States are equally ent1tled to Brit1sh protection and defence from agression and to an effective guarantee of survival and integrity. In the territorles of the States British-Indian law does not epply. The British-Indian Central and Provincial legislatures have no power to leglslate in regard to the affairs or subjects of the States: and the HIgh Courts and chlef courts of British India have no jurisdiction in their territorles. 29

This "Indian India" considered itself in direct alliance with the occupant of the British throne and was held together by the common headship of the viceroy, who "as Governor-General - - presided over the Government of India and as Crown Representative. . exercised paramountcy over the states." 30 The Office of Polltical Affairs in New Delhi administered offlclal relations between the viceroy and the states.

Both parties viewed the arrangement with satisfaction. Buttressed by Britlsh power, the princes rested secure in

$$
\begin{aligned}
& 28 \text { Ibid., p. } 55 . \\
& 29 \text { Ibid., p. } 15 . \\
& 30_{\text {Sir Percival Griffiths, "Struggle for Stability." }}
\end{aligned}
$$
19th century. CXIIV (July, 1948), P. 11. 
their autocratic privileges and became Britain's most loyal supporters; "they look like Indians, but are in fact the bodyguard of the British Viceroy."31 To Whitehall, the states were 1sland fortresses, the strongest props of the empire. as their loyalty during the Sepoy Mutiny and two world wars proved. Canning thought them the surest guarantee of Brit1sh power:

It was long ago sald. . . that if we made all India into zillahs (or British Districts) it was not in the nature of things that our Emplre should last flfty years; but that if we could keep up a number of native states without political power but as royal instruments, we should exist in India as long as our naval supremacy was maintained. Of the substantial truth of this opinion I have no doubt. . .32

The system was all too effective. Mile the nationalist movement forced concessions in Brit1sh India, the states remained autocratic, frozen in the nineteenth century. As late as 1940 only twenty-three boasted some type of consultative assembly, and in only one ${ }^{33}$ did responsible self-government exist:

The depth of the loyal feeling of the Princes is now an Immutable fact, which has to be reckoned with. . This sentlment in the case of the Princes has had a tanglble result in the fact that the cry for an independent India, so often volced by the Congress extremist, falls on deaf ears in the States and makes no appeal whatever to their rulers, 34

${ }^{31}$ Brallsford, p. 130 .

32Ibid. , pp. 14-15.

33Aundh, in the Deccan area of south-central India. 34 ire hontmorency, p. 76. 
The official British view of paramountcy was that it would lapse upon withdrawal, not devolve upon successor governments. The principalitles would become completely Independent with the choice of acceding to either dominion or of remalning independent. The rulers themselves held this view:

The States demand that without their own agreement the rights and obligations of the Paramount Power should not be assigned to persons who are not under its control, for instance an Indian Government in British India responsible to an Indian legislature. 35

The Moslem League leader, Mohammed Ali Jinnah, 36 indirectly supported this interpretation when he stated that a state's ruler possessed full power of accession to whtchever dominton he preferred with no obligation as a result of geography or devolution of sovereignty. 37 Nehru, speaking for Congress, refected the theory of lapsed paramountey and Insisted that the people of the states, through plebiscites, should possess the ultimate power of accession:

And here let me make it clear that it has been our policy all along that where there is a dispute about the accession of a state to either Dominion, the decision must be made by the people of that

\section{${ }^{35}$ Ib1d.. p. 96.}

36Mohammed Al1 Jinnah, 1876-1948, the Quald-E-Azam (Great Leader) of Indla's Mosiems and a lawyer by profession, Jolned the Moslem League after differing with the policles of the Indian National Congress. He participated in the London conferences of 1930-32 which led to the Act of 1935. In 1940 Jinnah announced the Moslem goal of an Independent state. In 1947 he became the first governor-general of Pakistan.

37Alice Thorner. "The Kashmir Conflict," Uiddle East Journal. III (January. 1949), p. 18. 
State. 38

The controversy remalned somewhat academic until, in June. 1947, the Bxitish cabinet announced that the June, 1949 withdrawal deadline would be anticipated by ten months. Problems of partition, paramountcy, and accession became Imnediate. Religlous rlots broke out in the Punjab and Bengal, two provinces scheduled to be split in the partition. The boundarles of the new dominions were traced according to a hastlly drafted partition plan and, while native Indian administrations began to exercise governmental functions, the princes were presented with an Instrument of Accession which provided for union with the appropriate dominion on defense, external affairs, and communications only. The majority of states soon ratifled accession treaties but the two largest, Kashmir and Hyderabad, asked more time in which to reach a decision.

Following August 15. Independence Day for the new dominions of Pakistan and the Indian Union. Kashmir's Hindu maharaja played and falled at statecraft. Lord Louis Mountbatten, 39 wille st1ll viceroy of a united India, had Journeyed to Srinagar but had been unable to persuade Sir Harl SIngh to accept union with elther dominion. In August Kashmir concluded a standstill agreement with Pakistan, providing for

${ }^{38}$ Jawaharlal Nehru. Independence and After (New York: John Day, (950), p. 57.

${ }^{39}$ Louis Mountbatten of Burma, Ist Viscount, 1900a grandson of Queen Victoria, was educated at Cambridge and soon thereafter began a military and naval career. He was supreme allied commander in southeast Asia, 1943-46; viceroy of India In 194\%; and f1rst governor-general of India in 1947 and 148 . 
continuation of economic and administrative relations on a pre-1ndependence basis, and began to negotiate a similar pact with India. But the time for expedients was running out. Moslem peasants in the districts of Poonch and Muzaffarabad were rest1ve, Refugees from the horrors of the Punfab massacres fled across the border into Jammu, carrying with them the hates and fears of communal bloodshed. Despite the standst1ll agreement, the necessary supplies were not forthcoming from Pakistan. The Kashmirl government took vigorous measures to counteract outside pressure:

In quick succession all voices in Kashmir pleading for accession to Pakistan were silenced; newspapers vere censored or shut down, journalists were interned, and finally the Kashmir State Assembly was prorogued to prevegt further criticlsm of the State Government. 4

When open revolt erupted among the Moslem peasants of Poonch and Muzaffarabad, the maharaja, in a final attempt to prevent the toppling of his throne, released She1kh Abdullah and empowered him to negotiate with Karachl and New Delh1. Jinnah Inflexibly demanded that Moslem Kashmir join Moslem Pakistan. 41 Nehru's reaction was confused, handicapped as he was by his previous assertion that the people, not the ruler, should declde the accession of a state.

In October the Pakistanl press reported the establishment of an Azad (Free) Kashmir provisional government at

$$
40 \text { Alice Thorner, "Conflict," p. } 21 .
$$

${ }^{41}$ Lef. sit. At Lahore in September an agent of Sheikh Abdullah was informed that Pakistan would not support an accession plebiscite unless the conference voted solidiy for Pakistan. 
Rawalpindi in West Punjab and various Moslem organlzations began warning the maharaja not to accede to India. The Kashmiri government countered by speeding work on a new road connecting Jammu with Ind1a's East Punjab. Pakistan protested the "brutal" suppression of the uprising among the Moslems of Poonch and Kashmir replled with detalled list of charges agalnst Pakistan, Including econpmlc blockade and infiltration of armed ralders. 42 On October 21 , the Pakistani prime minister. Liaquat AlI Khan, ${ }^{43}$ rejected the accusations and again warned against accession to India.

The following morning large armed bands crossed the Paklstani border Into Kashmir and selzed the frontier town of Muzaffarabad on the road to Srinagar. The Azad Kashmir government staged a dramatic reappearance. It identifled the ralders as Azad troops and began issuing communlques from Pulandri in western Kashmir:

The united will of the people has overcome the organized violence of the ruler's armies and he and his so-called PrIme MInlster have fled from Kashmir and will perhaps soon flee from Jammu as well. The Provisional Government entertains sentiments of the utmost friendliness and good will toward 
the neighboring dominlons of India and Paklstan.

The question of the accession of Jammu and

Kashmir to elther dominion can be decided only

by a free vote of the people in the form of a

As the ralders, later identifled as Pathan tribesmen

from the Northwest Frontier Province, neared Srinagar, the maharaja sought ald from New Delh1. Negotiations resulted in the accession of Kashmix to Ind1a on October 27, although the agreement spec1fically stated that the union was to be regarded as conditional until settled by a referendum. ${ }^{45}$ within hours Indian troops were on the way to Srinagar by alr to prevent the fall of the city. In accordance with a commitment reluctantly made by the maharaja. Shelkh Abdullah was asked to head an emergency administration.

Accession transformed Kashmir's difflculty into an open clash between Indla and Paklstan. Moslem spokesmen termed the maharaja's action "treachery" wh1le the Pak1stanl government refused to recognize the union:

In the opinion of the Government of Pakistan, the accession of Kashmir is based on fraud and violence. The sending of Indian troops to Kashmir under cover of its accession further intensified and inflamed the feelings of the tribes. 46

The prime minlster of the Northwest Frontiex Province declared that Kashmir rightfully belonged to Paklstan and appealed to "every Moslem In Paklstan to prepare to face the situation pp. 18-19.

${ }^{44}$ The New Yerk Times, October 25, 1947.

45 Sc officlal Becends, 3rd Year, 227th Meeting.

${ }^{46}$ The Neir Yerk Itmes, October 31, 1947. 
created by Inda's Invasion of Kashmir."47

New Delhi's view vas equally uncompromlsing. Although final settlement was conditional upon a plebiscite. accession was valld. Kashmir thus had become an integral part of iucuia defended by Indian troops and the Invasion of the state was a violation of Indian territory. In mid-iNovember Nehru announced that India possessed evidence proving that the entire affalr had been organlzed by the Pakistanl governnent:

They helped the tribesmen. - to collect, they supplied them with lorrles, with petrol and with officers. They are continuing to do so... It is obvious that no large body of men and armed groups coild cross. Pakistan territory without the good w11l, connivance and active nelp of authoritles there. It is impossible to escape the conclusion that the raids on Kashmir were carefully planned and well-organized by Paklstan authorities with the deliberate object of selzing the state by force and then declaring accession to Pakistan. This was an act of hostility not only to Kashmir but to the Indian Union. 48

Before the advent of winter severed land communication between Kashmir and India. Indian troops had cleared the Vale but the Azad government and its adherents retained control of areas near the Pakistani border. They continued to receive supplies and it was reported 49 that in addition to tribesmen

$$
\begin{aligned}
& 47 \text { Ibid.. November } 26,1947 . \\
& 48 \text { Ibid.. November } 26,1947 . \\
& 49 \text { Ibid.. January } 29,1948 . \text { The source of this report }
\end{aligned}
$$
was Russeli $K$. Haight, a 25-year-old ex-GI from New York who served two months as a brigadier general in the Azad forces. Indian representatives repeatedly referred to Halght's testimony during the Security Council debates on Kashmix. 
and Kashmirls, the forces consisted of Pak1stani natLonals and some regular Pakistanl troops-on leave, Karachi said. New Delhi charged that the rolders retired to bases in Pakistan following large-scale sorties. Indlan forces could not drive the invaders from Kashmir without attacking these bases. To do so would create an international incident.

Both Indla and Pakistan professed a desire to reach a settlement but negotiations falled to produce an agreement, partially as a result of the fanatic and emotional political climates in both nations which precluded any compromise. Karach1, while admitting that the tribesmen had crossed Pak1stan to reach Kashmir, denled that offlclal Pakistani sources had or were alding them. And Pakistan would be bound by the result of a pleblsclte only after all forces. Indian as well as tribal, had been withdrawn from Kashmir. India had taken the position that a referendum was not possible until "order had been restored"--that 1s, not unt1l Indian troops garrisoned the entire state:

We have declared that the fate of Kashmir is ultimately to be declded by the people. That pledge we have given. . not only to the people of Kashmir but to the world. We will, not and cannot back out of 1t. We are prepared when peace and 1 aw and order have been estabilshed to have a referendum held under international auspices liketthe United Natlons. We want it to be a fair and just reference to the peopie and we shall accept their verdict. I can imagine no fairer or juster offer. 50

Pakistan's delicate internal balance made any move toward compromise extremely hazardous since the government's

$$
50_{\text {Nehru, p. } 59 .}
$$


control over the wild tribes of the Northwest Frontier, the provecateurs of the Kashmir incident, was tenuous to say the least. The tribesmen never had acknowledged an overlord-Mogul. Afghan, or British--and they were even less 11kely to surrender meekly to the demands of the new-born Pakistanl government. The British had exerted what control, through subsidies and punltive expeditions, as was necessary to prevent the tribes from ralding the citles of the Indus valley but otherwise had left the tribes much to themselves. 51 pak1stan could not maintain the high Britlsh subsidies, nelther did 1 possess sufficlent milltary strength to administer the tribes forclbly. Karach1 hoped that a common religion would bind the fathans to the new Moslem state. Kashm1r, presented as a Hindu conspiracy to oppress Moslems with the additional prospect of loot for the "liberators," could be of use in such a program. And there was always the possibility that if Pakistan curbed the tribes in Kashmir, they would turn on the rich citles of the Punjab:

If Pakistan is to prevent the tribes by force of arms from infiltrating into Kashmir, the area of conflict will extend, not diminish. Pakistan will have a major war on her hands in her own territory. Is Pakistan, then, to fight against the tribesmen on her own territory in order to help Ind1a's conquest of Kashmir and to prevent her people from foining Pakistan? 52

51 "pakistan and the Tribes," Bound Table, XXXIX (September, 1949). p. 332 .

52The New York Iimes, February 6, 1948. The quotation Is an excerpt from a letter written by Col. Majeed Malik, a member of the Pakistani delegation to the Security Council. 
The Indian case, saturated with the theory and the practice of International law, would not admit the applicability of such an argument.

Fanatically clinging to their contradictory views, the dominions moved toward war in the weeks Immediately following Invasion and accession. But the voice of Great Britain, rapidly fading to a whisper in Inoian political iffe, proved yet sufficiently audible to forestall an open clash. With Pakistanl and Indian armies st1ll officered largely by Britons, the supreme command of United Kingdom personnel in both forces rested with British Fleld Marshal Sir Claude Auchinleck, 53 who Informed Karachl and New Delh1 that Brit1sh officers would resign rather than be involved in "a fratricidal Indian confl1ct." S1multaneously Brit1sh officers were ordered not to particlpate In Indian operations in Kashmir. But war, averted in October, threatened in December. The quarreling dominions, discouraged by the futility of bllateral negotlatlon, began to look for another imethod through which to achleve a settlement.

\section{III}

Neither Karachi nor New Delhi overlooked the possibility of a third party contributing its good offices. That this party might be the Comonwealth of Nations was, however,

53 Fleld Marshal S1r Claude Auchinleck, 1884- has devoted his mi.itany career to the East, serving in the Punjab, Egypt. Aden, and Mesopotamla. He was commander of Brit1sh Middle Eastern forces. 1941-42; In India. 1943-47; and of Indian and Fakistanl forces in 1947. 
unacceptable to Nehru:

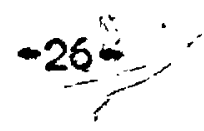

The Commonwealth might have been considered as some kind of a superior body which sometimes acts as a tribunal. or judges, or in a sense supervises the activities of its member nations. that certainly would have meant a diminution in our Independence and sovereignty. If we had once accepted that principle. Therefore, we were not prepared and we are not prepared to treat the Commonwealth as such or even to bring disputes between member nations of the Commonwealth before the Commonwealth body. 54

But on November 3. Nehru suggested that the promised plebiscite might be conducted "under international auspices $11 \mathrm{ke}$ the United Nations. "55 One week later. the Azad government proposed that the United States or the United Nations send observers to Kashmir to "testify to the Justification" of the struggle agalnst the Hindu maharaja.56 On November 17. Llaquat All Khan publicly favored asking the United Nations to send representatives. 57 Yet despite epparent agreement on the acceptability of the United Nat1ons. Indla's unilateral communication to the Security Counc1l roused Pakistan to expressions of violent chagrin.

On January 1, 1948 the Indian government Informed Counc1l President Fernand van Langenhove ${ }^{56}$ of Belgium of the

54 Nehru, p. 274.

${ }^{55}$ The New York Iimes. November 3, 1947.

56 Ib1d.. November 9, 1947.

57 I31d. November 17, 1947.

58 Fernand van Langenhove, 1889-, has been Belgium's permanent representative to the UnIted Nations since 1946. A former delegate to the League of Nations, he represented Belgium at the Untted Nations Conference on International Organization in 1945. 
existence of a dispute covered by Article $35^{59}$ of the United

Nations Charter:

A situation now exists. . owing to the aid which invaders, consisting of nationals of Pakistan. - .. are drawing from Fakistan for operations against Jammu and Kashmir, State which had acceded to the Dominion of India and is a part of India. - . The Government of India request the Security Council to call upon Pakistan to put an eni immediately to the giving $6 f$ such assistance, which is an act of aggression against India. If Pakistan does not do so, the Government of India may be compelled, In self defence, to enter Pakistan territory, in order to take military action against the invaders. 60

Van Langenhove immedlately urged both governments "to refrain from any step Incompatible with the Charter and liable to result in an aggravation of the situation. ." 61 On January 3. Pakistan replied that its case would be presented to the Counc1l by Foreign Minister Sir Mohammed Zafrullah Khan, 62 The inftial presentation of arguments was scheduled for January 6.

Two approaches to the dispute were open to the

59 Section 1 of Article 35 states that: "Any member of the United Nations may bring any dispute, or any situation of the nature referred to in Articie 34, to the attention of the Security Council or of the General Assembly." Article 34: "The Security Counc1l may investigate any dispute, or any situation which might lead to international friction or give rise to a dispute, In order to determine whether the continuance of the dispute or situation is likely to endanger the maintenance of international peace and security."

$60_{\text {SC }}$ offictal Records, 3rd Year, Supp. for Nov.. 1948, S/628, p. 139 .

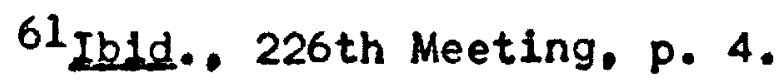

62 sir Mohammed Zafrullah Khan, 1893- has been Pak1stanl minister of foreign affairs since 1947. He served as president of the hioslem League in 1931 and on the viceroy"s counc11. $1935-41$. 
Counc1l. It might accept the Indlan point of view that the issue was purely one of international law and that consequentiy the Council should function as a judicial tribunal. An affirmative decision on the validity of the Indian charges would probably result in branding Pakistan as an aggressor. Or the Council might ignore the technicalities of formal relations among nations and recognize that, no matter which side the rules favored, there existed a situation in which both parties held an understandable interest; a satisfactory solution would have to be one that was acceptable to both. Solution of the Kashmir question, of great importance to the parties immediately concerned, would be of scarcely less significance to the Security Council itself. An answer would indicate that the council might yet be able to function successfully in a situation relatively uncomplicated by great power rivalry, that, if given the opportunity, it might be able to function as had been intended when the outline of an international security agency had been traced. The New Yerk Imes noted this aspect of the dispute:

If the Big Five can agree on a proper procedure, perhaps for the holding of a supervised plebiscite, the councll's prestige, badly damaged by the vato controversy, may be repaired. For the Council's purpose, as outilined in the Charter, is not to quarrel but to settie quarrels.63

${ }^{63}$ The New York Iimes, January 4, 1948. 


\section{CHAPTER II}

\section{COMPLAINT, COUNTER-COMPLAINT}

The Kashmir question made its initial appearance on the Security Council agenda on January 6, 1948. Five meetings and seemingly endless debates later, on January 20, the Counc1l had sketched a pattern for future action. The shaping of an approach to the problem could be discerned in procedures adopted for consideration of the question, the votes on and significance of two resolutions, and the attitudes of the Counc1l members themselves. States represented on the Counc1l were Argentina, Belglum, Canada, China, Colombia, France, Syrla, the Ukralnian Soviet Socialist Republic, the Union of Soviet Soclalist Republics, the Unlted Kingdom, and the United States. The first indication of alignments, or lack of such, followed Pakistan's request, on January 6, for a two-week postponement to permit better preparation of 1ts case. Only Farls el-Khouril of Syria gave Pakistan full support. The remalning Council members were elther noncommittal or displayed marked uniformity in opposing a delay in excess of one

1Faris el-Khour1, 1879-, entered the Syrian government in 1918. Prime minister during 1944-45, he attended the San Francisco conference in 1945 and has participated in several Arab League congresses.

$$
-29-
$$


week. Succeeding meetings bore out this first impression of a Council attitude relatively uncomplicated by great-power rtvalry.

When the Counc1l turned to consideration of the Indian complaint, it found a case rigidly bound to the theory and practlce of international law. Indla called attention to the existence of a dispute endangering international peace and security, a dispute engendered by Pak1stan's alleged aid to the Invaders of Kashmir. The "facts" of the situation led to certain "indisputable" conclusions:

(a) That the invaders are allowed transit across Pakistan;

(b) That they are allowed to use Pakistan territory as a base of operations;

(c) That they include Pakistan nationals;

(d) That they draw much of their military equipment, transportation and supplies (includIng petroil) from Pakistan; and

(e) That Pakistan officers are training. guiding, and otherwise actively helping them. 2

Paklstan's attitude in refusing to negotiate on these points not only was unneutral. "but constitutes active aggression agalnst India, of which the State of Jammu and Kashmir forms a part."3 International law sanctioned entry of Faklstan by an Indian armed force in order to deal with the invaders.

United Nations Security Council official Becords, Third Year, Supplement for November, 1948, S/628, p. 142.

3Loc. clt.

4Theorists in International law support India on this point. Oppenheim states that self-defense, coupled with an element of necessity, has long been considered adequate just1fication for a violation of the rights of another state. when. - a State is informed that a body of armed men is being organized on neighbouring territory for the purpose of 
However, the possibllity that such action might result in open hostilitles with Pakistan caused India to turn to the United Nations. In such a situation, the Security Counc1l would be justifled in calling upon Pakistan:

(1) To prevent Pak1stan Government personnel, milltary and civil, from participating or assisting in the invasion of the Jammu and Kashm1r State:

(2) To call upon other Pak1stani nationals to desist from taking any part in the fighting In the Jammu and Kashmir state;

(3) To deny to the Invaders: (a) access to and use of 1ts territory for operations against Kashmir, (b) military and other supplies, (c) all other kinds of aid that might tend to prolong the present struggle. 5

The Pakistani reply, submitted to the Council on January 15. relled more upon emotion than upon law in constructing case. Rather than aiding the invaders. Pak1stan had done and was dolng everything within its power "to discourage

a rald into its territoxy, and when the danger can be removed through an appeal to the authorities of the nelghbouring country, no case of necessity has arlsen. But if such an appeal is fruitles or not possible, or if there is danger in delay, a case of necessity arises, and the threatened State is Justified in Invading the neighbouring country and disarming the intending raiders," L. Oppenheim. International Law, A Ireatise, ed. H. Lauterpacht, Vol. I, Peace $77 \mathrm{th}$ ed.. London: Longmans, Green and Co.., 1948), pp. 265-66. Brierly concurs. "A state, like an individual, may protect itself agalnst an attack, actual or threatened." J. L. Brierly. The Law of Nations, An Introduction to the International Law of Peace (4th ed., Oxford: Clarendon Press, 1949). p. 291 .

Jessup states that in such a situation. "the incidental or consequent infringement of the rights of another state is excused, although the other state may be legally privileged to resist." Each state is entitled to judge in its own cause the "necessary degree of Immedlacy and urgency" without reference to an international authority. Philip C. Jessup. A Modexn Law of Nations (New York: Macmillan, 1948), pp. 163-64.

s/628, p. $\frac{5 \mathrm{SC}}{143}$ officlal Becords. 34d year, Supp. for Nov.. 1948 
the tribal movement by all means short of war. 16 while it might be possible that "a certain number" of tribesmen and persons from Paklstan were alding the Azad Kashmir government as volunteers, ${ }^{7}$ It was certainly not true that Pak1stan was an active party. Granted that a situation prejudicial to peace did exist, Kashmir, however, bas but portion of this dispute. an important element but one that could not be isolated. In this greater dispute, India was gullty on all counts--genocide for complicity in a Sikh plan to exterminate the Moslem population of East Punjab following partition; aggression for forcibly occupying Junagadh and several smaller states which, although HIndu-populated, had acceded to Pak1stan; and host1l1ty toward Paklstan for fallure to implement agreements on civision of the military, financial, and industrial assets of the former Indian government. 8 Kashmir was but the culmination of an Indian policy almed at the destruction of Pakistan. Accession had been obtained through "fraud and violence" after the maharaja failed in his attempt to suppress a legltimate uprising against his autocratic government:

On 15 August 1947. Jammu and Kashmir State like

s/646. p. 68 .

${ }^{6}$ gC offictal Becords, 3rd Year, Supp. for Nov.. 1943,

7 Westerners in the sub-continent reported that Pakistani authorities "continued to countenance the recruitment. training, transport, and equipping of tens cf thousands of tribesmen for service in Kashmir." Alice Thorner. "Issues," P. 177 .

8Agreement had been reached in Lecember, 1947, but India withheld delivery of certain supplies, claiming that they might be used against it in Kashmir. 
other States was free to accede or not to accede to either Dominion. It entered a standst111 agreement with Pakistan. - This was, however, only a device on the part of the Maharajah to gain enough time within which to create conditions which would furnish him with a plausible excuse to call in the forces of the Indian Union so that. after trampling down all popular opposition with their help, he might be ablo to accomplish his desire of acceding to the Union of India; thus putting upon the latter the respogsibillty of dealling with his rebellious people.

Pakisian requested the Council to, first, call upon Ind1a to cease its aggressive tactics and to implement the partition agreements, and second, to appoint a commission which would investigate the charge of genoclde, arrange evacuation of Junagadh anu other states, and bring about a ceasefire in Kashmir. The latter would entall:

- - the withdrawal of all outsiders, whether belonging to Pakistan or the Indian Union. .; steps for the establishment of an impartial and Independent administration. . .; and a pleblecite to ascertain the free and unfettered will of the people. - as to whethefo the State shall accede to Pakistan or to Indla. 10

Although the Security Council noted recelpt of the Pakistani document--and there were numerous references to it during the ensuring debates--the counter-complaint cild not become immediately a part of the agenda, a fact which was to create some confusion durling a later stage in the discussions.

The Counc1l began its consideration of the dispute in a routine fashion by seating the representatives of India and

${ }^{9}$ se offlelal Becerds, 3rd Year. Supp. for Nov., 1948, S/646. pp. $80-81$.

10Ib1d.. p. 68. 
Pak1stan--ne1ther state was member of the Counc1l--according to the provisions of Article $31^{11}$ of the Charter. With 1ts second procedural step, the Council adopted an approach to the problem which it maintained through four-and-a-half years. Actual negotiations were to be carried on in informal meetings between the parties with the Council president as rapperteur. The Counc1l would act only when the results of these conferences were reported to it in official session.

As two documents, the Indian and Pakistanl complaints, had opened consideration of the dispute, so two officlal papers marked the conclusion of this initial period. The first Belgian resolution, adopted January 17, was scarcely more than a rewording of Van Langenhove's wires to the governments In December. 12 However, the final paragraph, although initiating no action on the part of the Counc1l, was to be of unforeseen significance some months later, for Indla and Pakistan were requested:

- . to Inform the Counc1l immediately of any materlal change in the situation which occurs or appears to either of them to be about to occur while the matter is under consideration by the Council. and to consult with the Council thereon, 13

\section{Art1cle 31: "Any Member of the United Nations} which is not a member of the Security Council may particlpate. without vote. in the discussion of any question brought before the Security Counc1l whenever the latter considers that the interests of that Member are specially affected."

12 see page 27.

${ }^{13}$ SC Official Becords, 3rd Year, 229th Meeting. $5 / 651$. p. 121 . 
The resolution was approved with nine votes in favor-Argentina, Belgium, Canada, China, Colombia, France, Syria, the United KIngdom, and the United States--none opposed, and two abstentions-the Ukralnian Soviet Soclalist Republic and the Union of Soviet Socialist Republics.

With adoption of the second Belgian resolution, on January 20, the Counc1l established a definite basis for further action:

A. A commission of the Security Council is hereby estabifshed, composed of three members of the United Nations, one to be selected by India, one to be selected by Pakistan, and the third to be designated by the two so selected.

B. The Commissiun. . shall act under the authority of the Security counc1l. . . It shall keep the Security Council currentiy informed of 1 ts activities and of the development of the situation. function:

C. The Commission is invested with a dual

(i) To Investigate the facts pursuant to Article 34 of the Charter;

(2) To exercise. . . any mediatory influence likely to smooth away difflculties, to carry out the directions given to it by the Secur1ty Council; and to report bow far the advice and directions, if any, of the security Councll have been carrled out.14

The commission was to base its activities on India's complaint and on Pakistan's counter-complaint, which had extended the scope of the dispute beyond the question of Kashmir alone. However, consideration of the additional controversies introduced by Pakistan was to take place only "when the SecurIty Council so directs." The vote on this resolution dupli-

14 SC Officlal Records, 3rd Year, 230th Meeting, 5/654, pp. $130-31$. 
cated that on the flrst Belgian draft while a Soviet-sponsored motion to postpone final consideration pending further arguments was defeated with two votes in favor--the Ukrainian Soviet Sociallst $R=$ public and the Union of Soviet Socialist Republics--against nine opposed--Argentina, Belgium, Canadạ, China, Colombia, France, Syria, the United Kingdom, and the United States.

\section{II}

The second Belgian resolution culminated a serles of impassioned debates in which the Indian and Pakistani spokesmen, Gopalaswami Ayyangar ${ }^{15}$ and S1r Mohammed Zafrullah Khan, found themselves in violent disagreement on five basic points. First was the general approach to the problem. Ayyangar saw the issue as primarily one of International law, a question of whether or not Pakistan had violated its international obllgations as a result of its activities on behalf of the insurgents in Kashmir. Since India regarded the validity of accession as unshakable. Indian activity in the state was clothed in an impeccable legallty:

We desire only to see peace restored. . and to ensure that the people of Kashmir are left free to decide in an orderly and peaceful manner the future of theif state. We have no further interest. . Everything that we have done has been in discharge of our legal.

15N. Gopalaswam1 Ayyangar, 1882-, has been India's mintster of transport and rallways since 1948. His career of leglslative and executive service began in 1905. when he entered the Madras civil service. Ayyangar was Prime Ninister of Jammu and Kashmir from 1937 to 1943. 
constitutional, and moral responsibilities and obligations. 16

Pakistan, on the contrary, was guilty of the most flagrant violations of obligations among nations not only in not preventing but in actually abetting the tribal invasion of Kashm1r, which constituted a hostile act against India. Ientatively assuming the martyr's role, Ayyangar promlsed that India, whose motives were above reproach, would do its utmost to avold a conflagration although war might be forced any day by the "compelling necersities" of the military situation. Zafrullah Khan fully agreed on the danger of war but suggested that it hinged less upon compelling military necessities than upon the threat of "direct military attack" upon Pakistan by India. The Fakistanl representative looked more to an uncertain international equity than to the. Iet,ter of the law of nations in establishing a cace for Pakistan. While In no sense responsible for any transgression of the rights of either India or Kashm1r. Pak1stan refused to countenance the trampling of the desires of the Kashmiris beneath so-called international obligations. Pak1stan also deslred only an opportunlty for the people of Kashmir to make a free cholce:

We do not differ over theoobjective as stated. We desire that peace be restored; we have repeatedly sald that flghting must stop at once and that means must be taken to stop 1t. However, we differ over the definition of what you call peace and what we call peace. what you call order and what we call, qrier. what to you is law and what to us is law. 17

16 Sc Officlal Records, 3rd Year, 227th Meeting p. 28. ${ }^{17}$ SC Offictal Records, 3rd Year, 229th Meeting, p. 113. 
The matter at issue concerned illegal Indian suppression of a legitimate rebellion, suppression supposedly justifled by a fraudulently achleved suzerainty, rather than Pakistani or tribal disregard of law.

The second major controversy arose as a result of divergent views on the facts of accession; specifically, which nation had attempted to pressure Kashmir into submission. The picture was quite clear and uncomplicated for Ayyangar at least. On August 15, 1947 Kashmir, which had been an independent state in treaty relations with the Brit1sh Crown but enfoying no international existence, became free to decide whether to accede to one or the other dominion or to remain independent. The Kashmirl government Immediately began negotiating with both India and Pakistan. Admittedly. India was interested in Keshmir, both strateglcally and economically; "nevertheless, we have at no time put the slightest pressure on the state to accede to the Indian Dominion, because we reallzed that Kashmir was in a very difficult position."18 Not unt1l the eve of accession did Indla assume an active role. Then, after reports of disturbances had been followed by the news of a full-scale lnvasion. India felt compelled to respond to the state government's appeal forcaid. In order to give a legal basis to Indian operations in Kashmir. It had been necessary for the state to accede to India but the accession agreement clearly stipulated that this union was

\footnotetext{
18sc officlal Becords, 3rd Year, 227th Meeting. p. 13.
} 
conditional unt1l "order had been restored" and the people of Kashmix had been given an opportunity to ratify the maharaja's action:

I would invite. . attention. . to the highprincipled statesmanship characteristic of the Goveinment of Ind1a. - The acceptance of the accession was urged upon the Government of India by the leader of the most influential popular organlzation In Kashmir. It was clear to my Government. - that peace in Kashmir could never be restored or maintained without the support of the people. Sheikh Abdullah. - pressed for accession as earnestly as the Ruler. - hlmself. . On the question of accession the Government of Indla has always enunclated the policy that in all cases of dispute the people of the State concerned should make the decision. 19

Ayyangar launched a frontal attack, challenging

Zafrullah than to produce an equally noble Pakistanl record. He doubted that this could sincerely be done for Pakistan's maneuvers had been all too obvious. Economic blockade and repeated threats had constituted Pakistan's consideration of Kashmir's delicate situation:

The events. - cannot be explained away as a fortuitous comblnation of circumstances. A closer examination would reveal to any impartial body of men that there was a definite method, a galculated plan, which was belng followed. 20

Zafrullah Khan Ignored Ayyangar's challenge, retreatIng Into a bitter denunclation of India's "considerate" att1tude toward Kashmir. He wondered how 1 t could be believed that India, admittedly aware of Kashmir's strategic and economic possibilities, had not been aware of what was

$$
\begin{aligned}
& \text { 19tojd. p. } 20 . \\
& 20 \text { Ibid.. p. } 14 .
\end{aligned}
$$


contemplated with regard to accession, "that they did not try to Influence 1t." 21 The known fact that following his release from prison. Sheikh Abdullah had journeyed to New Delhi, presumably for conferences on accession terms, would seem to Indicate that Indla had been urging accession to itself for some time prior to October 26. But "it has unfortunately become a hab1t with the Government of India simply to deny whatever they find is inconvenlent elther to deal with or to answer, " 22

The true plcture of the "economic blockade" was of a slightly different hue than the version presented by Ayyangar, continued Zafrullah Khan. Supplies falled to reach Kashmir as a result of the general Punjab disorders, for as far as Delh1, transportation was at a standst111:

Consequently, there was a.shortage of supplies everywhere. It was not that the Pak1stan Government was unwilling to fulfill its part of the standstill agreement, but they were unable to do so owing malniy to these idisturbances. . 23

And If anyone were guilty of non-cooperation, it was the maharaja. Geography, economics, and the wishes of his people polnted toward accession to Pakistan, yet he favored India and sought to solve the problem by k1lling, Jailing, or expelling "a million or so" of his Moslem subjects. Pak1stan had agreed to discuss supply difficulties but heard nothing more on the matter from Kashmir. Since the preliminary demand for a

22 Ibid.. p. 105.

${ }^{23}$ SC official Becords, 3rd Year, 228th Meeting. p. 80. 
conference had been met, "there was no reason to ask for any outside assistance. 24

Ayyangar side-stepped further wrangling on the issue of pre-accession pressure, basing a fresh attack on Pakistan's activities once large-scale strife broke out in Kashmir. The Indlan approach on this point was uncompromising. Only with Pakistani ald could the tribesmen have achieved such considerable success; only by crossing Pakistani territory could they have reached Kashm1r. 25 Ayyangar offered the Counc1l several selectlons from Iridia's dossier on Pakistan--evidence that the tribesmen possessed modern weapons whlch "could only have come from Pak1stan military depots"; 26 "rellable" information that the prime minfster of the Northwest Frontier Province functioned as the chlef organizer of the rebel forces at Peshawar and that a number of major Pakistanl citles were used as tribal bases; and the obvious military fact that tactics employed by the raiders indicated that they were being trained and led by professional soldiers. It was, said Ayyangar, damning picture.

Anyone famillar with the Northwest Frontler would

24Lee. eit.

${ }^{25}$ During the f1rst months of the dispute, even the most heated Indian protests held to the semi-fiction that the trlbes had come ithrough but not from Pakistan. Not until repeated representations had fafled to bring from Pakistan the slightest concession to the view that tribal activities were 1 liegal did India directly accuse Pakistan of complicity. Allce Thorner. "Conflict," p. 29.

${ }^{26}$ SC efficial Recerds, 3rd Year, 227th Meeting, p. 22. 
know that the tribes, In addition to manufacturing weapons, had always been In the habit of accumulating large stores of arms by means "legitimate as well as 111 egltimate," countered Zafrullah Khan:

- One of the matters to which attention has been invited by the Pakistan Government. . . Is the failui of. . Indla to hand over to. . Pak1stan. - Its due share of military stores. Pakistan is woefully short of its quota, much less could it supply anybody out of it.. To pretend that the Pakistan Government is supplying them when the covernment of India knows it has withheld. . military stores is to add insult to infury. 27

Any British offlcer who had served on the frontier could testify that the tribesmen were in no need of training in milltary tactics or in the use of small arms. Lastly, if Pak1stani military personnel were operating in Kashmir, they were Poonch1s on leave and therefore on their own time:

If, when they go home on leave, these officers or men find that their people are being massacred or persecuted, and if some of them take a hand in whatever is going on, ilt is nevertheless not a case of allowing them to go on leave in order to take part in the flghting. . They are expected to say. "My brother may have been killed, my father may have been killed, my wife may have been raped and my children butchered. but I am not a nember of the Pakistan forces and must not retaliate." That kind of thing might be expected of angels but it cannot be expected of human beings. 28

The question of which government bore the blame for fallure to resolve the dispute through bilateral negotlations was the third major clash between the Indlan and Pakistanl 107-08.

275C efficlal Recerds, 3rd Year, 229th Meeting, pp. 28 Ib1d., p. 109. 
interpretations of the sltuation. Ayyangar again cast Indla In a role of altruistic nobllity, for India, seeking only a reasonable settlement in a friendly spirlt of "glve and take," had made repeated attempts to reach agreement, only to be rebuffed by Pakistan. Not unt1l the military situation had so degenerated that Indla's own peace and security were threatened had New Delhi chosen another course:

Negotiations finally broke down as a result of the attitude adopted by the Pakistan Government in declining to do what, under any view of rlght international conduct, it is its obligation to do. - Settlement would have been reached but for the intransigeance and the lack of adequate confidence and courage. in dealing with their own people, which the Government of Pakistan have unfortunately exhibited in this connection. 29

Quite the contrary interpretation was presented by Zafrullah Khan. Each time the Pakistanl government advanced proposals, the Indian government insisted that anything relatIng to Kashmir must be approved by She1kh Abdullah's admin1stration, a position wholly unacceptable to Pak1stan since It "prejudges the whole question of the plebiscite."30 And each tIme Pak1stan had suggested that the question be referred to the Unlted Nations, India had argued that, since Pakistan was not a legitimate party to the dispute and the ralders were not state, the United Nations could do nothing apart from sending observers. Zafrullah Khan concluded with a well-aimed thrust at the Indian charge of non-cooperation

${ }^{29}$ SC Offlcial Becerds, 3rd Year, 227th Meeting, p. 11. 30 sc offictal Becords, 3rd Year, 229 th Heeting, p. 93. 
by asking, why, if Indla was so interested in joint action. It had hot Informed Pakistan in advance that Indlan troops were to be moved Into Kashmir rather than walting until the "occupation" was a falt acconodi:

Were they not willing at the very least to not1fy the Government of Pakistan that the landing of troops in Kashmir was intended? There was no opportunity for discussion and no opportunity to partake of joint action in order to arrive at a settlement. 31

Unable to agree on an interpretation of the dispute, Zafrullah than and Ayyangar were similarly at odds on a fourth point--the action to be taken by the Security Counc1l. St111 steeped in the maxims of the cult of Grotlus. Ayyangar expounded the Indian view of right and law. Paklstan had violated 1ts International obligations and the Council should "use Its undoubted influence and power" to correct this situation by calling upon Paklotan to cease forthwith all ald and enoouragement of the anti-government forces in Kashmir. The dispute had arisen as a.result of such Pakistanl activity; once it had ceased, there would be no further disagreement.

This was neither the source of nor the solution to the difflculties as Zafrullah Khan viewed them. Kashmir wad the result of years of oppression of the lioslen population by the maharaja's government. The spark for this long-stored fuel had been the maharaja's deslre to accede to Indla. The result had been an understandable uprising of the people, in sympathy for whom the tribesmen and some Pakistani nationals

${ }^{31}$ sc efftetal Becoras, 3rd Year, 225th Meetin, p. 84. 
had offered aid, A bad situation had been made infinitely worse by the maharaja's "treacherous" accession to India and the "occupation" of Kashmix by Indian troops. The only solutIon was to order all outsiders to withdraw from the state so as to permit the people to decide their own fate:

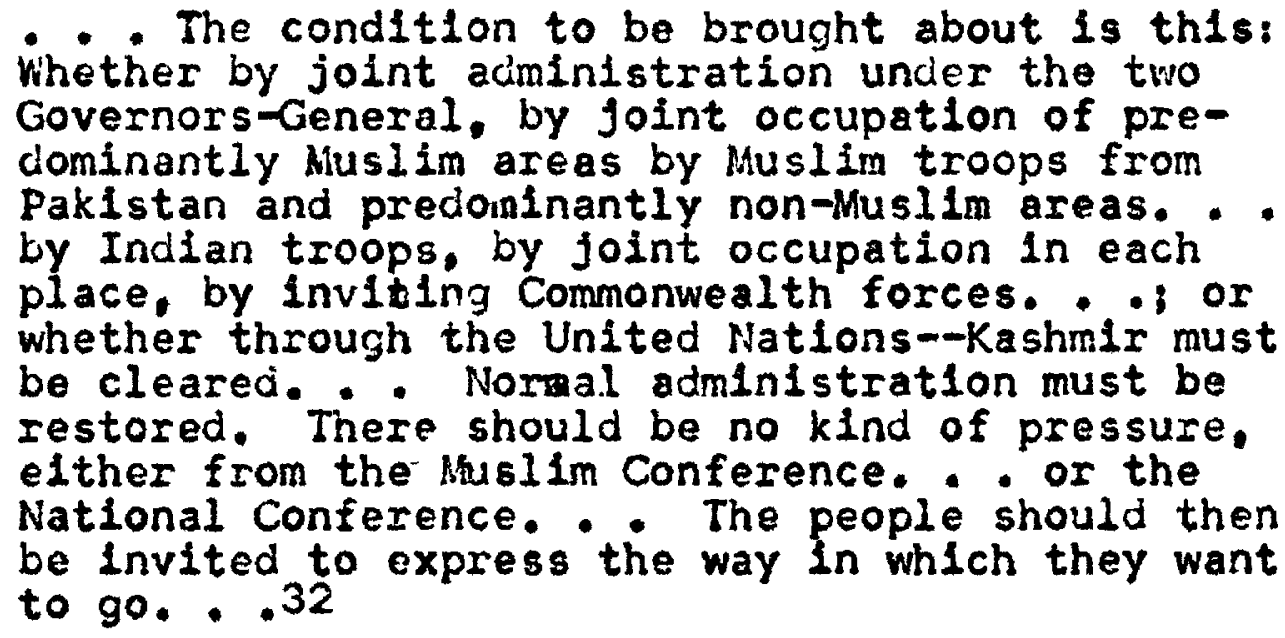
The fifth and, at this staga of the discussions on Kashmir, the most important agreement between the tuo advocates concerned the slgniflcance and scope of the dispute. Pakistan saw it as one facet of a much broader problem, a facet that could not be dealt with apart from the whole. India's view was that "the subject-matter of reference is 1 imited to the dispute in Kashmir. . . "33 Kashmir was a problem by 1tself, but vaguely related to the extraneous matters introduced by Pakistan. Discussion of adcitional 1ssues at this point would only further Impede progress toward a settlement while if Kashmir were considered by Itself and a settlement achieved,

32sc efficlal Recerds, 3rd Year, 229th Meeting, p. 120. The question of Commonwealth troops, which passed unnoticed at this point. was to assume some significance at a later stage. 33 ge offictal becoris, Jrd Year, 227th Heting, p. 23. 
tension between the two states would be eased and the other questions could be more readily resolved:

We hope to be able to convince the Security Counc1l that once we have dealt with the Kashmir question. there will probably not be anything of substance which will divide India and pakistan to the extent of endangering international peace and security. 34

Introduction of the second Belgian resolution, establishing the commission, provoked controversy on this point. Zafrullah Khan argued that reference to Kashmir should be omitted from the resolution's title to permit the commission full latitude in considering ali points raised by the Indian complaint and the Pakistani ccunter-complaint. At this point, Ayyangar selzed upon the fact that the Pakistani representation had never offlcially appeared on the agenda, thus the resolution and Council consideration at the moment were limited to Kashmir alone:

idon The Securlty Council can pass this resolu-
agenda. with regard to the item entered on the
are Investing this commission today with jurls-
diction to deal not only with matters connected
with the Bammu and Kashmir situation, but also
with matters outside that situation. . 35

Zafrullah Khan agreed that the language of the resolution referred directly only to Kashmir but insisted that the commission's powers should be broad enough to embrace all matters disturbing relations between the dominions and of which the Council was seized. "Irrespective of the fact that

\footnotetext{
${ }^{34}$ Sc official Becerds, 3rd Year, 230th Meeting, p. 136. 35 Ibid. p. 132 .
} 
discussion was proceeding at the moment only with regard to one of them."36 The Counc1l compromise, omission of direct reference to Kashnir with the understanding that it would nevertheless be considered before any attention was given to other 1tems, was accepted althoggh not applauded by both parties.

Although the statements of the Indian and Paklstani representatives consumed the major portion of these meetings and discussion among the Council members was consequently brlef. some Indication of the members' approach to the problem was evident. The prevalling attitude was neutrality with certain individuals openly volcing this view while others remalned largely noncomittal, their sentimento appearing only during the three votes. As previously mentloned, only Faris el-Khourl of Syrla appeared openly to favor one party.

The Counc1l member placed in the most difficult position in this dispute between two members of the Commonwealth of Nations was PhIlip Noel-Baker, 37 United KIngdom secretary of state for Commonwealth relations, who had been accredited as the UnIted Kingdom's speclal representative to the Council during consideration of the Kashmir question. As

\section{Ibid.. p. 134.}

37Phil1p John Noel-Baker. 1889- a Member of Parl1ament since 1936. Served in the Labor government from 1946 to 1951. Noel-Baker's background in internat1obal affalrs includes membership in the British delegation at Versallles in 1919. service with the League of Nations Secretariat and Assembly, and particlpation on the Executive Commission of the United Nations Preparatory Committee in 1945. 
was to be expected, Noel-Baker maintalned a scrupulously neutral attitude. Repeatedly he suggested compromise on major disagreements and urged the parties to seek agreement themselves in the out-of-Council conversations. The most outspoken delegate was Dr. Jose Arce ${ }^{38}$ of Argentina who voted with the majority and pursued a neutral policy but displayed an attitude all his own. Where the British attitude had been concillatory, almost appeasing. Arce reprimanded both India and Pak1stan. Nothing that the United Nations Charter contained no definition of aggression, he reminded Ayyangar and Zafrullah Khan that definition, contalned in the Rio pact, ${ }^{39}$ existed among the American states. Argentina would hold as the aggressor whichever dominion committed actions facling under this definition. Although approving the second Belgian resolution. Arce was disappointed at its weakness for he understood that the Council had been establ1shed "for the purpose of flnding a speedy solution for

$38 \mathrm{Dr}$. Jose Arce, 1881- , surgeon, medical educator, and writer, was appointed permanent Argentine delegate to the United Nations in 1946. Arce's government career began in 1903 and in 1945 be represented Argentina at the United $\mathrm{Na}$ tions Conference on International Organization, taking a leading part in the attack upon the great-power veto.

${ }^{39}$ Article 9 of the Inter-American Ireaty of Reciprocal Assistance states: "In addition to other acts which the Organ of Consultation may characterize as aggression, the following shall be considered as such: (a) Unprovoked armed attack by a State against the territory, the people, or the land, sea or air forces of another State; (b) Invasion, by the armed forces of a State, of the territory of an American State, through the trespassing of boundarles demarcated in accordance with a treaty, judiclal decision, or arbitral award, or, in the absence of frontiers thus demarcated. Invasion affecting a region which is under the effective jurisdiction of another State." 
any situation liable to compromise world peace and secur1ty."40 Yet after lengthy debates and several meetings, the Council did 11ttle but "appeal to these two governments to be calm and sensible." Arce did not suggest another approach. In only one instance, dicussion on the second Belgian resolution, did sharp controversy arise among the Council members themselves. Andrel Gromyko ${ }^{41}$ of the Soviet Union did not care for the structure of the commission. Theoretically a Counc1l creature, it would really be quite independent of the Counc1l and "would act without any reference to the latter, as the connexion between it and the Security Council would exist only on paper."42 Th1s would be the regult of establishing a body whose members were not necessarily represented on the Security Council. If a commission was to be created, let it be composed of states on the Counc1l so that it would be obvious that it was the Council and not an outside agency investigating the dispute.

Alfonso Lopez of Colombla took exception in curtly reminding Gromyko that the Council's goal was to settle the dispute, not to ientangle it in technicalities. All legal

${ }^{40}$ SC Officlal Records, 3rd Year, 229th Meeting, p. 124.

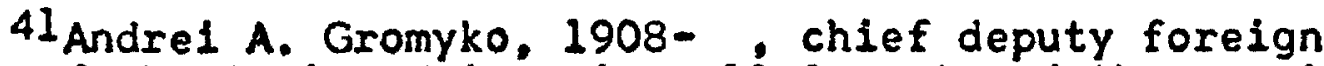
minlster of the Soviet Union since 1949, entered the commissarlat of forelgn affalis in 1939. He has served as Soviet Counselor at Washington, D.C.; minister to Cuba; and ambassador to the United States. Gromyko was in the Soviet delegation at San Francisco in 1945 and was permanent representative to the United Nations from 1946 to 1948.

42SC Officlal Becords, 3rd Year, 230th Meeting, p. 140. 
means of achieving this goal should be considered:

It seems. . It $1 \mathrm{~s}$ only too clear that, as they themselves have begun to establish the basis for an agreement in the appointment of the proposed commission, we should in turn be only too glad to accept the principle of this initial step. 43

Although Gromyko reiterated his view that the commission was not an agent of the Counc1l "either in form or in fact." the remalning members unanimously endorsed Lopez's view,

\section{III}

All too soon it was to become evident that the significant results of Initial Council consideration of the Kashmir question merely delimited the arena for future battles. But despite the brief duration of the optimism engendered by the accomplishments of this period, the five meetings were far from wasted tIme. A relatively flrm basis for future action had been established. The broad princlple of a pleblscite as the ultimate determinant of Kashmir's alleglance was never at issue between the parties and with Council acceptance, it became, for the greater part of four-and-a-half years, the factor upon which hinged all attempts to achieve a settlement. A first step, based upon this principle, had been taken with the creation of a commission charged with bringing about conditions favorable to a plebiscite and with supervisIng the eventual vote itself. And a Council approach toward the entire problem had been tacitly adopted.

435c Offictal Becerds, 3rd Year, 229th Meeting, p. 
The parties themselves had clearly outlined their positions. India underlined each item in its indictment of Pakistan with the maxims of international law, taking its stand on a case based upon three presumptions: (1) the accession of Kashmir to India was valld; (2) Pakistan, in abetting insurgents against the legitimate authority of a friendly state was violating certain rights and dutles of members of the international community; and (3) Kashmir was a problem by itself and should be considered onits own merits, not in relation to other situations. In these circumstances, the Counc1l's course was clear. Pakistan should be ordered to cease its activities in Kashmir, thus allowing India to restore order in the state and to remove the threat to peace. That the Indian case was handicapped by Immersion in legal theory was obvious. India's aims might be legitimate and understandable but they were scarcely furthered by Insisting that an issue Involving the fear, pride, and lives of men must be treated as textbook problem in law. Practicalities, no matter what theory might say, demanded that Pakistan be regarded as legitimate and vitally interested party. Pract1calitles, in an international community where judgments could be enforced only through cooperation or superior force, ruled out a satisfactory solution on the basis of Council "orders". But India's devotion to theory was fanatic and was to obstruct, for long months to cone, the concessions and compromises necessary to bring peace to Kashmir.

The fakistand case adroitly side-stepped the legal 
1 ssues raised by India and, beneath a flimsy interpretation of the facts in the case, rested upon emotion and moral right. For the record, Pakistan offered a legal position based upon four points: (1) the disturbance in Kashmir was a legitimate revolt against an autocratic government; (2) foreign elements In the state were neither alded nor offlclally sanctioned by Pakistan; (3) accession was fraudulent and therefore Indian troops were operating 1llegally in Kashmir; and (4) the situatIon was compounded of many factors and could not be resolved wlthout practical action on all issues of the broader controversy. The interpretation of accession was shaky. The replies to the Indian charges and evidence of aid were not quite convincing. The justification for ralsing additional matters in dispute to the importance of Kashmir was weak. But Pak1stan's practical approach to Kashmir itself--that it was of legitimate and vital interest to both. India and Pak1stan and both must participate in the settlement--found a favorable reception among the council members.

The resolutions, voting record, and comments indicated that, for all practical purposes, the Councll was united in seeking a solution acceptable to both India and Pakistan with no particular favoritism shown to either party. Soviet deviations, although difflcult to analyze at this early stage, hinted at lack of interest or opinion rather than an obstructlonist policy. It appeared that the Council had chosen a medlatory, not a judiclal, approach.

Pakistan was the greater beneficiary of this. 


$$
-53-
$$

development for 1 achieved recognition of equal status with Indla and could begin to shed its defendant's role. Indla, originally on the diplomatic offensive, found its carefully documented legal case all but ignored and its own actions about to be investigated. 


\section{CHAPTER III}

\section{A QUESTION OF PRIORITY}

\section{I}

The opening meetings of the second perlod of Council consideration, during which the agenda entry became the IndiaPakistan Question, seemed to presage steady, if rot swift, progress toward a solution of the dispute. On January 22, Van Langenhove was able to report that Ayyangar and Zafrullah Khan were agreed in princlpte on the prerequisites of a settlement. But development of details with which to flesh the principles proved beyond the Council's capabilities. As discussion degenerated into deadlock, Ayyangar, dissatisfled with the "unfavorable trend" of the debates, requested adjournment in order to return to New Delh1 for consultation. The request was granted on February 12.

The meeting of February 5 was noteworthy for Shelkh Mohammed Abdullah's appearance before the Council. In a bitter denunciation of Pakistan, he outlined the latest chapter, dating from the partition of India, in the history of Kashmir. The state had been so maladministered that the flrst task was construction of a democratic regime, not accession. India had granted time for the reorganization of internal 
affairs but Pakistan had applied pressure:

Paklstan wanted to force us to a position of slavery. . I had thought that Hitler and Goebbels were dead. But what has happened in my poor country convinces me that they have transmigrated their souls into Pakistan. 1

The change in agenda, which Van Langenhova had made on his own authority, symbolized the basic disagreement at this polnt. Ayyangar protested that only through a formal vote could an 1tem on the agenda be altered once adopted. In effect. Council jurlsdiction should be limited to Kashmir alone. Zafrullah Khan reiterated Pakistan's thesis: Kashmir was but one facet of a complex situation, all of which must be considered in order to achleve a solution. Although the Council eventually approved the change. India was appeased with a promise that only after Kashmir had been dealt with would the Paklstani charges be considered. Thus, on January 22, the Jammu and Kashmir Question became the Iridia-Pakistan Question.

A distinct note of optinism was introduced when Van Langenhove reported the parties agreed on three points: accession was to be decided by a plebisclte; (2) conditions must ensure complete impartiality; and (3) therefore, the referendum must be conclucted under the aegis of the United Nations. If details to effect these principles could be agreed upon, Kashmir would cease to be a problem. Although no resolutions reached a vote during these

1The New York Iimes, February 6, 1948. 
meetings, six were introduced and remalned before the Counc1l at edjournment. A Belgian draft ${ }^{2}$ recognized that Kashmir's future must be decided through a referendum sponsored by the United Nat1ons. After India and Pakistan had submitted qualIflcations, the resolution was amended to provide that the commission should work toward "promoting the ceswation of acts of hostillty and violence" and should report to the Counc1l on the fulfilment of essential plebiscite conditions:

Such proposals shall include measures designed to ensure cooperation between the mllitary forces of India and Pakistan with a view. . to maintaining order and securlty in the future. 3

On January 29, Van Langenhove introduced additional resolutions calling for a pleblscite and cease-fire. The plebiscite draft ${ }^{4}$ was primarily repetitious verblage, again recognizing that a vote must be organized and supervised under the authority of the Security Counc1l. The cease-fire proposal stated that:

1. In the accomplishment of its functions, the Commission of the Security Council shall take into consideration that, among the duties incumbent upon it, are included those which would iend towards promoting the cessation of acts of hostility and violence, and which are of a particularly urgent character;

2 . In the pursuit of this aim, the Commission shall use every diligence to ensure that its mediatory action be exercised without

${ }^{2}$ Sc official pecords, 3rd Year, 236th Meeting, p. 265. ${ }^{3}$ Sc offictal Records, 3rd Year, 236th Meeting, p. 269. 4sc effleial Becerds, 3rd Year, 237th Meeting, 5/661, p. 285. 
delay. 5

In the fourth document, the Counc1l recelved the flrst indication that India was not pressingly interested in an Immediate plebiacite, an Impression more than borne out in the ensutng months. On February 3, Ayyangar suggested a resolution in which the Securlty Council would concentrate on getting Pakistani-aided forces out of Kashmir and

- . that the Commission of the Councll shall, among its duties, regard as particularly urgent the promotion of measures intended to bring about as expeditiously as possible the cessation of fighting and other acts of host11ity. . .

Plainly, India was interested in discussion of a pleblscite only after a cease-fire had been arranged.

\section{A resolution submitted on February 6 by General} McNaughton ${ }^{7}$ of Canada, then Counc 11 president, urged cooperatIon among India, Pak1stan, and the Counc1l and listed seven princlples of just settlement: (1) cessation of hostilities; (2) withdrawal of all non-Kashmirl irregular armed forces; (3) maintenance of order by the forces of both Indla and Pak1stan until accession was determined; (4) withdrawal of all p. 286 .

${ }^{5}$ Sc Official Becerds, 3rd Year, 237th Meeting, S/662,

${ }^{6}$ SC Officlal Records, 3rd Year, 239th Meeting, p. 326.

7 Andrew George Latta McNaughton, 1887- , has served Canada In military and civil capacities since 1909. Commander of the 1st Army Overseas, 1940-44, he was minister of defense, 1944-45, and at present is chairman of the Canadian section of the Canada-U.S. Permanent Joint Board on Defense. General McNalighton has been a delegate to the League of Nations and Commonwealth conferences and was permanent Canadian representative to the United Nations, 1948-50. 
forces when such was accomplished; (5) return of refugees and release of political prisoners; (6) establishment of conditions necessary to a falr plebiscite, including an interim administration; and (7) a plebiscite under authority of the Council at the earliest possible date.

The final document, a Colombian resolution introduced on February 11, followed McNaughton's proposals in calling for withdrawal of tribal forces and an Interim administration and in addition:

The Commission of the Security Council shall be composed of representatives of five Members of the United Nations, designated as follows: one to be selected by Indla, one by Pakistan, as already provided. . and three by the security council. . . 8

\section{II}

The alteration of the agenda entry was the first of four points to provoke prolonged controversy between the Indian and Pakistan representat1ves. Ayyangar again displayed his devotion to technicalities by noting that the previous meeting had adjourned with the understanding that the Counc1l would meet again to consider "this question," obviously referring to the existing entry, the Jammu and Kashmir Question. Since that was the matter to be discussed, the change was unauthorlzed and invalid. Indla was not unwilling to discuss other issues but 1t was important that there be no change in agenda at the present time:

8sc offictal Records, 3rd Year, Supp. for Feb., 1948, S/671, p. 27 . 
What I have been trying to persuade the Securlty Council to accept is the point that we are now engaged in debating only the Jammu and Kashmir question, with all the background that anyone may bring into it. . I am now concerned with being satisfled that the debate in which we are now engaged will confine itself to the Jammu and Kashmir question.9

Kashmir alone would be like "a sentence torn out of Its context," countered Zafrullah Khan. No matter what might be the fine points of Counc1l procedure, consideration of all the questions could not be avolded:

I am not concerned with the technicalitles of the question. So long as it is deemed that all these questions are before the security Council and on its agenda, I do not insist that a particular hiading be applied. . The point which I desire to have stablished clearly is that the Security rouncil is now selzed of a situation between india and Fakistan and that that situation has many facets, of which Kashmir and Jammu is only one.10

Although the Counc1l compromise appeared to meet the demands of both Ayyangar and Zafrullah Khan, It was clear in later debates that neither party had abancioned or intended to abandon 1ts position on this question.

The second clash ranged over all previous charges and counter-charges. M. C. Setalvad, ${ }^{11}$ who spoke for India on Januany 23, attacked Zafrullah Khan's accusations as estab-

'Sc officlal Becords, 3rd Year, 231st Meeting, p. 161.

10Ibid., pp. 159-160.

11M. C. Setalvad, 1884- , has been with the Indian United Nations delegation since 1947. Advocate General of Bombay in 1942, he resigned in protest agalnst British policy in India. Setalvad represented India on the partition commission which traced the boundaries of India and Pakistan. 
lishing a record for "calculated venom. . Irrelevancy. . deliberate omission. - and clever distortion of facts. ${ }^{12}$

Complaints of Indian treatment of Moslems came from a government which had failed "woefully" to discharge its own obligations toward minorities. Nor would India countenance the charge of noncooperation:

It has been suggested. . that the Government of Pakistan was not informed of the intended dispatch of troops. My answer is that there was no need nor obligation to inform the Government of Paklstan of this dispatch of troops to the Kashmir State. The accession had made it a part of the Indian Union.13

Hastily deserting this wakk defense, Setalvad attempted to guide the debate back to the issue as India saw it. That issue remained whether or not, in reference to the invasion of Kashmir. Pakistan had disregarded its obligations to a friendly neighboring state. Pakistan protested that It was anxious to discharge its international dutles but was unable to prevent the tribes from entering Kashmir:

That 1s, I am sure the members of the security Council are well aware, no answer. A State cannot say that it is unable to restrain war11ke passage through its territory to others, and permit an Invasion of a neighbouring state. 14

12 Sc Officlal Becerds, 3rd Year, 232nd Meeting, p. 171. i3sc Qffielal Becerds, 3rd Year, 233rd Meeting, p. 223.

14Sc Official Becords, 3rd Year, 232nd Meeting, p. 186. Oppenheim supports Setalvad: "States ere under a duty to prevent and suppress. - Subversive activity agalnst forelgn Governments as assumes the form of armed hostile expeditions or attempts to commit common crimes against ilfe or property." Oppenhelm, pp. 260-61. 
Zafrullah Khan, again denying that Paklstan had alded the invaders, sought to minimize the importance of forelgn forces in the Kashmir disturbances. He quoted figures listing 60 per cent of the insurgents as native Poonchis, 35 per cent as iribesmen, and only 5 per cent as Punjabi Moslems, supposedly proving that strife in Kashmir was a legltimate revolt against the maharaja. 15

Still clinging fanatically to the legal approach, Setalvad prompted the third controversy by raising the question of the place of precedent in Security Council procedures. He called to the support of his contentions as to Paklstan's llability the findings of the comission in the Greek question:

The existence of disturbed conditions. . In no way relleves. . nelghbours of thelr duty under international law to prevent and suppress subversive activity in their territory aimed at another Government, nor does it relleve them of direct responsibility for their support of. . . guerrillas.16

Setalvad slipped in a graceful bld for Sovlet support by notIng that although the USSR had not concurred in the report. he was sure it was not because the principle was faulty under Internat Ional law but because the USSR was not convinced of the correctness of the commission findings. Evidence and

\section{An Indian White Paper of March 5, 1948 estimated, on} the basis of bodies recovered, that the composition of insurgent forces opposing the Indian army in Kashmir was 70 per cent Pathans and Moslems from Dir and Swat states, 20 per cent deserters from the Maharajah's state forces, 5 per cent from Poonch. " and 5 per cent Sundas." The New Yerk Ifmes. March 6, 1948.

16Sc Official Eecords. 3rd Year, 237th kecting, p. 298. 
precedent combined in a clear case for the judiclal-minded Indian. "If measures short of war fall to prevent the inf1ltration" of the tribesmen, It was the duty of Pak1stan "to resort to measures of war against these tribesmen."17 Admittedly "no authority" on international law, Zafrullah Khan was disinclined to carry on a lengthy discussion on the relation between the Kashmix and Greek situations. But he thought the comparison poor. Kashmir, unlike Greece, was a case of an allen oppressor ruling over a people "with whom he has nothing in common." W1th this brief appeal to the principles of humanitarianism over the maxims of law, he stepped around the concept of precedent and moved on to the "absurd" suggestion that Pakistan go to war with the tribes:

That 1s strange advice. . . when the object - 1s to bring about an immediate stoppage of the fighting. In ordex to bring about an immediate stoppage of fighting. . not only should this war in Kashmir continue between the people. . - and the Maharaja, but Pakistan should start a new war on the frontler with the tribes in the tribal area. 18

Such rldiculous references to unreallstic theory merely obstructed consideration of more important 1ssues, some of which had more practical legal aspects. One was the legalIty of Kashmir's "purported accession" to India, a question ralsed by Pakistan at the outset:

All . - allegations, even if they could be made out in fact-which is disputed--are based upon the assumption of the validity and legality

$17_{\text {Ibid., p. } 301 .}$

18 SC Official Eecereis, 3rd Year, 239th theeting, p. 347. 
of the accession of the State of Kashmir to India, which ralses. . questions of fact and questions of law. 19

To question the validity of the accession was incomprehensible to Setalvad, for Indla had been approached on behalf of both the people and the government of Kashmir and had then agreed only on the condition that the union be ratifled by a plebiscite. If accession were a product of fraud and violence, to Paklstan fell the blame. And even if the accession should be 1nvalid, "whlch we do not for a moment admit," Pak1stan would remain under certain international obligations:

The position would be that Kashmir has not valldly acceded to India: but it has not acceded to Pakistan at all. . By all the principles that govern international relations, Indla has the right to go to the aid of a legitimate Government, even if the opposition to that Government is from its own insurgent nationals. $\therefore$. A nelghbouring country. $\cdot$ has not the right to go. . to the help of insurgents against the constituted authority In a... State. That. . is a well understood principle in international law. 20

An Issue that was to remain an obstacle to a peaceful settlement for four years was the fourth point which engaged the advocates in full-scale verbal battle during this serles

${ }^{19}$ SC Offic1al Recerds, 3rd Year, 236th Meeting p. 274. 20Ibid., pp. 275-76. Oppenheim is not fully in accord, holding that a state may recognize as belligerents, and thus lawfuliy ald, insurgents if they succeed in controliing a part of a country, maintain a government, and conduct their own military operations. Th1s corresponds to thePakistail interpretation of the Azad government. But the question of exactly when such conditions legallze recognition, and ald, is dangerous and difficult to answer. "For an untimely and precipitate recognition. . Is an unlawful act, and it is frequentiy maintalned that such amount to intervention." Oppenhe1m, p. 124. 
of meetings. From the outset India and Fakistan had agreed on the necessity of a plebiscite but it now developed that they differed radically on the conditions under which that plebiscite should be conducted. The Indlan plan called for pac1fication of Kashm1r, then a referendum under the assplces of the United Nations. However, Sheikh Abdullah's administration was to remain as the state's civil authority.

We have to take the verdict of the people of a State which is now being governed by machinery which it has had for years. Kashmir. . . conducts its own administration. . The question 1s whether. . One can oust that machinery completely and put something which comes from outside in its place. I think that would mean an amount of encroachment on the ordinary soverelgn powers of any State, to which no State would be willing to agree. 21

Thus despite accession, Indla appeared to attribute many aspects of soverelgnty to Kashmir. Sheikh Abdullah himsolf attacked the concept of an interim government. Conceding that he was no longer impartial, he maintained that this fact would not affect his administration of Kashmir. In any event, the United Nations had no authority with which to displace a legal government:

Where are you going to get this neutral admin1stration? I say to you frankly that if you ask Almighty God to administer the State of Kashmix, I do not feel He will act impartially. 22

A neutral administration was prerequisite to Pakistani agreement on a plebiscite, retorted Zafrullah Khan. Judging

${ }^{21}$ SC Offleial Becords, 3rd Year, 239th Meeting, p. 329. 22The New York Imes. February 6, 1948. 
from certain remarks in which he had implied that referendum plans might be dropped, 23 Sheikh Abdullah's competence to conduct a fair vote was questionable. The Indian plan would not bring peace, although "it might bring suppression and a good deal of oppression." 24 Zafrullah Khan saw legal technical1tLes again obstructing progress:

It is entirely irrelevant today to inquire whether, juristically, the holding of a plebiscite for this specific purpose falls within. the domestic jurisdiction of the Maharaja or within international furlsdiction. . I beg to submit. . that, in order for the plebiscite to be free and unfettered, . the aiministration. . . must be impartial and neutral.25

This was to be the basis of Pakistan's interpretation of plebiscite conditions through four years of negotiations.

A question of priority shattered what hope remained that the disputants might early reach preliminary agreement. Indla stubbornly inslsted that consideration of detalled pleb1scite procedures should come only after hostllities had ceased:

It would be putting the cart before the horse If the Security Council.. - proceeded. . to deal with the question of a plebiscite which, If it $1 \mathrm{~s}$ in fact a matter for discussion and

23 "There may not be a referendum after the disasters at Baramula, Ur1, Pattan, and Muzaffarabad. The people may not bother about it any more." The New Yerk Iimes. November 12, 1947.

${ }^{24}$ SC Offletal Records, 3rd Year, 239th Meet1ng, p. 348. 25se official Recerds, 3rd Year, 240th Meeting, p. 354. 
deciston by this body, should come at the very
end.

For this reason, Ayyangar opposed simultaneous consideration of the Belgian plebiscite and cease-fire drafts. India's "concrete" cease-fire proposals had apparently been brushed aside; Instead, there is a draft resolution before the Security Counc1l which is. . Innocuous in the extreme."27 Acts of violence and hostility were being perpetrated every day; yet the comnission, which was not yet in existence, was advised to do something which would "tend" to "promote" the cessation of those acts. Certain amendments might make the drafts acceptable but no matter what action the Counc1l might take, the Indian goal would remain the same:

After flghting is stopped, normal conditlons are restored and everybody belonging to the State has returned to his home and land, we want conditions to be established with a two fold objective; first, the establishment of a system of self-government acceptabls to the people of the State and secondly, final settlement of the question of accession. 23

Far from agreelng with the dogmatic Indlan attitude, Zafrullah Khan belleved that an immedlate plebisclte agreement would automatically halt host1lities without tirssome invest1gation of questions of fact and of law:

Pakistan was and is willing to forego all these investigations if the one point on which the parties are agreed. . the question of the accession of the Kashmir State. . shall be

26sc Official Becords, 3rd Year, 236th Meet1ng, p. 272. 27 SC Officlal Recerds, 3rd Year, 237th Meeting, p. 294. 2850 effictal Becords, 3rd Year, 239th Weeting, p. 327. 
decided by means of a plebiscite, and if, in order to secure Its falrness and impartiality. the plebiscite is carried out under the aegis of the Security Council. 29

Despite continued discussion, the deadlock remalned unbroken. On February 10, Ayyangar summar1ly requested adjournment, assuring the Counc1l that India was not withdrawing the question from consideration. But as "the trend of opin1on. - seemed to Ignore the urgency and Immedlacy of a solution and to consider problems which could walt, "30 the Indian delegation hat concluded that the less immediate problems should be considered at leisure, In full appreclation of all factors Involved. The request pleased no one. Zafrullah Khan considered the situation too urgent to warrant postponement, particularly as Pakistan had other matters to take up. We do not know where we stand."31 But on February 12, the Council acceded to the request with the understanding that the delegation would return as soon as possible.

Shifts in sympathy among the Councll members had become evident as this serles of debates drew to a close. On the question of the agenda, there were varying views. Gromyko's thesis was that "only the Counc1l can delete any Item from the Council's agenda."32 Therefore, the Kashmir pp. $274-75$.

29 SC officlal Becords, 3rd Year, 236th Meeting. 30 Untted Nations Bulletin. IV (March 1, 1948), p. 193. 31 The New Yerk Itmes, February 12, 1948. 32sc offlclal Records, 3rd Year, 231st Meeting, p. 150. 
question was still the legal entry and would remain so until the Council decided otherwise, although he had no objection to including the Fakistani counter-complaint as a separate item.

Fast footwork on both siules of the issue characterized Noel-Baker on this polnt. At first he agreed "broadly" with the Indian contention that the question of Kashmir had precedence, although "we cannot cieny to the representative of Paklstan the right to ralse a matter which he thinks urgent." 33

But Arce was of a different persuasion, for if the Council attempted to deal with Kashalr apart from the other questions, the dispute might never be seitled and the Councll would be committing a "flagrant injustice" against the two dominions. All factors must be considered regardless of the fact that only one was officially before the Counc1l:

We must remember. . that this is not a court of justice but a political boly, which must be governed by fixed rules but cannot pay too much attention to trifling details of form, particularly when they do not Involve major questions of principle, 34

El-Khouri reached the same conclusion after following a legal route. HIs jucicial experience convinced him that, once a principal claim had been submitted to "any court of justice," the defending part was free "at any time" to submit a counter-claim relative to the original issue:

The representative of the United Kingiom did

33 IbLd.. p. 148.
34 Ib1d. . p. 150. 
not speak about the relationship between the claims. If he considered them not related to each other, his suggestion would be correct; but if he considered that they were linked to each other, then his proposal to have the claims discussed and decided separately would not be correct. 35

Apparently always willing to oblige, Noel-Baker reversed his fleld when he found Councll consensus opposed to his suggestion. After all, "the substance is what matters" and the members appeared to be agreed on the substance, which was that all the matters were on the agenda, directly or by Implication.

Oplnions on the question of priority of plebiscite or cease-fire followed a simllar pattern. Again Noel-Baker, not Inclined to take "dogmatic" view of the importance of either, attempted to place a kindly hand on the shoulder of each party. He saw merit in Immediate consideration of referendum procedures but "not at all because I an agalnst the view expressed by the representative of India that stopping the flghting is our most urgent task. I agree with him fully...36 Noel-Baker now belleved that the entire issue, from measures to halt strife to the staging of a plebiscite, was one problem. If confidence in a plebiscite could be created, a cease fire might automatically follow. As was to be expected, the Indian representative took violent exception to this position. Colncidentally, one meeting later Noel-Baker announced that he had changed his mind; he no longer felt it necessary to

35Ibid., p. 149.

36sc offichal Becerds, 3rd Year, 236th heeting, p. 282. 
to consider the plebiscite first.

El-Khourl and Axce agaln favored the Pakistani slde of the 1ssue. No question of prlority arose for cease-fire and pleblscite were interdependent, said El-Khouri. Further, he agreed with Pakistan that the tribesmen were no one's agents:

The tribesmen and the inhabltants of Kashmir are not responsible to anybody, and I do not belleve that anyone would have sufflcient control over them to issue a cease-fire order. . .37

And Arce jolned Zafrullah Khan on two points. He questioned the ab1l1ty of She1kh Abdullah's administration to conduct an Impart1al referendum and, In IIne with the Pakistani argument, regarded misrule by the maharaja as the basic cause of Kashmir's difficulties in arguing for the priority of a plebisclte:

It is worth while to remember the Latin proverb, which says sublata causa, tollitur effectus, or, in other words remove the cause and the effects will disappear. . If. . . we assure these human beings that they themselves will be able to declde thelr own fate freely. . I am sure. that they will lay down their arms, I am sure that the tribes will withdraw to thelr own territor1es.38

Warren Austin 39 of the United States followed NoelBaker in avolding commitment to elther India or Pakistan,

${ }^{37}$ SC Offlelal Becords, 3rd Year, 237th Meeting, p. 290. ${ }^{38}$ SC official Records, 3rd Year, 240th Meeting, p. 367.

39Warren Robinson Austin, 1877- , former Unlted States senator, was named United States special ambassador to the United Nations in 1947. His record in international affalrs includes membership on the Senate Foreign Relations committee and service as an adviser to American delegations at various inter-American conferences. He is credited with devising the Act of Chapultepec. 
although he did favor an Interim government for Kashm1r.

Elaborating upon this point, hhe gave indirect support to

India's position on the validity of accession. With accession the external sovereignty of Kashmir had been transferred to India. Therefore, India need not worry that the foisting of an Intarin administration upon the state would be a violation of international law:

Now here we see the external sovereignty of Kashmir and Jammu possessed, and exercised before us in this petition by India. A plebiscite is one of the conditions attending the accession and the grant of this part of the exercise of soverelgnty from Kashmir and Jammu to Ind1a. . If chis solution involves an interim government, Indla has full authority. 40

At one polnt Austin became extremely critlcal of the tone of the Indian case, which seemed to be requesting the Counc1l to "pull-off Pakistan" and let India "finish the Job" In Kashmir. He informed Ayyangar that the Counc1l was opposed to

${ }^{40}$ SC efflelal Becords, 3rd Year, 240th Meeting, p. 376. Austin is not quite in line with Oppenheim. If the relation of states, such as Kashmir, to the central government is considered to be in the nature of vassalship or Indian suzerainty. India possesses international guardianship but the state is independent internally. This is India's own interpretation. The institution of a new government, even if in pursuit of international obligations over which India possesses authority, would amount to a violation of the internal "sovereignty" of the state. "Suzerainty is by no means sovereignty. It is a kind of international guardianship. . In ever case in other States, since the suzerain absorbs these relations entirely, such vassal nevertheless remains a half soverelgn State on account of Its Internal Independence. . "Oppenheim specifically cltes the states of the Indian Empire as examples. The Instrument of Accession supposedly placed the states in the same position toward Indla or Pakfstan that they had enjoyed with respect to Great Britain. Oppenhein, pp. $170-71$ 
all fighting and definitely would not act as an ally of one party to the dispute. This was a further indication that, in the eyes of the Counc1l, Pak1stan had achleved equal status and rights with India in Kashmir.

Although T. F. Tslang4l of China believed that the obvious key to the problem lay in the plebiscite, he nevertheless managed to stay on the fence by noting ithat "on the other hand, unless we restore peace in Kashmir, such a pleblsclte would not be possible." 42 The best method of halting strife, sald Isiang, required Faklstan to use its Influence to keep the tribesmen from entering Kashmir and India to withdraw its troops progressively if the Pakistani appeal were effective. Th1s suggestion was to be echoed in later, more detalled, cease-fire proposals.

\section{III}

The debates which had opened on January 22 in an atmosphere of optimism closed on February 12 under a cloud of bitterness and despair. Far from fulfilling the high hopes of progress seemingly promised by acceptance of the second Belgian resolution, the discussions had only revealed apparcntly Irreconcileable differences on detalls in the implementation of principles relatively easily agreed upon. Yet

${ }^{41}$ Tingfu Fuller Tsiang, 1395- , at present permanent representative of China to the United Nations, was educated in the United States. A former professor of 3 istory, he cntered the Chinese aiplonatic service in 1936, serving as ambassador to the Soviet Union from 1936 to 1938.

42 se officind Becoris, 3xu Year, 237th iieeting. p. 209. 
the perlod was of considerable signiflcance to later developments. It indicated that achievement of a settlement would be an arduous and prolonged task and 1t witnessed emergence of a number of 1 ssues which were to increase in importance during the months to come. Disagreement concerning an interim administration and the priority of plebiscite or cease-fire was not easily to be reconclled. The genesis of future ceasefire proposals lay in Islang's suggestions and, In the Colomblan draft resolution, there lay a modification of the commission's structure which was later to be acted upon.

The six resolutions, which expired unenacted with adjournment, clearly demonstrated that the Counc1l, desplte Indla's attitude, planned to make the eventual plebiscite even more 1ts own concern than the question of who was legally at fault in Kashmir. Ayyangar may have been somewhat justlfled In his criticism of the circuitous route by which the Belgian resolution arrived at a cease-fire proposal but eventually he, like the Counc1l members themselves, would have to face the fact that the Council was not an International tribunal empowered to issue injunctions but must achieve its goals through mediation and the cooperation of the parties to a dispute.

The Indlan case remalned embedded in law, stressinc the legal aspect of all major issues, the validity of accession, an interim administration, and priority of plebiscite or cease-flre. There was as yet no indication that New Delh1 was prepared to compromise on any posint: 
The Counc1l is not concerned with whether or not the Maharajaw lawfully became the rule (sic) of the State, whether or not there is a moral administration in the State, whether or not the Maharajah 13 sovertign, and whether or not Kashmix, ias, legally acceded to Indla. The only issue is that Pakistan must observe its international obligations 3 and nust not support any outside raiders.

The suggestions that Pakistan go to war, If necessary, to fulf1l its obligations and that the Council rebtrain Pakistan in order to permit Indla to accomplish its aims In Kashmir were 111-advised in the extreme for they could only irritate those members of the Council sincerely working toward an end to hostilities.

The Pak1stanl stand, although st111 less legal-based than the Indian, called upon 1 aw in entering a stronger challenge to the validity of accession. This but indicated that Pakistan would do better to avold judiclal intricacles for the reasoning in this instance was weak. On the remalning 1ssues, an interim government and precedence of plebiscite of cease-fire, Pakistan continued to stress the practical aspects of the situation. The position that a cease-fire would be a relatively unimportant matter if only a plebiscite were Immediately guaranteed was somewhat extreme but not so annoyIng to the Council as Indla's seeming dismissal of the pleb1scite from Immediate consideration.

Council opinion, as a result of a number of rash Indian statements, the abrupt adjournment request, and Indian

43unlted Nations Bulletin, IV (March 1, 1948), p. 194. 
Intransigeance on the interim administration and plebiscite issues, had become more critical of New Delh1. Yet there was only slight deviation from the neutral attltude adopted In previous medtings. Rakistan had apparently added Arce to El-Khour1 in 1ts 11st of potential champlons, but Austin, Noel-Baker, and Islang rematned resolutely in the middle. other members were largely noncommital. And the Counc1l, in decisions on the agenda and on the plebiscite-cease-fire controversy, had more clearly defined its approach to the entire problem. It was, as Arce had stated, "not a court of justice but a political body" and it would seek a solution not through legal but through polltical means. Noel-Baker attested to the Counc1l's bellef that its role was mediatory:

Having heard the parties, I want, with equal understanding, with equal friendship.. for both, as a member of the Security Council. sharing our collective responsibility to mankind, to ask the question: What ought the Security council now to do? 44

Granted that officlally the Council remalned neutral, Pakistan could yet claim an advanco at the conclusion of the second serles of meetings. The alteration of the agenda was a major victory, although it remalned to be seen whether the Pakistani counter-complaints would assume much importance in the discussions, and, as a result of the uncompromising Indian attitude on an interim administration and a plebiscite and the impolitic request for adfournment, the Council was growing increasingly annoyed whth the Indian position.

${ }^{44}$ ce offictal Becords, 3rd Year, 235th heeting, p. 250. 


\section{CHAPTER IV}

\section{PARAGRAPH BY PARAGRAPH}

\section{$I$}

Kashmir again became a problem for the council on March 8, 1948. A recess of almost month duration had provided time for an alteration of the situation in Kashmir Itself and for considerable diplomatic activity in London and Washington, the two capitals now beginning to show the most concern over the dispute. On March 5, She1kh Abdullah had been appointed "state Premler at the head on an Interim popular government." 1 Previously he had merely headed an emergency administration while the pre-invasion prime minister continued as titular chief of the government. In addition, the maharafa had guaranteed a democratic constitution and a representative government for the state. And rumors that the United States and the United Kingdom had been seeking a new approach to the problem, perhaps a broadening of Sheikh Abdullah's regime sufflclent to win Pakistani approval, flooded Lake Success.

Hopes for progress during the third phase of Counc1l debates were not entirely misplaced for when discussion

The New Yerk Iimes, March 6. 1948. 
concluded on June 3 , a program for commission activity in Kashmir had been adopted by the Counc1l, and grudgingly accepted by New Delh1 and Karach1, and the United Nations Commission for Indla and Paklstan had been constituted. On April 23, Belgium and Colombia Joined Czechoslovakla and Argentina, previously selected by India and Pakistan respectively, on the commission. The United States became the fifth member on May 7 .

Of three resolutions introduced during the meetings, two, a six-power draft and a Syrlan-sponsored document, were approved. The former afforded the commission 1ts final structure and was essentlally a modification of a Chinese resolution which did not reach a vote. The draft ${ }^{2}$ submitted by Tslang provided for the withdrawal and denial of all aid to the tribesmen, then the progressive withdrawal from Kashmis of Indian troops not essential to the security of the state; the remainder should be stationed so as not to "afford any Intimidation or appearance of intimldation." India was to establish a plebiscite administration "with the sole and full authority to administer the plebiscite on the question of accession of the state." Further:

10. The Government of India undertakes to use its best endeavours to ensure that in the composition of the Interin Government of Jamnu and Kashmir provision is made for adequate representation of all major political groups in the state.

11. The Government of India agrees to $\$ 1699$, pp. $33-40$.

23c Offictal becords, 3rd Year, Supp. for March, 1948, 
appoint an official of high standing to be stationed in the State during the interim period, who shall have the power to cause to be fulfllled by the State Government all international obligations arlsing out of the present Articles of Settlement. 3

The commission, after observing the plebiscite, would certify to the Council whether it had been "really free and impartial." The six-power (Belglum, Canada, China, Colombia, United KIngdom, United States) resolution, later adhered to by France, Im1tated the Colombian draft of February 11 in the Increase of the size of the commission to five members. Pakistan was to persuade Insurgent elements in Kashmir to cooperate In cease-fire attempts and to secure the withdrawal of the tribesmen from the state. Indla was to withdraw its troops in stages when arrangements for a cease-fire becam effective and to inform the commission of the completion of each stage. Again, the presence of the remaining troops should not afford "any intimidation or appearance of intimidation." The plebiscite administration was to control state police forces:

If these local forces should be found to be Inadequate, the Commission, subject to the agreement of both the Government of India and the Government of Pakistan, should arrange for the use of such forces of elther Dominion as it deems effective for the purpose of pacification. 4

The Kashmirl government was to be broadened to Include representatives of all major political groups and the

\footnotetext{
${ }^{3}$ IbId., p. 340. p. 21 .

${ }^{4}$ sc official Records, 3rd Year, 286th Heeting, $5 / 726$,
} 
pleblscite adminlstration was to be granted all powers necessary for an Impartial referendum. Indian forces would be made avallable to assist the administration and a plebiscite administrator, nominated by the secretary-general of the United Nations, would be appointed by and serve as an official of the government of Kashmir. Further:

The Government of Indla should undertake to prevent, and to give full support to the Administrator. . In preventing any threat. coercion or intimidation, bribery or other undue influence on the voters in the plebiscite. . .5

India was to ensure that the Kashmirl government would guarantee civil liberties, release political prisoners, and permit the return of refugees. Lastly, the commission was to certify, at the conclusion of the plebiscite, that the vote had been "really free and impartlal." The counc1l voted upon each paragraph of the resolution. Belgium, Canada, China, Colombia, France, the United Kingdom, and the United States favored every provision while the Ukraintan Soviet Soclalist Republic and the Union of Soviet Soclallst Republics abstained on all. Argentina and syria abstained on those paragraphs which appeared to give Indla a greater voice in the pre-plebiscite administration than was accorded Pakistan. Final Council action occurred on June 3 following receipt of a comission request for forther instructions, particularly as to whether the group was to consider the items in the Pakistani complaint in addition to the situation in

$$
\text { S.bid., p. } 34 \text {. }
$$


Kashmir. The resultant Syrian resolution directed the commission to proceed "without delay" to the scene of the dispute "wlth a view to accomplishing in priority the dutles assigned to it $^{6} 6$ by the six-power resolution. Regarding Pakistan's counter charges, the commission was instructed:

- . further to study and report to the Securlty Counc1l when it considers it appropriate on the matters raised in the letter of the Forelgn Minister of Pakistan, dated 15 January 1948, in the order outlined in Paragraph $D$ of the resolution of the Council dated 20 January 1948.7

This order was: (1) the situation in Kashmir as set forth in the Indian complaint and in the Faklstanl reply and (2) the additional matters contalned in the Pakistanl counter-complaint. The resolution was approved with eight in favor (Argentina, Belgium, Canada, Colombla, France, Syrla, the United Kingdom, and the United States) and three abstentions (China, the Ukrainian Soviet Soclalist Republic, and the Union of Soviet Socialist Republics.).

\section{II}

Inttial arguments in the new serles of debates revealed no relaxation in the rigid Indian and Pakistanl positions after a month in which to reconsider attltudes. Ayyangar proclaimed hopes for an early settlement but repeated India's refusal to withdraw troops before the plebiscite, emphasizing that in no fashion would Indian forces be permitted to interp. 21 .

${ }^{6}$ SC Official Becerds, 3rd Year, 312th Meeting, $5 / 819$,

7 Lee. sit. 
fere with a "free and unfettered" referendum. Yet a neutral regime remained "unthinkable"; "it is not possible for Indla to yield on this point. 8

Zafrullah Khan used Indignation over India's failure to modify its position to mask the absence of compromise in the Pak1stani approach. A further protest was entered on the appointment of Sheikh Abdullah as premier of Kashmir, a falt accompli which would further impede a settlement for "no one" would accept as fair and just a referendum carried out by the "hand-picked" premier of the maharaja with the aid of Indian troops. For the record, Paklstan continued to demand Immedlate consideration of plebiscite procedures.

But the chill was relleved somewhat with the introduction of the Chinese resolution. Although this measure called for changes in the government of Kashmir and a reduction in the strength of Indian forces, Ayyangar was able to modify his previous position and to express guarded approval of the draft as "an honest, bona fide and fair attempt to settle the question." 9 St111, as a first step, the Council should order Pakistan to halt aid to the insurgents.

Zafrullah Khan was "bewildered" that anyone should expect the government of Paklstan to accept the Chinese proposal. The plan might reduce the more obvious forms of pressure on the voters but it could not prevent more subtle

\footnotetext{
8 The New Xerk Iimes, March 11, 1948. 9Ib1d., March 19, 1948.
} 
methods of coercion as long as Sheikh Abdullah remained at the head of Kashmir's government. The Shelkh had stated that he was willing to broaden his ministry by the inclusion of representatives of other political groups as long as all members of the government were loyal to the National Conference.10 The premier would not tolerate "disloyal and traitorous" elements. The Idea was obviously to establish one-party government and to rule out participation by both the Moslem Conference and the Azad Kashmir government.

The Chinese resolution had at least found Ayyangar not totally unsympathetic but the s1x-power draft drew his fire as well as Zafrullah Khan's. Ayyangar was not at all pleased to see that this draft, although based on Islang's, had been so twisted out of shape by compromise that practically every amendment of substance was "a definite worsening of our position, and constitutes a breach--in some cases, a violent one--In our fundamentals."ll Resolutely pecking at technicalities, he noted that although the Chinese version was not above crit1c1sm, it had possessed some happy features:

It avolded any unnecessary or Improper encroachment by outside authorlties on the sovereign powers exercisable in the State by the Jammu and Kashmir Government and by the Government of India within their respective constitutional spheres. It respected constitutional propr1eties in the relations which, in a federal

10 According to the Indian government, Abdullah's first ministry included a member of the Moslem Conference, one of five Moslems in a seven-member cabinet. The Kashmir Issue, p. 15 .

${ }^{11}$ se efflclal tieceris, 3ri Year, 235th Heeting, p. 6. 
structure, should subsist between the Government of India and the Government of a State which had acceded to India.12

Th1s was not so in the case of the six-power measure which appeared to provide for the complete displacement of the legitimate state government. And a most unsatisfactory feature was the scant consideration given the issue on which India had invoked Security Council Jurisdiction:

Short of obtaining an officlal declaration of war by the Pakistan Government and the use of their regular army openly for conducting milltary operations in Jammu and Kashmir, the flghters have been and are obtalning all other help and assistance on Pakistan territory. 13

It was not clear to Ayyangar whether the provision calling upon Pakistan "to prevent" the entrance of tribesmen and Pakistanl nationals into Kashmir carried a clear commitment on the use of Pakistani armed force if peaceful methods failed to halt this movement. "Unless this commlttment is unequivocal, the undertaking 'to prevent' is not of any practical value. .14

Zafrullah Khan was even less Impressed by the resolution. The fundamental problem was to determine the conditions essential to a successful pleblscite. Yet the draft concerned to a great extent the character of the insurgents. Deserting Kashmir altogether, Zafrullah Khan threw himself into an

$$
\begin{aligned}
& 12 \text { Ib1d. . p. } 4 . \\
& 13 \text { Ib1d. . p. } 6 . \\
& 14 \text { Ib1d., p. } 11 .
\end{aligned}
$$


hysterical and impolitic attack upon the Council. He saw in these "vague provisions" the result of much whisporing diplomacy:

If that is so, it would appear that at least some of the members of the Security Council seemed to have realized. . Witis a sense of sharp surprise, that the Security Council had for once let itself silp into a position of falrness and impartiality between two contending parties whtch might help to restore the United Nations a fraction of the prestige that It was so rapidly losing in the eyes of the world. They therefore beat a hasty retreat from position so unfamiliar and embarrassing and fraught with the possibility of such undesired consequences.15

If Pakistan were to persuade the tribesmen to withdraw, Paklstani troops must be permitted to operate in the battle areas in Kashmlr to supervise withdrawal. Yet the only troops provided for were Indian, which would encourage non-thoslcm elements in Kashmir, knowing that forces charged with malntaining order were drawn from their own side, to grow aggressive and repeat the horrors of the punfab. In short, all pre-plebisclte provisions seemed to be welghted heavily in favor of India.

Ayyangar, unfortunately, had not reached the same conclusion, although it was only right that arrangements should favor India. The union of Kashmir and India was legal; it existed at that moment and it would exist at the conclusion. of hostilities. It would oxist until and if a plebiscite went against India:

15Ibid.. p. 26. 
Until then, Pakistan has no constitutional position in Jamu and Kashmir; and we therefore put it forward as one of our fundamental contentions that, in regard to the arrangements which we make for the plebiscite uncier international auspices, there is no case for alfowing the intervention of Pakistan at any stage. If

Ayyangar resented the tendency of the Council to regard Indian forces in Kashmir as an army of occupation. India would not abdicate its "paramount duty" of defending Kashmir as long as accession lasted. Standing rock-solld on the legallty of the union, he attacked the resolution for falling to grant India a privilege ho must have known could never be accepted by Pak1stan:

When the whole of the state. . comes under one administration--and that, the administration of the State of Jammu and Kashmir--India's garrisons will need to be planted at her outer frontlers on the west of the Jammu and Kashmir State.17

Wrath consumed Zafrullah Khan with Indla's open espousal of such an extreme position, a position wholly unacceptable to Pakistan. India not only desired to be the sole judge of the validity of accession and of the constitution of the government of Kashmir but Insisted on Council aid In imposing a military regime upon the entire state to achieve what its own 11 legal efforts had been unable to accomplish. No matter, how, Indla might confuse the issue, the essence of the matter remained that accession was a question equally vital to both dominions, "and they are equally vitally

$$
\begin{aligned}
& 16 \text { Ibid., p. } 13 . \\
& 17_{\text {Ib1d. . p. } 14 .}
\end{aligned}
$$


Interested in its result." 18

Apparently no matter what its structure, Indla would consider no interim government which was not totally an Indian creature. The resolution provisions on this point may have been mild in the eyes of the Counc1l but they were too much for Ayyangar. Indla did not oppose the inclusion of certain outside elements in the present government. Yet the proposal to supplant that government with a special, coalltion admin1stration was out of the question, for such administrations were actually dangerous if brought into existence "at a time when the major political issue before the country is one on which those groups differ violently. 19

Zafrullah Khan was equally uncompromising on the other side of the 1ssue for he saw the continuance of the existing government, coupled with the presence of Indian troops in Kashmir, as unavoldably prejudicial to Fakistan. On these "two central crucial matters" Pakistan asked only an impartial fleld from which all suspicion of favoritism toward one party or the other had been removed. But, as the Pakistani spokosman correctly polnted out, the arrangements upon which India insisted would "influence the pleciscite in only one direction; there is no possibility of their influencing it in the other. 20

$$
\begin{aligned}
& 18_{\text {Ibid. . p. } 29 .} \\
& 19_{\text {Ibid. . p. } 14 .} \\
& 20_{\text {IbId. , p. } 30 .}
\end{aligned}
$$


Ayyangar's ultimate view was that the modifications

of the Chinese resolution embodied in the six-power draft so attenuated the former that Indla found acceptance impossible. Indla and Pakistan appeared to be "tarred with the same brush" In the Interests of bullding a council reputation for holding the scales even between the partles, an attitude Zafrullah Khan had just as vehemently criticized the Council for abandoning with the six-power measure:

India brought before the Security Council a plain, simple, stralghtforward, factually fool proof 1saue, and the action that we suggested the Security Counc1l should take was Inescapable. . Instead of taking that action earlier, Indla's complaint was placed in cold storage for nearly four months. - And at the end of it If all we are exhorted in appealing language, to agree to a resolution niggardly in its recognition of the merits of the matter, vague and indefinite in the wording of the action to be taken by Pakistan. And in the interpretation of that language the Security Council has gone even further and been apologetic to Pakistan for reminding it of its duty. India cannot, in honour, agree to this treatment of its case.21

At last the Indian and Pakistanl representatives found themselves in agreement, albelt of a negative variety, for Zafrullah Khan similarly opposed the resolution. However, certain amendments, which would actually amount to a drastic reversal of the intentions of the proposal, might make it acceptable to Pak1stan. Such alterations as granting Pak1stan the right to employ troops in Kashmir and reorganization of the government on the basis of equal representation of all major political groups would, in effect, transfer control of

\section{Ibici., p. 12.}


the state to the insurgent forces if the wording of the Pak1stani amendment were adopted:

The Government of the State shall forthwith be reconstituted so as to give equal representation to each major political group in the State - -y12., the National Conference, the Muslim Conference and the Azad Kashnir-which will $e a c h$ be invited to designate an equal number of responsible representatives to constitute a Council of Ministers. This Council of Ministers may choose one of its members to act as President, but in the allocation of portfollos it will be guided by the advice of the Commission. 22

The unusual spectacle of Indian-Pakistanl agreement, even though in opposition to the resolution, evidently convinced the council that at last a falr formula had been discovered, for each paragraph received the approval of a majority of the members. And a rereading apparantly convinced KarachI and New Delhi that the measure was not lquite so objectlonable as first supposed for although nelther government unreservediy accepted the resolution, both announced that they were willing to consult with the commission once it reached the sub-continent. 23

\section{Ibid. . p. 47.}

23 According to reports from New Delhi, the reception Ind1a would accord the commission might be less than heartfelt: "The Indlan press has begun to lay the ground work for the rejection of any recommendations that the commission may make unless they favor India. Dispatches from Kashmir make 1t plain that the pro-India Goverrment of Sheikh Abdullah is now unwilling to accept even an impartial plebiscite. . . It may be borne in mind that Indla and She1kh Abdullah, with Kashmir already in their hands, have nothing to gain and everything to lose so far as the United Nations Comission's work is concerned. . In a. . dispatch from Srinagar, Sheikh Abdullah is quoted as having said in a speech to. . . his $\mathrm{Na}-$ tional Conference party: 'Kashmif is our homeland and no forelgner has any right to interfere in our internal af airs" The New York It-ic... 16, 1948. 
Nelther Ayyangar nor Zafrullah Khan commented exteagively on the Syrian resolution for by that time, June 3, the commission had been constituted and had departed for India. However, Ayyangar remained opposed to any broadening of comission powers:

All I need say 15 that my Government wishes me to bring to the notice of the Security Council the fact that it is opposed to any extension of the powers of the Commission to cover ithese three additional charges, because it considers, first, that these ancillary charges have not been proved; and, secondly, that these charges do not constitute any alement of international importance which merits consideration by the Security Counc11. 24

The Pakistani oplnion was even more briefly expressed, returning to the theme that $1 t^{\prime}$ was the "totallty of relations between the two Dominions which constitutes a threat to International peace. . .25 consequently, it was but natural that the commission be instructed to investigate all facets of the dispute.

Neutrality remained the Council's byword. Austin of the United States again stepped forward as the champion of an Interim administration, provision for which was contained in both resolutions. However, he was not in sympathy with the Pakistani suggestion that all political groups in Kashmir should share equally in the government:

The draft resolution does not mean. . that each of the three political groups. . . should

24SC Officlal Becerds, 3rd Year, 312th Meeting, p. 19. 25 Ibld. p. 8. 
be given the right to designate an equal number of responsible representatives to constitute a Council of Ministers. It is not our thought that the predominantly Muslim character of the population. . . should be a criterion. . It is likewise not our thought that sny undue advantage should be given to one group merely because they hold the power at the present moment. The principle involved is that of neutralization of the Government in so far as the issue of accession is concerned. 26

Considered in its entirety, the $\$ 1 x$-power resolution was not a final solution, "not a determination of issues," said Austin. It was simply a method of aiding the parties to achleve a solution other than through a military decision. Noel-Baker similarly stressed the absence of any indictment in the resolution:

To my Government it is in no sense an award, a verdict, a judgment between the parties; it is a plan, a body of measures. . designed to stop the present fighting in Kashmir and to provide machinery for the falr and impartial plebiscite on Kashmir's future. . .27

In Islang, India found a faintly sympathetic volce during debates on the six-power measure. Although criticizing Ayyangar for his opposition, when the draft actually offered much that India asked. Islang agreed that the plebiscite, the "arch of the resolution," was Impossible without prior restoration of order. The proposal called for a reduction of Indian forces in Kashmir but he could not see that it denled India the right to enter the state again in self-defense if raids should reoccur:

26SC Offletal Records, 3rd Year, 236th Meeting, p. 25. 27 se effelal jecerds. 3rd Year, 284 th Meeting, p. 12. 
I maintain that if the provisions of the draft resolution were each executed in turn, the problem of defence would be a minor one, if $1 \mathrm{t}$ did not disappear al together. . But if our calculations should be wrong and if, suddenly, there should be large invasion, then what? . Nothing in this draft resolution impairs the inherent right of self-defence. 28

Arce continued to display a predilection for Zafrullah Khan's case, opposing all portions of the resolution which appeared to give India an undue advantage in the deployment of armed forces in Kashmir. And, with Zafrullah Khan, he argued that "speeches and proclamations" alone would not be sufficient to persuade the tribesmen to withdraw; Pakistan should be allowed "to make use of all the means at its disposal. - and among those means, the most frequently employed Is the use of pollce, of force."29 Pak1stanl troops should be permitted to operate in Kashmir.

El-Khour1 opposed the draft on two counts: (1) it unduly favored Indla and (2) since it did not meet the wishes of either party. the Council was making a futile gesture in approving a program which could not be implemented without the cooperation of Indla and Pakistan. He then struck at Indla with New Delhi's own weapon of law for he charged that although the resolution treated the political aspect of the problem satisfactorily, it Ignored the legal aspect, accession:

It would not be legally and judiclally correct ${ }^{28}$ Ibid. . p. 9.

${ }^{29}$ sc offielal Bocords, 3rd Year, 2E6th Neeting, p. 13. 
If we considered the accession as already havIng taken place, and that it cannot be modifled except by a plebiscite. I consider that, up to the present time, there is no accession of Kashmir to elther Dominion, because that accession which was proposed was not in conformity with the arrangements and agreement macie between the two parties, and it is not an arrangement with the people of Kashmir themselves whereby they have been given a chance for self-determination, an opportunity to declde their own fate. 30

He considered it "fair and just" that, in drafting the resolution, the Council should give both parties equal privileges in the plebiscite arrangements and thus abstained from voting on provisions which called for the use of Indian or Kashmirl state forces or offlcials and did not provide similar benefits for Paklstan or Azad Kashmir.

Discussion on the Syrian resolution added Guy de la Tournelle of France, for the moment, to Isiang as an Indian advocate. De la Tournelle thought the measure unnecessary and Implied that the Pakistani counter-charges did not merit investigation. Yet he would vote for the resolution since it would have an inconsequential effect on the commission's activitles, neither hindering nor alding them:

The fact that the Commission is given complete freedom to consider these questions does not at all mean that it will deal with them. On the contrary it will be free to disregard them without referring back to the Security Council, If it thinks that these questions do not const1tute a threat to peace.31

30Ibid., p. 4. El-Khouri was referring to the IndoPakistani understanding that disputed accessions would not be regarded as final until settled by a referendum.

${ }^{31}$ SC Official Becerds, 3rd Year, 312th Meeting p. 19. 
Tslang stepped forward openly in India's defense in this Instance, abstaining in the vote on the resolution. He feared that further instructions to the commission would obscure the most important issue, Kashmir, and attempted to persuade the Fakistani delegation to drop the charges in its counter-complaint. The implementation of partition agreements was a matter of administrative detail; no real infustice would be done to eithex party if the charge were dropped. The validity of the genocide issue was doubtful:

It would be wise if the representative of Pakistan would drop the question of genocide. . Bringing up that question here casts a certain siur on the Government of India. I do not think that the slur is deserved. . . and I do not think that the handling of that question by the Security Counc1l would really help to restoie better relations between the two Governments.32

Advice so close to the Indian case was understandably rejected by Zafrullah Khan.

\section{III}

The Counc 11 record from March 8 to June 3, 1948 was perhaps more encouraging, than that of any other single perlod during the dispute. The United Nations Commission for India and Paklstan, long promised and discussed, had at last been created and given a fairly detalled plan of operations. And desplte Indian and Paklstanl protests during the meetings, the home government had expressed quallfled willingness to cooperate with tha Council's agent once it began its task.

$$
32 \text { Ibid. . P. } 4 .
$$


If an International investigatory body were the answer to the problem of Kashmir, the Council had taken a long step toward a settlement. Yet already there were Indlcations that the comnission's future was not to be untroubled. India's unilateral action in the appointment of Sheikh Abdullah as Kashm1r's premler foreshadowed a tendency to act in Kashm1r without previous consultation with either the Security Council or Pakistan. The practical value of United Kingdom-United States mediatory activity was evident in the provisions of the Chinese and six-power resolutions covering an interim administration, the principle of which Indla reluctantly accepted. But such action had aroused Pakistan's resentment and even though diligent negotiations might persuade India to move toward compromise, results would continue to be nullified if Shelkh Abdullah could not similarly be persuaded to abstain from inflammatory statements.

The three resolutions, particularly the Chinese and s1x power drafts, bore out the Counc1l's determination to achleve a compromise political settlement rather than to hand down a Judicial declsion. Both resolutions appeared to be based on a practical analysis of the situation, recognizing Paklstan's right to a volce in any settlement but similarly noting that, until ocession was definitely invalidated, India enjoyed a legal status that could not be claimed in all honesty and sincerity by Pakistan. The Syrian resolution, in providing for the priority of Kashmir, effectively shunted the Pakistani counter-charges to the sidelines and $c a n$ be 
viewed only as a valueless sop to Pakistanl pride and honor, as De la Tournelle so obviously implied.

On the surface, the Pakistanl and Indian positions appeared to have remained firm but in reactions to the proposals of an interim administration and to the six-power resolution, passed over their protests, the two governments began to display a grudging willingness to compromise. But India refused to abandon its basic premises that accession was val1d and that the 1ssue was a question of legal rights. In addition, the contentions that faklstan should play no role in a plebiscite and that Indlan troops should be authorlzed to garrison the entlre state were advanced more firmly, and foolishly, for Faklstan could never accept them.

Zafrullah Khan continued to refuse recognition of the validity of accession and so was unable to give unreserved support to any measure that accepted the legality of the Indlan position in Kashmir. But in proposing an amendment to the six-power resolution, he indicated that Pakistan's conception of an interim government was no less weighted in favor of Pak1stan than was the Indian in favor of Indla. The sole deviation in Counc1l alignment came in Tslang's reinforcement of the Indian forces. Yet even this development made no appreciable change in the over-all Counc11 att1tude of neutrality. The voting pattern, aside from Islang's absterition on the Syrian resolution, remained the same. After six months of debate and negotiation, slight departures from a generally impartial approach appeared to 
place Argentina and Syria in support of Pakistan, China as Indla's advocate, and the United KIngdom and the United States in the forefront of a resolutely neutral bloc, a bloc that set the Counc1l line in all resolutions.

Indla and Paklstan emerged fron this latest serles of meetings with equal portions of success and setback. India, the loser in two previous bouts, had Indicated sufficient willingness to compromise to escape the criticism that had fallen on its prevlous totally intransigant attitude. The six-power resolution, whlle not granting all it asked, nevertheless gave to New Delhl the larger role in pleblscite arrangements. And although opposed to the Syrian resolution. India could yet claim satisfaction from it for it definitely gave Kashmir precedence over all other issues with the 11 kelihood that it would be the sole question serlously considered by the Council. Pakistan's legal position as a party in the dispute was more clearly established than had previously been the case. The six-power resolution recognized this and contained provisions which might lead to the legal employment of Pak1stani troops in Kashmir. And the Syrian resolution, although of slight practical value, demonstrated that the Council had not, officially at least, dismissed from consideration the Pakistan1 charges against India. 


\section{CHAPTER V}

\section{A MATTER OF SUBSTANCE}

\section{I}

With the establishment of the commission, the Security Council temporarily relinquished direct consideration of Kashmir. Areas of serlous disagreement remained, and nelther the Indian nor the Pakistani government had accepted unconditionally the six-power resolution defining the commission's competence. Yet prospects were far from inauspiclous, for six months of wrangling and compromise in the ineeting rooms at Lake Success had resulted in broad princlples--a ceasefire and plebiscite under United Nations ausplces-upon which a settlement might be constructed. And both New Delhi and Karachi had expressed willingness to confer with the comission.

For elghteen months, from June $16,1948^{1}$ to December 17. 1949, the five-member "creature of the Council" sought an answer to the question of Kashmir's future. Its search

IThe comission's first eleven meetings, to July 3 , took place at Geneva and were devoted to organization. Membership changed several times during the commission's life. The original roster consisted of Santos Gomez, Colombian diplomat; Jerome Klahr Huddle, United States ambassador to Burma; Egbert Graeffe, Belg1an diplomat; Dr. Josef Korbel, Czechoslovak ambassador to Yugoslavia; and Dr. Ricardo Sirf. Argentine minister to Denmark. The New York Iimes, June 17, 1943. 
was blessed with partial success for in Kashmir a cease-fire was arranged and a cease-fire line agreed upon. But certain questions, at first mere detalls, had become so magnified as to present almost insurmountable obstacles to a final truce and plebisclte agreement. The military situation in Kashmir had changed drastically, for Pakistan, contrary to its professlons before the Counc1l, had employed regular army units in the state after May 8, 1948 and had assumed direct military control of the tribesmen and of the Azad Kashmir forces. ${ }^{2}$ As a result, demilltarization of Kashmir through withdrawal of armed forces, at first thought a technical question to be settled by military experts, had become "a matter of substance." The new impasse brought from the commission majority a recommerdation that further mediatory activities be conducted by angle representative of the Council.

Council discussions following receipt of the final comission report resulted in a set of demilitarization proposals, based upon the commission's findings and recommendations drafted by General M.cNaughton. Although both India and Pak1stan found the suggestions unacceptable without extensive amendment, the councll viewed them as "falr and just" and on March 14, 1950 adopted a four-power resolution emoodying the essence of the McNaughton proposals. An Australian jurist,

2Ib1d., July 18, 1948. The New Delhi report contained a further Indication of change in the situation in Kashmir: "An Indian news agency reported today that the tribesmen in - Kashmir, once lnambering 80,000, have now dwindled to an insigniflcant force, leaving mest of the flghting to local insurgonts and to Pakistanis..." 
Sif Owen D1xon, 3 was named, on April 12, 1950, to the newly created post of United Nations Representative for India and Pakistan.

The Security Council experienced a change in membershlp twlce during the comission's existence. On January 1, 1949, Cuba, Norway, and. Egypt replaced Colombia, Belgium, and Syria. One year liter, Ecuacior. Indla, and Yugoslavia were elected to positions vacated by Argentina, Canada, and the Ukrainian Soviet Sociallst Feputilic. Thus, when the final commission report was debated, from February through Apr11, 1950, represented on the Council were Cuba, Ecuador, Egypt, Ind1a, Norway, and Yugoslavia in addition to the five permanent members. However, the Soviet delegate, boycotting Council meetings as a result of the dispute over Chinese representation, ild not participate in the discussions.

The first commission report covered activities during the three months from June 16 through September 22, 1943. The orlginal premier problems of an interim government for Kashmir and arrangement of troop-withdrawal details had faded before the imnediate necassity of a cease-rire with the discovery, on July 7, that three brigades of regular Pakistani troops had been operating in Kashmir since May 8. Pakistan's reasons for this action were necessity to forestall an Indian

${ }^{3}$ Sir Owen D1xon, 1886- educated in Austral1a, was appointed acting judige on the Victoria state supreme court in 1926. Since 1929 he has served as a justice of the Australian high court, apart from the years 1940-44 when he sat on varlous government war boards, $1840-42$, and was Australian amDassacior to the Uniteo States, 1942-44. 
offensive supposedly designed to crush Moslem opposition in the state, protection of Pakistani territory from possible aggression by Indian forces, and prevention of an influx of refugeesinto Pakistan:

Pakistan had not informed the Security Council of the presence of its troops in Kashmir because, by the time they had been sent into the State, the question had been entrusted to the Commission whose early departure for the subcontinent was expected. . In view of the Foreign Minister, the presence of Pakistani troops in Kashmir did not raise the question of international obligations since Pakistan had never accepted any with regard to non-interference in Kashmir. 4

Further legal justification was sought in the invalidity of Kashmir's accession to India, according to the Fakistani Interpretation of that union.

To meet a dangerous situation, the commission asked the governments to accept a resolution, drafted on August 13, whlch consisted of three parts: (1) a cease-fire proposal; (2) a truce agreement; and (3) a vague reaffirmation of the cieslre of both parties to settle the dispute by means of a plebiscite. The first part called upon the Indlan and Pak1stani military commands, at the earliest practicable date, to issue a cease-flre order applicable to all forces under their control. Milltary commanders were then to agree upon a permanent cease-fire line. Further:

The High Commands of the Indian and Pakistani forces agree to refrain from taking any measures that might augment the military potential of the forces under their control in the state of Jammu

4Ge offlcial Eecords, 3rd Year, Supp. for Nov., 1948, 
and Kashmir. (For the purpose of these proposals ferces under their control shall be considered to include all forces, organized and unorgandzed, flighting or participating in hostilities on their respective sides./5

The truce section of the resolution recognized the presence of Pakistani troops in Kashmir as a material change in the situation. 6 Consequently, Pakistan was to withdraw its forces and to secure the withdrawal of the tribesmen. Pending a final settlemcis, evacuated territory would be administered by local authorities supervised by the commission:

When the Commission shall have notifled the Government of India that the tribesmen and Pakistani nationals. . have withdrawn, thereby terminating the situation which was represented by the Government of India to the Security Council as having occasioned the presence of Indian forces in the State of Jammu and Kashmir, and further, that the Pakistani forces are being withdrawn. - the Government of Indla agrees to begin to withdraw the bulk of 1 ts forces. 1.7 Following withdrawal, and unt1l the dispute had been settled, India would maintain, in agreement with the commission, the minimum force necessary to ensure 1 aw and order in Kashmir. The Indian government accepted the proposals on the understanding that a cease-fire would accord no legality to

\section{Ibid., p. 32.}

6The first resolution concerning Kashmir adopted by the security Council $(s / 651)$ requested India and Pakistan "to inform the Council immediately of any material change in the situation which occurs or appears to either of them to be about to occur while the matter is under consideration by the Counc1l, and consult with the Counc1l thereon."

7 SC Officlal Records, 3rd Year, Supp. for Nov., 1948, s/1100, p. 33 . 
the presence of Pakistani troops, that Kashmir's sovereignty would not be affected, that Indian troops would occupy strategic evacuated points, that India would retain sufficient forces in Kashmir to guarántee security, and that Pakistan would not participate in the organization of the plebiscite. Pakistan weakened its acceptance with the conditions that India accede to plebiscite arrangements placing the two governments on an equal footing, that all Kashmir be placed under the survelllance of the commission, that evacuated territories be administered by local authorities in de facte control at the time of the cease-fire, and that Azad Kashmir be a party to any settlement. Pakistan could not speak for Azad Kashmir nor would it employ coercion:

Political control over the Azad Kashmir forces vests in the Azad Kashmir Government, and it is the latter Government alone that has authority to issue a cease-fire order to those forces, and to conclude terms and conditions of a truce which would be binding upon those forces. 8

In addition, Karachi rejected the portion of the resolution labeling the entry of Pakistani troops into Kashmir a material change in the situation.

The commission assented to the Indian qualiftcations but found that Pakistan's "clarifications" amounted to serlous reservations. Discussion of plebiscite arrangements was not yet pertinent and the commission had been informed previously by Karachi that Azad forces were controlled by the Paklstani high command:

\section{sioji.. pp. $41-42$.}


The commission observes with regret that. . Pakistan has been unable to accept. . . Without attaching certain conditions beyond the compass of this resolution, thereby making impossible an immediate cease-flre and the beginning of fruitful negotiations between the two Governments and the Commission to bring about a peaceful and final settlement of the situation in the state of Jammu and Kashmir.9

In analyzing the situation, the commission found two new factors primarlly responsible for fallure to achieve a cease-fire; (1) the existence of the Azad Kashmir movement as an organized political and military entity, assisted by Pak1stan and In control of large areas of Kashmir, and (2) the presence of Pakistani troops in the state:

The Securfty Council never contemplated during its debates that the Commission. . should deal with a situation involving military action between two regular armies.10

The positions of the governments on the question of the Pakistani forces had become unyielding. India insisted that they be withdrawn before the initiation of negotiations for a final settlement. Yet Fakistan refused to consider withdrawal unless Indian troops left the state simultaneously. Pakistan, "in 1ts desire to anticipate certain specific conditions which might provide the bases for a plebiscite, "ll had destroyed all possibllity of affecting an immediate cease-fire. Following recelpt of the first report, the Counc1l

\section{Ibld. , p. 49. \\ 10 Ibid., p. 52.}

1lsc offleisd Eecords, 3rd Year, 382nd Meeting, p. 5. 
requested that yet another attempt be made to achieve agreement on a cease-fire. The commission began negotiations with the Indian and Pakistani representatives to the United Nations and was able to report on January 10, 1949 that, as a result of acceptance by both governments of plebiscite provisions supplementary to the cormission's cease-fire resolution, neither Karachi nor New Delhi saw any reason for the continuation of hostilities:

Both Governments announced their agreement to orcier a cease-fire effective one minute before midnight, I January 1949, publicly expressing the hope that this decision may bring to the peoples of Pakistan and India a sense of closer friendship. 12

The now provisions called for a plebisclte immediately upon implementation of the cease-fire and truce measures of the original resolution. The secretary-general of the United Nations was to nominate a plebiscite auministrator who would be apfolnted officially by the government of Kashmir and derive all necessary powers from the state:

After implementation of parts $I$ and II of the Comm1ssion's resolution of 13 August 1948. . the Commission and the Flebiscite Administrator will determine, in consultation with the Government of India, the final disposal of Indian and State armed forces, wuch d1sposal to be with due regard to the security of the State and the freedome of the plebiscite. 13

Disposal of armed forces in the evacuated territories would be determined by the comission and the administrator in consul5/1196, p. 23 .

125c official Becords, 4th Year, Supp. for Jan., 1949, 13Lec. c1t. 
tation with local authorities. The United Nations agents would also organize the referendum and attest to its impartiality. Details of the vote would be settled following signature of a truce agreement. The second report concluded with a request that the plebiscite administrator be appointed as soon as possible.

But the commission's third report, forwarded to the Counc11 on December 17, 1949, demonstrated all too clearly that agreement on principle does not ensure a common approach to detail. Upon the commission's return to the sub-continent, the most urgent problems had been Implementation of the ceasefire and arrangement of truce provisions. Hostilities in Kashmir had ceased, and Karachl reported considerable progress In withdrawing tribesmen and other irregular forces from Kashmir. It was expected that by the middle of February, 1949 "the obligation of the Pakistan Government in this respect would have been fulfilled."14

Comprehensive truce proposals were completed on April 23. and the governments were requested to accept them without reservations. The commission would demarcate a formal ceasefire line. Since the military situation in Kashmir's northern areas was confused, disposition of the region would not be determined immediately:

Should the Commission and/ or the pleblscite Administrator conclude upon advice from the Observers, or upon reports from the Government 
of Indla, that it is necessary for the defence

of the area, the Commission and/ or the Pleb-

iscite Administrator may request the. Covernment ${ }_{15}$

of India to post garrisons at specified points. 15

Pakistan was to have seven weeks in which to withdraw its troops in successive contingents. India also was to withdraw the bulk of its forces:

The withdrawal will begin as soon as the Commission shall have notifled the Government of

India that the tribesmen and Pakistan nationals

- . have withdrawn, and that the Pakistan

troops are being withdrawn. . 16

Territory evacuated by Pakistan would be administered by local authorities under commission surveillance. Upon acceptance of the proposals, the commission would consult with India on the disposal of Indian and state forces and with "local authorities regarding the disposal of the armed forces in the territory to be evacuated by Pakistan troops. . " 17 The truce terms were not to be considered prejudicial to the territorial integrity or soverelgnty of Kashmir.

Nelther India nor Pakistan was able to accept the proposals without reservations. Pakistan, under no condition, would agree to Indian occupation of evacuated areas north of the cease-fire line and insisted on interpreting the "declared objective" of the truce terms to be a synchronization of the withdrawal of Indian and Pakistani forces so as to create a "mllltary balance" between the opposing forces. In order to

$$
\begin{aligned}
& 15 \text { Ibid. p. } 111 . \\
& 16 \text { Ibid. p. } 112 . \\
& 17 \text { Ibid. p. } 113 .
\end{aligned}
$$


maintain order in the evacuated areas, it would be necessary to reorganlze the Azai forces, which were to be considered "local authorities" and not subject to withdrawal or disbandment. Further, the guarantee of Kashmir's integrity and sovereignty introciuced a controversial matter and so should be omitted from the truce terms.

Indla found the proposals, further qualified by the Pakistani reservations, fundamentally opposed to the Indian position. The claim of Pakistan, much less that of Azad Kashmlr, to equality of rights in Kashmir in any sphere had never been acknowledged. India could never accept "synchronization" or "military balance" which would mean that Pakistani action would be contingent on Indian withdrawal and that Azad forces would remain in control of state territory. Pakistanl withdrawal and Azad disarmament would have to precede any move to diminish Indian strength:

The Government of India are prepared to discuss with the Commission the... formation of a Civil Armed Force for the maintenance of. . order in Azad. - territory, but both the composition and the character of isuch a force must be adjusted to this primary purpose and not to the creation of "a military balance between the forces on each side. 18 .

Lastly, since Indian forces were not speciflcally authorized to garrison the northern areas, Kashmir's security would be dangerously weakened.

Unable to agree upon polftical provisions of a truce, the governments nevertheless achieved a formal demarcation of 
the cease-fire line on July 27 . The agreement specified the positions of opposing forces and provided that "there shall be no increase of forces or strengthening of defences in areas where no major adjustments are involved in. . the cease-fire line." 19

Heartened, the commission suggested further conferences on a truce. In case no common ground could be found, the governments were asked to submit their differences to arbitration. Pakistan assented, but India, explaining that although it was not opposed to the principle of arbitration, It thought that the commission proposal was too vague, refused. W1thdrawal and Azad disarmament were not questions for arbitration but for immediate decision.

In analyzing developments during the year and half of its existence, the commission found that three principal issues impeding a solution had emerged in clear focus: disposition of Azad forces, (2) withdrawal of regular troops, and (3) the question of the northern areas:

The implementation of a truce which appeared to be question mainly of procedure and of short duration--approximately three months--became in fact a matter of substance. 20

Augmentation of Azad forces, officered by and working in close cooperation with the Pakistani military, had seriously complicated the basic problem of withdrawal. On that issue, the commission sided with India regarding a "milltary batance"

$$
\begin{aligned}
& { }^{19} \text { Ibid. . p. } 126 . \\
& 20 \text { Ibid., p. } 36 .
\end{aligned}
$$


and "synchronization" of withdrawal, which could not be interpreted without reference to the distinction diawn by the resolution between India and Pakistanl forces:

The Commission's reference to synchronization should be interpreted to mean that discussion with. . Indla concerning the withdrawal of the bulk of its forces would bnsue without delay and lead to the establishment of a time sequence for the two withdrawals. . after the acceptance of truce terms by both Governments. The Commission was not able to share the view of. Pakistan that the only method of assuring this form of synchronization was by the full and free exchange of information between the Indian and Pakistan Governments regarding withdrawal plans. 21

But the commission disagreed with India on the northern areas. A cease-fire throughout Kashmir was necessary during the plebiscite, and the entry of Indian troops into these reglons might be opposed bitterly and forcibly by the solidly Moslem population. While it was doubtful whether the north was effectively in Pakistani control during the autumn of 1948, by January 1, 1949 state authority had been eliminated from the area and Pakistan "undeniably held military control." 22

The commission doubted that five-member body was sufficlently flexible and suggested a single representative with broad authority as a more effective means of finding "the balance and compromise necessary to. - . settlement of the dispute." 23 The representative's powers should include

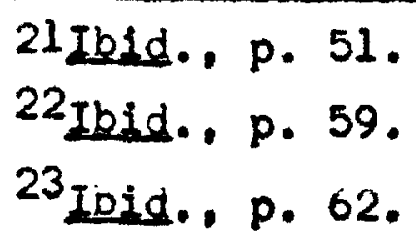


"authority to settle eventually, by arbitration, such issues involved in the demilitarization. . which impede the plebiscite." 24 The as yet unnamed representative was advised to commence his work with a modification of the original demilitarization plan:

Such a modification must treat the problem of demilitarization as a whole, eliminating all distinctions and comprising all questions con$\because$ cerning the final disposal of all armed forces In the State of Jammu and Keshmir. 25

And the commission's successor would be aided in his task, for on March 22 Admiral Chester W. Nimitz 26 of the United States had been appointed plebiscite administrator, fulfilling the request in the commission's second report. Once demilitarlzation and a truce had been achieved, Nimitz could undertake arrangements for the referendum.

A minority report was submitted on December 16, 1949 , by Oldrich Chyle, Czechoslovak commission member. He stated bluntly that the commission had failed, failed because the resolutions of August 13, 1948 and January 5, 1949 were not based on the actual political situation. No compromise on the basis of the resolutions was acceptable to both parties.

$$
\begin{aligned}
& 24 \text { Ib1d.. p. } 63 . \\
& 25 \text { Ibid. . p. } 52 .
\end{aligned}
$$

${ }^{26}$ Fleet Admiral Chester William Nimitz, 1885-, a 1905 graduate of Annapolis, has served the United States in two world wars. Commander of the Atlantic submarine force In the first war, he was commander in chief of the Facific fleet from 1941 to 1945. Admiral Nimitz was awarded the newly created rank of fleet admiral of the navy in 1944. From 1945 he was chief of naval operations. 
The majority had shown "insufficient sagacity" by underrating the significance of the Azad forces and by failing to take Into account the situation in the north when drafting its truce proposals. The Untted States and the United Kingdom were largely responsible for the failure by pressing for arbitration, a step the comnission had not been authorized to take. The American and British governments had continually interfered with the work of the commission:

If peaceful solution of the dispute is to be attained it has to be assured that the Commission does not become an instrument of policy of certain Great Powers. 27

Not lack of flexibility but too much flexibility had undermined the commission's "vain attempt" to please both parties. Chyle recommended a new commission, consisting of representatives of all Council members, with complete freedom from interference guaranteed.

Following the consideration of the third report, the Council authorized General McNaughton, Council president durIng January, 1949, to Inftiate further negotiations. McNaughton forwarded his report on February 3, 1950. Pakistan would accept the demilitarization proposals subject to slight changes in wording. India proposed several amendments, the most Important beling the withdrawal of all regular and irregular forces from Kashmir, the disarmament of Azad forces, and Indian military control of the northern areas with civil administration by the state government.

\section{${ }^{27}$ SC Official Becerds, 4th Year, Special Supp. No. 7,} S/1430, p. 203 . 
McNaughton prefaced his formal proposals with a suggestion that future action be based upon existing points of agreement and that fudgment on past issues be avoided. He reaffirmed the necessity of a plebiscite and called for a program of progressive demilitaxization designed:

- - to reduce the armed personnel in the State - - on each side of the cease-fire line to the minimum compatible with the maintenance of security and of. - . order, and to a level sufficlently low and with the forces so disposed that they w11I not constitute a restriction on the free expression of opinion. . .28

Th1s meant withdrawal of regular Pakistani and Indlan forces not essential to state securlty as well as disbandment of local forces, the state army and Azad Kashmir. The demilitarized northern area would be administered by local authorities under United Nations supervision.

Agreement between the governments should be reached upon number of points:

(a) The Government of Pak1stan should give unconditional assurance to the Government of Indla that it will deal effectively within its own borders with any possibility of tribal incursion into Jammu and Kashmir.

(b) The Governments of India and Pakistan should confirm the continued and unconditional Inviolability of the cease-fire line.

(c) Agreement should be reached on the basic principles of demilitarization. .

(d) Agreement should be reached on the minimum forces required for the maintenance of security and of. . order, and on their general disposition.

(e) Agreement should be reached on a date by which the reduction of forces. . Is to be accomplished.

(f) Agreement should be reached on the pro-

$2 \varepsilon_{\text {SC }}$ Offletal Becords, 5th Year, Supp. for Feb., $1950, s / 1453$, p. 14 . 
gressive steps to be taken in reducing and redistributing the forces to the level envisaged - above.29

A United Nations representative would supervise the progressive stages of demilitarization and would have authority to "interpret" agreements on these points. When demilltarization had not been accomplished, the plebisclte administrator would take up his duties.

Although unconditional acceptance of the McNaughton proposals was not offered by elther Indla or Pakistan, the Counc1l nevertheless acted upon them in the four-power (Cuba, Norway, the United KIngdom, and the United States) resolution adopted on March 14, 1950. The draft asked for the "resolution of the outstanding difficulties" based upon the "substantlal measure of agreement on fundamental princlples already reached." Demilitarization steps should be taken immediately:

The security council.

1. Calis upen the Governments of India and Pakistan to make Immediate arrangements without prefudice to their rights or claims. . to prepare and execute within a period of five months - a programme of demliltarization on the bas1s of the principles. . Of General McNaughton's proposals or of such modifications of those principles as may be mutually agreed. . .30

A United Nations representative would "assist in the preparation and. - supervise the implementation" of demilitarization and would "Interpret" agreements reached between

29 Ibid. p. 15.

30yearbeok of the United Nations, 1950 (New York: Columbia University Fress, 1951), pp. 303-09. 
India and Pakistan. He would exercise all power formerly devolving upon the commission, which was officlally dissolved. At the "approprlate stage" he was to arrange for assumpiion by the plebiscite administrator of functions assigned to the latter through agreements between the parties. The resolution was approved with eight votes in favor (China, Cuba, Ecuador, Egypt, France, Norway, the Unlted KIngdom, and the United States); none opposed; two abstentions (India and Yugoslavia); and one member, the Soviet Union, absent.

\section{II}

Six primary 1ssues--Pakistani troops in Kashmir, the Azad Kashmir forces, troop withdrawal, disposition of Kashmir's northern districts, Interpretation of plebiscite conditions, and the McNaughton proposals reoccurred in Council debates during the eighteen months of commission activity. India's S1r Benegal Narsing Rau 31 belabored the facts of law and the perfidy of Pakistan with passion on the first issue to arise, Pakistani military operations in Kashmir. Rau had a telling point and he let neither the Counc1l nor Paklstan forget it. Within a fortnight after Pakistan had righteously sworn to the Council that it was not an active party in the Kashmirl disturbances, Pak1stani troops had moved into the

${ }^{31}$ Sir Benegal Narsing Rau, 1887- , educated in Indla and in England, folned the Indian Civil Service in 1910. He served on several provincial high courts and from 1944 to 1945 he was prime minister of Jammu and Kashmir. In 1946 Rau was constitutional adviser to the constituent assemblies of both Indla and Burma. Since 1949 he has been permanent Indian representative to the United Nations. 
state, development that could be viewed only as a material change in the situation. Yet Pakistan had not seen fit to inform an agency of the United Nations luritil several months later:

Thus, India's original complaint alleging ald by Pakistan. . . was now proved to be true or at least, to have become true in an aggravated form; not only was there aid, but the Pakistan Army was actually inside the state giving ald and direction land, indecd, engaging in actual flghting. 32

Self-defense was no jystification, for under Article $51^{33}$ of the Charter there were two limitations on that right-there must be an armed attack upon a United Nations member, and measures taken in self-defense must be reported Immediately to the Security Council. Rau belittled the Indian actions complained of as merely tactical maneuvers designed to relieve military pressure in Ladakh and Poonch.

Zafrullah Khan, trapped by an obvious violation of obligations accepted in several Councll resolutions, flayed wildiy at the Indian charges in spasmodic tirddes of questionable legal right and unrestrained emotion. Ignoring the

32SC Qfficial Records, 5th Year, 463rd Meeting, p. c.

33Art1cle 51: "Nothing in the present Charter shall impair the inherent right of individual or collective selfdefense if an armed attack occurs against a Member of the United lations, until the Security Council has taken the measures necessary to maintain international peace and secur1ty. Measures taken by Members in the exercise of this right of self defense shall be Immediately reported to the Security Counc1l and shall not in any way affect the authority and responsibility of the security Council under the present Charter to take at any time such action as it deems necessary in order to maintain or restore international peace and security." 
technical and legal aspects of the situation, he reiterated the defense that an all-out offensive by Indla had necessitated an all-out reaction by Pakistan. The most pressing reason for Pakistani action had been the need to forestall capture of certain vital irrigation headworks on the Jhelum, the Chenab, and the Incius which irrigated nineteen million acres in West Pakistan. If Kashmir were to accede to India, the headworks would be lost and the supply of water cut off altogether. 34

Turning from economics to strategy, Zafrullah Khan departed from the immediate situation to plead that, no matter what the legal points were, Kashmir was essential to Pak1stani security and must be prevented from falling into the hands of Ind1a. India, in possession of the state, would outflank Pakistan's entire northwest defense system:

If Kashmir should accede to India, Pakistan might as well, from both the economic and the strategle points of view, become a feudatory of India or cease to exist as an independent soverelgn State. That is the state of the two sides; these are the considerations. 35

Rau, eager to keep his opponent in full retreat,

${ }^{34}$ Although a situation much like this occurred in the case of headworks falling to India as a result of partition (see page 5, note 4), Oppenheim frowns on the practice: "A State, In spite of its territorial supremacy. is not allowed to alter the natural conditions of its own territory to the disadvantage of the natural conditions of. . . a neighbouring State-for instance, to stop or divert the flow of a river which runs from 1 ts own into nelghbouring territory." Oppenheim. p. 259.

p. 8 .

35 sc effictal Becerds, 5th Year, 464th Meeting, 
selzed on this remark as indicating that Pakistan was no longer content with a democratically decided accession but desired outzight possession of Kashmir:

At this point of the argument he seems to have forgott $\in$ n that the matter is to be decided not by the comparative needs of lakistan and of India, but by the wishes of the people of Kashmir. . If I may say so without any offence, the wolf may need the lamb desperately, but the lamb may heve different wishes in the matter. 36

Rau found the Pakistani record on the issue of the augmentation of Azad forces equally damaging, for agaln, obligations had been violated. He relled upon the testlmony of the commission on this point; both the third report and Its accompanying minorlty report had found the increased strength of Azad Kashmir a materlal change in the situation, a development "contrary to the understanding that Pakistan would not use the period for consolidating its position or increasing its military potential."37 India's real polnt on the 1ssue was not whether disarmament of the Azad forces should occur during a certain period but that it should take place before the bulk of the Indlan army was withdrawn from Kashmir.

Zafrullah Khan relied upon a novel interpretation of the commission truce proposals, an interpretation at odds with the commission's own version as contained in the third report, to argue that is sarmament and disbandment of Azad

36 sc official Becerds, 5th Year, 466th Meeting, p. 9. 37 SC Official Becorisi, 5th Year, 463rd Meeting, p. 7. 
troops had never been intended to take place during the truce perlod. The commission was aware of Azad strength when it formulated the truce terms, yet the provisions did not mention Azad Kashmir--"conclusive evIdence" that Azad forces were not Intended to be Included. 38

On the third question, the Indian position had not changed since dispute flrst arose as to the correct interpretation of the truce proposal withdrawal provisions. India would not consider moving the bulk of 1 ts troops from Kashmir unt1l plans for the disbandment of Azad forces as well as the withdrawal of regular Pakistanl forces were underway. If any Azad contingents were to assist in maintaining order, they must be small and matched by non-Azad groups. Only when the tribesmen and Azad and Paklstanl troops could no longer maintain large-scale milltary operations in Kashmir would Indla consent to gradual removal of 1 ts forces and partial demobilization of state troops.

Zafrullah Khan would not desert his highly Individualistic interpretation of the truce terms. Azad troops were legitimate local forces, were not covered by the proposals, and withdrawal should not be contingent upon their disbandment. In real1ty, he charged, the principal obstacle to a truce was Indla's refusal to communicate withdrawal plans to Pakistan in order to effect a synchronized retirement. The opinions of Indla and of the commission to the contrary. 
Zafrullah Khan refused to abandon the principal of "synchronization."

Soverelgnty was the theme of the Indian case on the fourth 1ssue, control of the northern districts during the pre-plebiscite perlod. Accession to India, sald Rau, had not meant dissolution of the government of Kashmir; it retained internal powers. If a pleblscite were to be held for all of Kashmir, the authority of the state government must not be disrupted beforehand. The Counc1l, In providing that the plebiscite administrator should recelve his powers from the state, had recognized this, but he could not do so if the northern areas were detached from the state. Rau refused to compromise further on this issue:

India cannot possibly go on making these concessions and frittering away 1 ts position. It is urged that. - Indis should acquiesce in them because, it is sald, they are. . temporary and only a step towards. . . the plebiscite. But it is Incomprehensible to us why pressure should always be brought to bear on Indla to acquiesce in wrong, and why, for a change, some pressure should not be brought to bear on the other s1de to acquiesce in the right on the same grounds. 39

Zafrullah Khan probed the flaw in Rau's argument. If Indian reasoning on "authority derived from the state" were pressed to its logical conclusion, it would necessitate restoration of state authority and Indian military control throughout the region bccupied by Azad or Pakistani forces: 40

All that was contemplated was that the Plebiscite

${ }^{39}$ sc efficiel Records, 5th Year, 463rd Meeting, p. 13. 40India expounded exactly this proposal before the Counc1l on Abr11 19. 1948 (see page BS). 
Administrator should be deemed to have derived his powers, as a matter of legal technicallty, from the State of Jammu and Kashmir. Not even the Government was mentioned; it was the State of Jammu and Kashmir, as a legal doctrine.41

The fifth clash arose on the issue of the plebiscite itself. In thrust which appeared designed to topple everything the counc1l and the commission had constructed since January, 1948, Rau questioned the soundness of repeated references to Indo-Pakistanl "agreement" on a plebiscite. The meaning of "plebiscite" was still very much in disagreement:

Indla offered a plebiscite upon certain. . conditions which amount briefly to this, that the state must be restored to its normal conditions before the plebiscite is held. India stands by that offer. supject to those conditions. Pakistan, on the other hand, appears to desire a plebiscite with the state in its present disrupted and abnormal condition. ${ }^{2}$ Where there has been no meeting of minds, $1 t$ is not possible to spell out in agreament. 42

A plebiscite for the entire state and unquestloned soverelgnty of the state over its entire territory were inseparably connected, Rau maintained.

Zafrullah Khan held fast to plebiscite as the ultimate determinator of Kashmir's disposition. And he pointedly charged that the prime obstacle to arrangement of a referendum was not a matter of acceptable conditions but of India's insistence that it alone should determine those conditions:

${ }^{41}$ sc official Recerds, 5th Year, 465th Meeting, pp. ${ }^{42}$ SC officlal Becords, 5th Year, 463rd Heeting, p. 23. 
India's insistence is that, although that settlement should be with the United Nations and the United Nations should take the responsibility for it, that settlement must be what India says. 43

The MCNaughton proposals provoked the final controversy. India was in agreement on certain provisions but could not approve the ientire plan. India had accepted the commission's truce proposals on assurances that Kashmir's soverelgnty would not be questioned, that Azad Kashmir's legitimacy would not be recognized, that Azad forces would be disarmed, and that the northern areas would be consldered in implementation of the terms. The net effect of McNaughton's plan was to neutrallze every assurance relied upon by Indla. To avold consideration of past issues would be to Ignore the dispute's origin and development. Security in the north rested entirely upon Pakistani good will:

May I ask what arrangements Pakistan made to prevent the tribal incursions of Octoper 1947 ?

What is to happen if the situation recurs?

India can take no risks in this matter. 44

But most serious of 11 , although India's original complaint had been suistantiated, although the Pakistani army should have been withdrawn from Kashmir long ago, the proposals contemplated no effective action on this matter:

Indesd, the very reverse is the case. By sanctioning the administration of the northern areas by the existing local authorities, these proposals, in effect, recognize and help to perpetuate the unlawful occupation of these areas by

${ }^{43}$ Sc Offlclal Records, 5th Year, 466th Meeting, p. 27. 445e officlal Becerds, 5th Year, 463rd Meeting, p. 16. 
Pakistan. 45

Although not quite convinced that they guaranteed a thoroughly Impartial plebisclte, Zafrullah Khan was willing to accept McNaughton's suggestions. Pakistan would reconc1le 1tself to the risk, trusting in the integrity of the plebiscite administrator to see that the feferendum was "as free and impartial as human effort can make it."46 Zafrullah Khan grew somewhat sarcastically critical of Rau's attltude toward the proposals:

His only prejudice is that his pdint of view. which was unacceptable to the Cornmission, has by and large been equally unacceptable to General McNaughton. 47

The Council members, greatly exercised over the Pakistani Incursion Into Kashmir following receipt of the first commission report, largely ignored this issue in succeeding discussions and drew together in a practically unanimous neutral attitude on "the matters of bubstance" and in urging acceptance of the MeNaughton proposals. Pakistan's entry Into Kashmir could only be vlewed, said Isiang, as a materlal change in the situation, and Fakistan was at fault in not having reported immediately to the Council. But when discussion reached the commission reports, Isiang assumed an attltude critical of both parties, for he thought the three princlpal differences were causing difficulties out of all

45 Iibid. . p. 10.

46 Sc efficlal Becords, 5th Year, 469th Meeting, p. 12.

47 SC Qfficlal Resends, 5th Year, 465th lieeting, p. 12. 
proportion to their importance:

The importance of this disagreement has been magnified, because each side puts upon the manner of troop withdrawals a political interpretation, as if the settlement of the question of accession of. . Kashmir to India or Pakistan depended upon the method and timing of the withdrawal of their respective forces. 48

Pakistan's action was also criticj.zed by Arne Sunde 49 of Norway, who nevertheless favored acceptance of the situation and a fresh start toward a solution:

I frankly doubt the utility of threshing out again in the Security Council the manifold and complex issues which are at stake in this case. Tentative suggestions swiftly become unalterable opinions when they are expressed in this Council. and arguments advanced in the heat of discussion have a tendency to become vested with the habilements of national prestige. 50

It would be traglc should differences on such essentially procedural problems as withdrawal and demilitarization block a final settlement. He had followed the arguments carefully, avolding premature persuasion, but "there is no longer any doubt in my mind as to whose reasoning has the $b$ st foundation of fairness and justice. . General McNaughton's." 51

48 SC Official Records, 5th Year, 467th Meeting, p. 31.

${ }^{49}$ Arne Sunde, $1883-$, has represented Norway in numerous posts abroad and in several international arbitration cases. He was a member of lthe government in exile in London during the war years. Sunde has been Norway's permanent representative to the United Nations since 1948.

p. 5 .

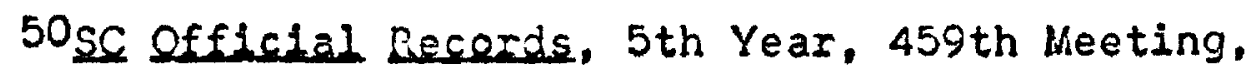
$5 l_{\text {SC }}$ efficial Recerds, 5 th Year, 467th Meeting, p. 2. 
A new volce, that of S1r Alexander Cadogan, 52 spoke for Britain during this perlod, but Whitehall's accent was unchanged. Slipping off the fence momentarily to join his confreres In criticlzing Paklstan's action in entering Kashmir, Cadoganssoon regalned his perch, resigning himself to the situation as it existed. In favoring the McNaughton proposals, he echoed Noel-Baker's position on the six-power resolution; 53 the proposals were not a final solution but rather another step toward a plebiscite. The Counc1l should avold dredging up past issues in seeking a solution, for what had to be discussed was a question of mechanics:

How, then, can elther side feel justified in pursuing points. . which can do no good and which, unintentionally I know, merely serve to frustrate the early expression of the will of the people? . Can it be anyone's wish to allow legal points of doubtful relevance to stand in the way of progress? 54

Ernest Gross 55 of the United States resolutely

\section{Alexander Cadogan, 1884- , has served the} Brit1sh foreign office in Constantinople, Vlenna, Peking, and at home. Permanent under-secretary of state for the forelgn office from 1938 to 1946. Cadogan attended the RooseveltChurchill Atiantic meeting, was chalrman of the Dumbarton Oaks conference in 1944, and attended the United Nations Conference on International Organization in 1945. He 1s a former United KIngdom permanent representative to the United Nations, 1947-49.

53 see page 90.

54 Sc official Becords, 5th Year, 467th Meeting p. 7.

${ }^{55}$ Ernest A. Gross, 1906- , has been in United States government service since 1931, with the state department. 1931-33. He has served as legal advisor to a number of federal agencles and to Amerlcan delegations to international conferences. Gross was deputy assistant under-secretary of state for occupled areas, $1946-47$, and has been a deputy representative to the United Nations ince 1949. 
champloned the McNaughton proposals and attention upon the problems of the present and future rather than the past:

Demilltarization does not prefudge the rights or claims of the parties. It need not, therefore, rest upon those rights or claims. It is however, an essential prerequisite for a solution of the dispute. 56

Demilitarization in a single perlod was consistent with what should be the controlling consideration-minimizing the posslbility of a resumption of host1lities. Thus the process should be timed so that at the conclusion of the dem1lltarization period there would remain no force with an aggressive potentlal. Gross thought it unfortunate that Indla had rejected the McNaughton plan, which had been designed to remove the threat of renewed host1lities.

\section{III}

The commission phase of the Kashmir dispute was not altogether devold of success. Hostilities in Kashmir had ceased; a plebiscite administrator had been appointed; the commission's August 13, 1948 truce proposals provided a basis for further demilitarization formulas; and, with the appointment of the United Nations representative, the Council had adopted a new approach to the problem. But other aspects of the situation in Apr11, 1950 were less encouraging. Of the 1ssues prominent when the commission began operation, the question of an interim administration had for the moment ceased to be of vital importance, and the general problem of

56 sc Official Recerds, 5th Year, 467th Meeting, p. 15. 
demilitarization had been fractured into technical disagreements on the disposition of the Azad forces, phasing of the withdrawal of regular Indian and Pakistani forces, and stewardship of Xashmir's northern districts during the prepleblscite period. Although these differences were primarily procedural in nature, the intranslgant attitudes of both governments had Inflated them out of all relation to their true importance. Withdrawal, hinging upon varying interpretations of "synchronization" and "balance of forces," Indicated the extent to which the broad principle of a plebiscite could become mired in technicalities.

The major development during the perlod was the open operation of regular Paklstanl forces in Kashmir, a clear contravention of Pakistan's original representations to the Counc1l and of obligations accepted in the initial resolutions. Concomitantly, the tribesmen, Instigators of the dispute, ceased to be a significant factor.

The genesis of future issues could be observed in Council and commission actions. Arbitration of differences, tentatively advanced by the commission, rejected by India and accepted with reservations by Pakistan, received the approval of the Council and was implied in both the McNaughton proposals and the four-power resolution. And it was dificult to belleve that demilitarization, which had been of flaming importance when proposed in two phases, would be less of an issue in one phase.

The positions of both governments on the issues of 
this perlod flowed from their basic approaches to the entire problem. The cardinal featurecof the Indlan stand was that Indla was in Kashmir by right and that Pakistan could not aspire to equal footing in the contest. From the fact of accession resulted India's responsibility for the security of Kashmir; hence, demilitarization must leave in the state sufficient Indian and state forces to safeguard that security. A pleblscite would be for the purpose of confirming accession, which was, in all respects, already complete. India's claims regarding the northern areas were also based on its fundamental argument. Refusal to discuss with Pakistan the detalls of Indlan withdrawal was not only in line with that portion of the truce proposals providing for the prior withdrawal of Pakistani troops, but followed upon Indla's insistence that Pakistan had no legal rights in Kashmix. The position on the Azad forces was, again, Ilnked with Kashmir's securlty.

The Pakistani approach was diametrically opposed to the Indian. Pakistan attempted to avold deserved condemnation resulting from operation of its troops in Kashmir through arguments on Indian aggression, illegality of the Indian presence in Kashmir, and economic and strategic considerations making possession of Kashmir a necessity for Pakistan. Pakistan considered itself as having equal status with India and entitled to equal rights. This claim influenced its position on implementation of the truce, which should establish a balance of forces between the partles. Thus Pakistan asked to be apprised of Indian plans before signing a truce 
agreement. Pakistan regaried the Azad forces as local and not covered by the truce terms. On the question of the northern areas. Paklstan denied India's clain to assume defense of the territories as a result of the established relations between India and Kashnir.

Fositions of Counc1l members were notewarthy for an almost uniform neutrallty. Indications of favoritism, which had emerged in June, 1948, had disappeared. Electlons to the Counc1l had removed Pakistan's adherents, Argentina and Syria, from the scene and their successors were consistently impartial. Islang, at one time sympathetic toward India, had returned to the neutral fold. The Council attitude toward the McNaughton proposals and the four-power resolution, deslgned to "balance the scales" between the partles, bore out th1s impression of impartiality. Abstentions from the ballot on the four-power draft were in no sense contradictory. India abstalned as a party to thp dispute, and Yugoslavia, not opposed to the alms and provisions of the resolution, did not belleve that it gave sufficient consideration to the basic problem, the welfare of the people of Kashmir. 57

Pakisten could find more cause for satisfaction with the results of commission activity than could India. The shadow which darkened the fakistani position following armed entry Into Kashmix had been dispelled in succeeding months, for the Council appeared willing to regard the development as

57 SC Official Becerds, 5th Year, 470th Meeting, p. 4. 
a falt accompli and to proceed from the actualities of the situation. This worked to the disadvantage of India, whose position had been but slightly modified since January, 1948.

As a result of New Delhi's unchanging approach and Council acceptance of the existing situation, the hicNaughton proposals and the four-power resolution appeared more favorable to Pakistan than to Incia. Although Pak1stan was not granted an uncue advantage, Karachi would accept any formula recognizing its position as a legal party to the dispute. But New Delhi would hot assent to any departure from its original position, which barred any solution at all acceptable to Paklstan. 
CHAPTER VI

THIRD PHASE

I

Since April, 1950, a single Unlted Nations representative has sought success where the Security Council and a five-member commission found defeat. Successive representatives, like the Council and commission before them, have discovered that technicalities, grown to matters of substance, continue to impede final settlement. And while agents have negotiated with the governments, reported to the counc1l, then returned to negotiations in an apparently unending cycle, Kashmir has quieted under the heavy hand of stalemate. Iwo armles, no longer engaged in active hostilities, sit out the monotonous months across a cease-fire line intended as a temporary demarcation between battle forces but which has assumed the character of a political boundary. Denunciation and recrimination no longer flash between New Delh1 and Karach1, and the eyes of the world public have turned to other, more recent conflicts and crises. Kashmir, once blazing 1ssue claiming full attention from world statesmen, has become a repetitious disagreement occasionally ruffling the surface of Indo-Pak1stanl relations, another bit of unfinished business regularly $-130-$ 
reappearing on the Security Counc1l agenda.

Political activity within Kashmir did not come to a halt with invasion. Amld persistent rumors that the is actually Imposing a police regime upon the state, Shelkh Abdullah has consolldated his position. A program of land reform and reduction of farmers' debts has given the Kashmirl peasant, for the first time in recent history, an economic position a jot or two above the wretched. 1 This, and other reforms, has resulted in considerable popularity for the Shelkh's administration, and there is reason to belleve that in a plebiscite, many Moslems under Shelkh Abdullah's jurisdiction would vote for his candidate, Indla, to show appreclation for the pollt1cal stability and relative economic prosperity that he has brought to Kashmlr. 2

But certain of Shelkh Abdullah's achievements have not been viewed so favorably by the international forum. A constituent assembly was called on October 27, 1950 to determine "the future shape and affillations of the State." 3 Despite repeated Indian assurances that the assembly is intended only to frame a state constitution and has no power to derlde the question of accession, 4 Pakistan and the Securlty Council have

\section{IThe New Yerk IImes, February 3, 1952.}

2Alice Thorner, "Indla-Pakistan Tensions Focus on Kashmir," Eoreign Rolicy Bulletin. XXLX (March 17, 1950), p. 3. pp. $126-27$.

${ }^{3}$ SC Official Records, 5th Year, Supp. for Dec., 1950,

4nThe question has been asked whether the Const1tuent Assembly of Kashmir can decide the question of accession. The 
remained suspicious of Sheikh Abdullah's intentions. That they have reason has been indicated In recent months. In Apr11, 1952, She1kh Abdullah clained full soverelgnty for Kashmir, stating that "no Parliament, be it that of India or any other country, has any authorization here" and that KashmIr, as an "autonomous republic within the Indian Union," would not accept full Integration with India as long as re11glous prefudice against Moslems existed in Ind1a. ${ }^{5} \mathrm{He}$ acted upon this principle in June, 1952 by asking the constituent assembly, commencing to act like a legislative assembly, to dethrone the maharaja and to establish an elective office of chief of state. 6

In response to such actions, and to Indications datIng from the Instlgation of the dispute that many Kashmiris preferred Independence to accession to elther Indla or Pak1stan, Ind1a, In July, 1952, granted to Kashm1r "a large measure of self-government within the "Indlan unlon."7 Yet India's view of the polltical relatlor,ship between Srinagar and New Delht remained the same: "Kashmir's accession to the Indian government is complete in law and fact-it is a part

answer is NO. The Assembly may express 1ts views on the subject but it has not power to decide the question. The Government of Incla has made this clear more than once." some questions and Answers on Kashmir. Government of India, p. 8 .

5The New York Iimes, April 12, 1952.

6Ibid. , June 11. 1952.

7Ibid. , July 25, 1952. 
of India." 8

Wh1le such events took place in Kashmir, the Security Counc1l and its ageht; the United Nations representative, continued the search for a solution. From Apr11, 1950 to June, 1952, the Counc1l recelved four reports from the representatives, accepted Sir Owen Jixon's resignation and appolnted his successor, adopted two resolutions concerning Kashmir, and consistently recommended continuation of the representative's activities.

The two-year period covered additional changes in Council membership. Throughout 1950, members were Cuba, Ecuador, Egypt, India, Norway, and Jugoslavia in addition to the five permanent members. In January, 1951, Braz11, the Netherlands, and Turkey replaced Cuba, Norway, and Egypt. One year later, Chile, Greece, and Pakistan succeeded Ecuador, Yugoslavia, and India. Thus, during 1952, the membership has been Braz1l, Chile, Greece, the Netherlands, Pakistan, Iurkey, and the states permanently represented.

Sir Owen Dixon, in submitting his first report to the Counc1l on September 15, 1950, requested that it be his last, that it be regarded as the flnal step in the discharge of his functions. He believed himself unable to contribute further toward a settlement. Dixon had arrived in the sub-continent ten weeks after the Councll had requested the governments to take immediate steps toward drafting a demilltarization

8Lec. sit. 
igreement:

The situation. - presented strange features.

The partles had agreed that the fate of the

State as a whole should be settled by a general

plebisclte, but over a considerable period of

tine they had failed to agree on. . Prellm-

inary measures. - necessary. . before it

was possible to set up an organization to take

a plebiscite. . The cease-fire line itself

was held in strength and thus two considerable armies stood opposedt to one another. 9

Indian-occupied territory was administered by She1kh Abdullah's government and was garrisoned by Indian troops and state forces. On Pakistan's slue, the Azad governinent held authority in the western areas, but political agents directly responsible to the Pakistani government controlled the horthern regions. Dixon flrst sought to negotiate on the measures necessary for commencement of the plebiscite administrator's dutles:

Only if and when I was satisfled that no such agreement could be brought about and that all real chance of it had ended, ought I to turn to some form of settlement gther than plebisclte of the whole State. 10

He began his task with assurances to Indla that, although unable to lndict Paklstan as an aggressor, he would accept the contention that the crossing of the Kashmiri border by hostile elements had been contrary to International law and that "when. - units of the regular Pakistani forces moved 1nto. . . the State, that too was inconsistent with

\section{${ }^{9}$ SC Offietal Eecords, 5th Year, Supp. for "Sept.,} 1950, s/1791, p. 26 .

10 Ib1d. . p. 27. 
International law." 11

With that understanding, Dixon proposed a demllitarlzation program, the first step of which would be withdrawal of Pakistanl forces, to be followed by troop reductions in Indian-held territory. India and Pakistan would concurrently undertake disarmament of state forces and of Azad troops: Operations would be divided Into phases, detailed plans for which would be prepared by the chlefs of staff, and the number of troops remalning in Kashmir would be as small as possible. Administration of evacuated areas would be by existing authorities, under United Nations survelllance, and according to custom or law prevaliling prior to lnvasion:

I proposed that it should be expressly provided that neither that provision nor any other provision. - should. . Import any recognition of. - iegal authority in such territory other than one depending upon and derlved from the law of the State or to imply any derogation from or prejudice to the soveIeignty of the state.12

Administration of the northern districts would be by United Nations officials whose powers would be dependent upon the custom or law of the areas as of August 1, 1947 and who might. exercise their authority through existing local channels.

The cease-fire line was to continue as a boundary but It would be preferable if a single government exercised power throughout the state during the plebisclte period. To achleve this, Dixon suggested three alternatives: (1) a simple

11 Ibid., p. 29.

12Ibid.. p. 33. 
coalition government; (2) Interim administration by individuals outside state polltics, half Hindu and half Moslem; or (3) administration conducted entirely by UnIted Nations agents.

Reactions were not favorable. New Delh1 rejected the withdrawal proposal on grounds of state security and objected to plans for the evacuated areas since many of the local mag1strates, appolnted following invasion, were unacceptable to India. To curb the authority or to alter the composition of the state government would Interfere with Kashmir's soverelgnty. Pakistan would not accept provisions which took control of northern districts out of Azad or Pakistanl hands. Dixon concluded that agreement on essentials of a plebiscite for the entire state was virtually impossible:

I became convinced that Indla's agreement would never be obtained to demilitarization in any such form, or to provisions governing the period of the plebiscite of any such character, as would. . permit of the plebiscite being conducted in conditions sufficlently guarding against intimidation and other forms of influence. . by which the. falrness of the plebiscite might be imperilled.13

He then asked the governments if they would agree to a pleblsclte restricted to certain disputed distrlcts, speclfically the Vale of Kashmir. Remaining areas would be awarded automatically to whichever dominion the inhabitans clearly favored, or as a result of local referendums. Pakistan vehemently protested such an arrangement, charglng that It constituded breach of India's original plebiscite

13Ioid.. p. 36. 
promise. India would consider the proposal on condition that areas in which there was no doubt as to the preference of the population would be awarded to India or Pakistan without pleb1scites, and that boundary demarcation would have due regard to geography and the requirements of an international border. 14 Although Pakistan refused to consider such a scheme, It would accept a simple partition without a plebiscite: - a solution having the advantages of being immediate in Its operation and self-executing; Pakistan vould consider the matter, provided that it took the Kashmis Valley. I had ilttle doubt however that Indla would not concede fhe Valley of Kashmir in an over-all partition. 15

India did not concede.

Finally, Dixon proposed himself to prepare a plan of pattition and partial plebiscite, subject to modification, including a provision that the plebiscite area was to be adminlstered by the Unlted Nations through the pleblsclte administrator. Pakistan agreed, but India returned an "emphatic refusal." "The state government would be superseded and to permit Pakistan any role in a plebiscite would be sur:render to aggression. "There can be no equality of any right between India and Pakistan in this or other relevant

14 New Delh1 suggested a pleblscite in the vale and parts of huzaffarabad. Indla would receive all of Jammu east of the cease-fire line and most of Ladakh. Pakistan would acquire Gilgit, Gilgit Agency, Gilgit Wazarat, the Iribal Territory, and Baltistan (all northern districts), and Jammu west of the cease-fire line.

$1950,5 / 1791, \frac{150}{\text { p. } 39}$. 
respects. 16

Dixon admitted failure, for he was convinced that, glven the docility and gentleness of the Kashmiris, Impartial administration of the plebiscite areas was an absolute necessity for a falr plebiscite. He had given up hopo of reconciling Indian demands with a formula for partition and partial plebiscite that would be acceptable to Pakistan. If there remained a posslbility of settlement by agreement, it lay in partition with somelmethod of determining possession, of the Vale other than by an over-all plebiscite. But the idfficulty In partition was determination of an acceptable boundary:

I cloubt whether 1t may not be better to leave the parties to themselves in negotlating terms for the settlement of the problem of how to dispose of Jammu and Kashmir. - So far the attitude of both parties has been to throw the whole responsibility upon the Security Council or its representatives of settling the dispute, notwithstanding, except by agreement between them, there was no means of settling $\$ t .17$

Council consideration of Dixon's report and the additional factor of the constituent assembly resulted in adoption on March 30, 1951 of a resolution sponsored by the United KIngdom and the United States. The Council viewed the assembly as possibly prefudiclal to a plebiscite in:

16Ildd., p. 42. Regarding "surrender to aggression," Nehru said on November 25, 1947: "The issue in Kashnir is whether violence and naked force ishould declde the future. . The ralders encouraged by Pakistan have sought to enforce by the sword accession to Pakistan against the obvious wishes of large numbers of the people. . We cannot permit the success of this method to achleve political ends." Nehru, p. 65.

${ }^{17}$ SC official Records, 5th Year, Supp. for Sept., $1950,5 / 1791$, p. 46. 
Berrinding the Covernments. . of the principle embodied in the Security Counc1l. . - and the United Nations Comnission for India and Pakistan resolutions. . that the final disposition of the State of Jarmu and Kashmir will be made - . through the democratic method of a free... plebiscite. . under the auspices of the United Nations;

Affirming that the convening of a Constituent Assembly. . and any action that Assembly might. . take to determine the future shape and affiliation of the. . State or any part. . would not constitute a disposition of the state in accordance with the above principles. . 18

Dixon's resignation was accepted. A successor would consult with the governments to effect demilitarization on the basis of the commission resolutions of August 13,1943 and January 5. 1949. And the Council:

calls upen the parties, in the event their discussions with the. . Representative falling in his opinion to result in full agreement, to accept arbitration upon all outstanding points of difference reported by the. . Representative. . 19

The cease-fire would continue, and the governments were requested to refrain from action prejudicial to a peaceful settlement. Although India immediately rejected the resolution, It was adopted with eight voting in favor (Brazil, China, Ecuador, France, the Netherlands, Turkey, the United KIngdom, and the United States); none opposed; and three abstentions (India, the Union of Soviet Soclallst Republics, and Yugoslavia).

Activating the resolution, the Council, on Apiril 30 ,

185c eff1cial Recerds ( $5 / 2375), \mathrm{s} / 2017 /$ Rev. 1, p. 38 , 19loc. sit. 
1951, named Dr. Frank P. Graham 20 of the Un1ted States as Dixon's successor. Graham's first report was submitted on October 15, 1951 and covered his activities from June 30 to September 15. He had found a complex situation in the subcontinent. The cease-fire was being imaintained, there had been some decrease in armed forces in Kashmir, and there was a general desire to settle the problem as soon as possible. Disturbing elcments were alleged cease-fire violations on both sides, war-mongering propaganda, and continued activity of the constituent assembly.

On September 7, Graham drafted a twelve-point demilltarization program designed to meet the situation:

The covernments of India and Rakistan

1. . specifically pledge themselves that they will not commit aggression or make war. . with regard to the question of. . Kashmir;

2. Agree that each Covernment. . w1ll instruct its offlcial spokesmen and will urge all its citizens. . not to make. - statements calculated to incite the people of elther nation to make war against the other. . ;

3. Reaffirm their will to observe the cease-fire. :

4. Reaffirm. - the principle that the question of the accession of. . Kashmir. . will be decided through. . a free. - plebiscite under the auspices of the United Nations;

20 Frank Porter Graham, 1886-, former United States senator and president of the University of North Carolina, is one of five American citizens on the United Nations Panel for Inquiry and Conciliation. During the war he served on a number of war boards. Grahan was the American representative on the Good Offices Committee on the Indonesian Question, 1947-48, and was subsequently special adviser to the secretary of state on Indonesian affairs. He was defense manpower administrator in the Department of Labor when named to the Kashnir post. 
5. Agree that. " the demilitarization of - . Koshmir. . vill be effected in a single, continous process:

6. Agree that. . demilitarization shall be completed during perlod of 20 days, unless another period is decided upon by the. . . Covernments. .;

7. Agree that. . at the lend of the period - . the situation will be:

$\dot{A}$. On the pakidtin side of the cease-fire line:

(i) the tribesmen and pakistan nationals

(11) * will have been withdrawn;

(11) the pakistan troops will have been withdrawn from the state, and

(1ii) large-scale. - disarmament of the Azad. - forces will have taken place. B. On the Indian side of the cease-fire line:

(i) the bulk of Indian forces in the State will have been withdrawn;

(ii) further withdrawals or reductions. . of the Indian and State. . forces remaining after completion of the operation referred to in $B(i)$ above will have been carried out;

so that. . . there will remain on the. . Pak1stan side of the. - Iine a force of * Civil Armed Forces, and on the Indian side. . a force of - ${ }^{*}$. Agree that the dorilitarization shall involve no threat to the cease-fire agreement. - ;

9. Agree that representatives of the... Governments. . will. . . draw up a programme of demlitiarization. ;

10. Agre that. demilltarization will be without prejudice to the. - responsibilities of the. . Representative and Plebiscite Administrator with regard to the final disposal of forces. : 11. Agree that differences regarding the programme of demilitarization. . . will be referred to the Milltary Adviser of the. - Representative, and if disagreement continues, to the. . Representative, whose decision shail be final.

(*It is requested that the. . spaces be f1lled in by your Government). 21

Both governments accepted the first four paragraphs.

But for India, withdrawal of Indian troops and disarmament of the Azad forces affected Kashmir's security and could not be

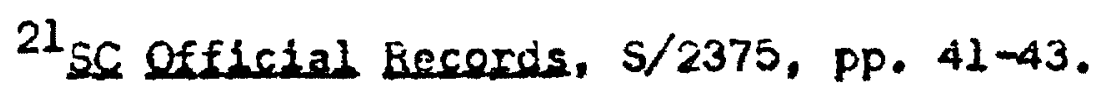


consldered separately. Indla would withdraw the bulk of its forces and some of the remainder provided there was complete demilitarization on the Pakistani side of the line except for a civil force of 4,000, half Azad followers and half not, commanded by United Nations officers or "locals" and not Pakistanis. Pakistan would accept disarmament of azad forces provided the balance of the Indian forces were withdrawn and there were reductions in the state forces.

India thought it premature to appoint the administrator before completion of demilltarization, while Pakistan favored appointment as far in advance of the final day as possible. India termed the 90-iay period insufficient and Pakistan accepted it. In essence. India would ayree to withdrawal only when Pakistani troops, tribesmen, and Azad forces no longer could be consldered a menace to security. The exact period and phasing of withorawal and the size of forces to remaln could not yet be determined. Pakistan assented to ihe provisions as they stood but continued to insist upon "military balance" on either side of the cease-flre line. Graham recommended that the Council call upon the governments to avoid increases in their military forces in Kashmir and to renew efforts at agreement on demilitarization.

The Counc11, in a United Kingdom-United States sponsored resolution aciopted on November 10, 1951, approved the demilitarization proposals and:

2. Instructs the. . Representative to continue his efforts to obtain. . demilitarization. . : 
4. Instructs the. . Representative to report to the Security Council on his efforts. . not later than six weeks after this resolution comes into effect. 22

Graham reported again on December 18, 1951. His program during renewed negotlations had been: (1) to exhaust possibllitles of agreement on previous proposals for dem1l1tarization and (2) in case there was no agreement, to obtain detailed plans from both parties in order to establish points of difference. From the outset he had concentrated on narrowIng disagreement on the size of forces to remain after demil1tarlzation and on appointment of the administrator, but differences had remained essentially the same. However, he was able to report agreement on four additional paragraphs, 8,9 , 11. and 12--covering, respectively, the cease-fire agreement, drafting of demilitarization detalls, responsibilities of the representative and administrator, and arbitration. India accepted the last on condition that it concerned technical detalis in implementation of the agreed program, not differences arising in the process of drafting.

But as agreement had not been reached on the remaining four, most basic, paragraphs covering continuous demilitarization, the 90-day perlod, phasing of withdrawal, and appointment of the administrator, Graham recomnended substitution of an absolute deadine of July 15, 1952 and addition of the following phrase to the withdrawal-perlod paragraph: - . so that on the date referred to. . there 
will remain on each side of the cease-fire line the lowest possible number of armed forces based In proportion on the number of. . Forces existing on each side of the. . Iine on 1 January 1949.23

Concerning the other paragraphs, the governments were asked their opinions on reduction of forces and employment of Unfted Nations troops to maintaln security. Pakistan replied that it would be willing to reduce 1 ts forces to any level provided there existed a "balance" between. Incian and Azad forces and that it would accept outside forces. India refused to conslder Unlted Nations troops and noted that further troop reductions would be dependent upon conditions:

Demilitarization concerns only the Indlan and State forces; the State Milltia which is a police force clearly does not fall within either category. 24

Graham found that there had been no substant1al change in positions. Demilitarization presented insurmountable obstacles unless agreement were reached on a definite period for demilitarization, the scope of the program and the number of troops to remain in Kashmir, and appointment of the admin1strator, whIch was the keystone of the entIre program; "the clearest symbol both of. . Ultimate demilitarization and the promised plebisclte, would be. . a definite day for induction into office of the. . Administrator." 25

The Counc1l, without formal vote, approved continua-

${ }^{23}$ sc official Records, s/2448, p. 13. 24 Ib1d. . p. 47. 25Sc officlal Becords, 7th Year, 570th keeting, p. 9. 
tion of Graham's activities, and on April 22, 1952 his third report was submitted. He was of the oplnion that of the three parts of the commission's truce proposals, upon which all demilltarization attempts had been based, the cease-fire was largely implemented, and to all practical purposes the truce was in operation without formal agreement. The Counc1l and the representative should henceforth cievote their efforts to the third phase, the plebiscite itself.

But there had been little change in the positions of Karachi and New Delh1. Indla was adamant on the question of withdrawal, although willing at the conclusion of demilitarization to consult with the administrator and the representative on further reductions in its forces. The remaining issues could be settled easily once the scope of demilitarization and the size of forces to remaln had been decided.

Paklstan accepted the date of July 15, 1952 and agreed that demilitarization should embrace all armed forces in Kashmir without exception:

There is no justification whatsoever for the contention that the State Militia is a police force and so not llable to disbandment, 20

The militia was organized along lines of the Indian infantry and was officered by Indians. Indla had not objected when the McNaughton and Dixon proposals referred to the militia in connection with the state army and the Azad forces. But arbitration of "technical differences" was not sufficlent;

${ }^{26}$ sc official Becords, s/2448, p. 33. 
there should be a provision, sinllar to that of the March 14, 1950 Council resolution, authorizing the representative to "Interpret" agreements reached on demilitarization. "The experlence of the last three years underlines the necesisity for such a provision. Without it, there would be no means of resolving deadlocks that might ar1se." 27

\section{II}

Seven issues summoned the Indian and Pakistanf champions into battle during the most recent phase of the Kashmir dispute. The controversy over the constituent assembly was the first to arise. In Pakistan's view, convening of the body nullified the "International agreement" resulting from acceptance of the commission resolutions of August 13, 1948 and January 5, 1949 and was a challenge to the author1ty of the Security Councll.

Rau fell back on the legal basis of India's federal structure. Kashm1r was a unlt of the Indian federation, largely autonomous and ent1tled to frame 1ts own constitution. The main purpose of the assembly was to provide for an elected legislature with a responsible executive:

So far as the Government of India is concerned, the Constituent Assembly is not intended to prefudice the issues before the Security Counc1l, or to come in its way. 28

The assembly might express an opinion on accession, but it

27 Ibid. p. 36.

${ }^{28}$ Sc efficlal Records, 6th Year, 533rd Meeting, p. 6. 
could make ho declsions.

Zafrullah Khan saw the shadow of consplracy. The assembly, a result of a long-considered scheme, was a clear Indication that India had never intended to proceed with a plebiscite. If a referendum at an early date were to determine accession, there was no need for an assembly to frame Kashmir's constitution:

The proposed consituent assembly 1s. . . an attempt on India's part to contrive yet another pseuco-legalistic subterfuge to cover its occupation of Kashmir. . against the will of the people. - We are not convinced that the. . assembly is not an attempt to confuse the issues, poison the atmosphere and obstruct a just and peaceful solution. And. - we are not convinced that. - Indla can be absolved of 1 ts full responsibility in this matter by any attempt on its part theoretically to separateithe so-called autonomous sphere of "the liaharaja's Government from India's own sphere of authority. 29

The second point to assume importance touched many of the differences and agreements comprising the history of the dispute. Both parties accused the other of Fallure to fulfil obligations. Rau heatedily denfed the charge. On analysis, India's "so-called intransigance" would be found to be nothing more than rellance upon "pledges already given to Ind1a." Actually, sald Rau, India had more than met its obligations. Without awaiting a truce and demilitarization agreement, India had reduced its forces desplte previous understandings which called for prlor Pakistani action. On the other hand, Pakistanl troops remalned in Kashmir although they had accomplished

${ }^{29}$ SC Official Recerds, 6th Year, 548th Meeting. p. 9. 
their supposed goal--forestalling of an Indian offensive and prevention of a faft accomol1. And India had not forgotten

its promise of a pleoiscites

Unfortunately, the soll of Kashmir has not yet been cleared of the invader--the Pakistan Army which joined the invader is still there--and so the fulfiliment of the wish of the Government of India has been delayed by Pakistan's own act. 30

Zafrullah Khan turned to the issue of the Azad forces for his reply. Pakistan had never repudlated its obligation to withdraw its forces, but Indian insistence upon Azad disbandment without prefudice to state forces had proved a real obstacle. And Indian refusal to consider employment of neutral forces blocked a possible solution to the impasse. No matter what India offered in the way of justiflcation for this attitude. Pakistan could not consider withdrawal unt1l definite procedures were agreed upon and fulfilled by India.

The Dixon report introduced several 1ssues. Regarding Council abandonment of responslbility for the dispute, Rau thought worse programs might be adopted than allowing the Inftlative to pass back to India and Fak1stan. Zafrullah Khan was far from agreement, for he belleved the situation required vigorous and immediate action. The result of Counc1l renunciation of jurisdiction might not be pleasant:

It would enable Indla to consolidate its hold on Kashmir and to continue systematically to alter the composition of the population by forcing or driving out more and more Muslims as refuyees

${ }^{30}$ SC Officlal Recerds, 6th Year, 538th Meeting, p. 2. 
into Pakistan, and settling non-Muslims in their place.31

On the possibility of a partition-plebiscite arrangement providing solution, Rau repeated to the Council Indla's vlew as expressed to Dixon. New Delhl was prepared to consider the proposal providing a major share of disputed territory were arbitrarily awarded to India. Pakistan, unwilling to accept a combination, would agree to simple partition if the vale were to be part of its share.

On the possible employment of foreign troops during the plebiscite period, Pakistan was in agreement. In fact, Zafrullain Khan pointed out, as long ago as January, 1943 he had acquiesced in the use of Comnonwealth or United Nations troops.32 Rau again took refuge in Kashmir's "soverelgnty" and "integrity." Foreign troops were "unthinkable," for they would amount to Interference with the functions of Kashmir's lawful government:

We are wholly unable to accept any entry of foreign troops in the State or in any other part of India; . . In view of the provision made by the resolutions of August 1943 and January 1949. there is no occasion for the use of foreign troops or of special local levies recruited by an outside agency. 33

The unchanging attitude of the Council members toward

31 sc Officlal Becerds, 6th Year, 535th kieeting, p. 7. 32 see page 45.

335c official Becerds, Eth Year, 536th dieeting, p. 4. The provision referred to covers employment, in consultation with the commission, of Indian troops to maintain order and security. 
arbitration may possibly have influenced India's capitulation on this issue during the Graham negotiations. But in the debates on the Dixon report, Rau was unyielding, stubbornly vlewing all suggestions as proposals to reopen questions settled by resolution or agreement.

Zafrullah Khan delighted in this opportunity to cast1gate the Indian approach to international cooperation. How any nation which thought its cause just could refuse impartial adjudication was beyond his comprehension. He struck at Indian sensitivity on the resurrection of past controversles:

It was not suggested that the accession of. . Kashmis. . . should be submitted to arbitration. The suggestion is: as there is an international agreement embodied in the two resolutions of 13 August 1948 and 5 January 1949, and as the implementation of these resolutions has come to a standstill, the issues arising therefrom should be submitted to arbitration so that the arbitrators can determine what is to be done. 34

The final issue, Graham's proposals on demilitarization, the withdrawal period, and the administrator's appointment, was only fleetingly touched, for positions had been made clear to the representative and negotiations were then in progress. Yet there were hints of incipient agreement, for India's Setalvad saw little difficulty in settling the withdrawal period and the administrator's appointment provided agreements were first reached on the scope of demilltarization and the slze of residue forces. As a gesture toward a soluion, Setalvad produced new Indian offer, 6,000 men below

34 Ibid. . P. 9. 
10 original flgure, on condition an additional 6,000-man . Itta be regarded as an internal police force, not a miliIry reserve. Azad territory would be garrisoned by a 4,000in force, only half of which should consist of Azad adherents. Zafrullah Khan was not as yet amenable to any scheme - far removed from a "military balance" and continued to iess for early induction into office of the administrator:

Pakistan is. . ready to carry out. . demilltarization in two stages. . . or a. . . programme in one single continuous process. . But Pak1stan could not possibly be expected to agree to any one-sided. - arrangement. For us, demil1tarization is not an end in itself; it is an essential preliminary to. . . free.. . plebiscite. 35

The only real differences among the majority of Coun11 members during this final period lay in the zeal with ilch they pressed for a settlement. All but the Sovlet ifon approved both the Dixon and Graham reports. All were itical of the constituent assembly and of India's refusal , compromise on demilitarization terms. The lone conflict rose when Jacob Malik36 of the Soviet Union crlticized the sthod of Graham's appointment and his procedures, but not is conclusions or recommendations.

Francis Lacoste 37 of France belleved a plebiscite,

35sc official Records, 7th Year, 571st Meeting,p. 6.

$36 \mathrm{Jacob}$ A. Malik, 1906-, entered diplomatic work in he press section of the Soviet forelgn office. He attended he Five-Power conference in 1945, was political adviser to he Soviet representative on the Allied Control Council in 746. and has been permanent representative to the Unlted ations since 1948.

37 Francis Lacoste, 1905-, has served the Guai 
essential to settlement, required fulfilment of one condition -plebiscite territory must be free of influences "such as that inevitably involved in the presence of occupation troops -. belonging to one. . of the partles concerned."38 Demilltarlzation was thus a prerequisite:

States like Indla and Pakistan owe it to the international community, and to themselves, to demonstrate their policital maturity. . . The draft resolution. . does not ask the parties to sacrifice principles, ideas or even interests. It does no more than ask them to apply. . . classical methods. . recommended for three years by the Council as the best means--if not, in the absence of direct agreement, the only means--of escaplng from what seems. . . to be assuming. - the appearance of a dangerous impasse. 39

Mal1k broke four years of Soviet near-silence only to Ignore the dispute in order to criticize United Kingdom and United States activities. He thought it strange that only one candidate to succeed Dixon was presented, and this candidate an Amerlcan. In the more than four years since the dispute had been 1ntroduced, the western power's had been partlcularly active. Resolutions had been adopted, commissions established, and representatives appointed, but no real progress toward a settlement had resulted. Malik suspected plans of an "annexationist, Imperiallst" nature:

They are not based on an effort to achieve a real

d'Orsay In Paris, Belgrade, Peking, and Washington, with the Free French Forces of the Interior in 1944, he has been a cielegate to the United Nations since 1948.

${ }^{38}$ Sc Officlal Becerds, 6th Year, 539th Meeting, p. 5. 39 Ibid. P. 6. 
settlement. . They pursue different alms, different--directly contrary--objectives. The purpose. . Is interference. . In the internal affairs of Kashmir, the prolongation of the dispute. . . and the conversion of Kashmir into a protectorate of the United States and the United KIngdom. . Finally, the purpose... Is to secure the introduction of Anglo-American troops. . and convert Kashmir into. . . m111tary and strateglc base. 40

In addition, the American representative had pressed the governments to accept foreign troops, although the Counc1l had not authorized him to do so. Sir Gladwyn Jebb4l of the Unlted Kingdom informed Mal1k that if the Counc1l were ever to accomplish anything, It must rise above the "low-lying polsonous mists of susplcion" that had so often defeated it. Further, Malik's charges were ridiculous and thoroughly unbellevable:

No doubt there are people who can be persuaded to belleve this, just as there are people who could belleve that. - a mission to Antartica to study the habits of penguins could only be an Indirect slander on totalitarianism or on Marxist soclety. It is possible to belleve that; and people. . can always be found who w11l

\section{${ }^{40}$ SC Official Records, 7th Year, 570th Meeting,} pp. 13-14. Malik implied Pakistan had attempted to purchase western support with bases. Pakistan denled this. A rumor, clrculated immediately following partition, had Paklstan offering Chittagong, the best port in Eaxt Bengal, to the United States as a naval base. The New York Ilmes, October 13, 1947.

${ }^{41}$ Sir Gladwyn Jebb, 1900was minister of economic warfare in Britain's wartime cablnet, 1940-42. He attencled the Quebec, Calro, and Ieheran conferences and was acting secretary general of the United Nations in 1946. Jebb helped draft peace treaties with Italy, Hungary, Rumania, Bulgaria, and Finland. He has been permanent representative to the United Nations since 1949. 
believe anything. 42

On Kashmir 1tself, the Undted Kingdom position was comfortably in line with that of the majority of the counc1l. Jebb turmed India's reception of demilitarization proposals "a little less than fair" and thought arbitration was the key to this 1ssue, which in itself was the key to a plebiscite. The United Kingdom felt "very strongly" that the time was past for mediation and persuaslon:

The dispute is not one which time will. . solve - I hope that the Council will accept. . arbitration. - as the most effective way of moving forward towards a settlement. 43

Jebb expressed grave doubts as to the wisdom of calling the constituent assembly, attaching "great importance" to assurances that it was not competent to decide accession or to "prejudice the position" of the Counc1l.

Cross of the United States also saw arbitration as the key and similarly questioned the intentions of the assembly, particularly as relating to India's interpretation of the plebiscite provision in the accession agreement:

That commitment is not.. " to give the people the right to decide whether they would remain In India or not." To phrase the plebiscite question in this form would be to disregard the binding agreement accepted by both parties. The Security Council has from the beginning held that the 1ssue of accession is one which is to be settled by a falr. . plebiscite under United Nations auspices, and both parties, in the language of their own commitments, have accepted

42 sc effictal Records, 7th Year, 570th Meeting, p. 19. ${ }^{43}$ sc efficial Records, 6th Year, 566th Meeting, p. 3. 
this view. 44

\section{III}

The commission's faith in the "flexibllity" of an approach to the problem by a single United Nat1ons representative has been substantiated to a great extent by the accomplishments of the Security Councll's two representatives. As a result of their activities, and of time, the issues dividIng Indla and Pakistan are no longer so numerous or so vital. A cease-fire in Kashmir has been maintained for some time, and a truce, the second part of the commission's comprehensive settlement proposal, for all practical purposes has been implemented. Sir Owen Dixon's acceptance of the Indian contentions regarding the invasion as a violation of international law, while not acted upon, have partlally mollifled Indla on th1s issue. Dr. Frank Graham's twelve-point truce program has $a 11$ but found acceptance. The introduction of the principle of proportional residue forces in Kashmir has pointed a way to a solution of a portion of the withdrawal question. And, most important, limited acceptance of arbitration has removed many of the difficulties surrounding demilitarization. Yet 1ssues remain. The scope of and size of forces to remain after withdrawal are still in contention. And to "military balance" and "synchronization" as factors in this problem, has been added the status of the Kashmiri militia. The exact perlod during which withdrawal is to be completed 
is st111 undecided as is the date of official appointment of the plebiscite administrator. The parties continue to be divided on employment of outside forces during the plebiscite period, and the existence of the constituent assembly is a festering sore. The question of an interim administration has again arisen. And on the most promising formula for a flnal settlement, partition and a partial plebiscite, the demands of both parties are unacceptable to the other.

Eut once these problems are recognized as the technicalities that they are, the present Kashmirl plcture appears brighter than at any time during the history of the dispute. As the United Nations representative continues his slow but increasingly successful progress toward bringing India and Pakistan together on the remaining detalls of the demllitar1zation program, there is reason for hope that a settlement may yet be achieved on the twin plllars of his twelve-point program and acceptance of some plan of partial plebiscite and partition.

Rhetorically, Indian and Pakistanl arguments appear to have changed but slightly since the inception of the dispute. To India, it was and is a question of international law, the violation of international obligations; to Pakistan, a question of unlawful occupation of Kashmir and of thwarting the desire of the people to express their political preference. But beneath the surface, and in many instances quite cleatly, both governments tend increasingly to adopt a realistic approach and to accept the situation as it exists, 
not as theory outlines it. Thus India, although continuing to place the greatest stress upon the inviolability of Kashmir soverelgnty, has, for all practical purposes, abandoned hope or Intention of occupying all of Kashmis during the plebiscite period. And Pakistan is amenable to a preponderance of Indian forces in the state, though not yet so great as Indla demands. Both parties, In action if not in words, have come far desertIng an absolute approach for compromise and practicallty.

The Counc1l voting record has followed the pattern firmly established in previous periods. Attitudes rarely show partiality; the desire is to settle the question in almost any fashion capable of winning approval from both governments. Where fakistan had been universally reoroved for its action in moving troops into Kashmir. India was similarly reprimanded on the issue of the constituent assembly and on its picayunish approach to demilitarization. And the United Kingdom and the United States continue to lead the Council in quest of an answer to the problem of Kashmir.

The detached Council attitude precludes a distinct advantage for either party. Pakistan's great success came earliex in being accepted as a legitimate party to the dispute. Indications that the various settlement proposals favored Pakistan were only apparent, for Pakistan may better afford to accept any proposal which does not grant India a decided advantage. India yet finds it difficult to accept certain essential provisions without abandoning completely the original basis of its case. 


\section{CHAPTER VII}

\section{SIGNIFICANCE}

For the observer who cuts beneath a surface of repet1tive arguments and Intransigant positions, the problem of Kashmir presents several questions concerning its significance, for India and Pakistan and for the Security Council. Logical answers are possible only through an understanding of the dispute 1tself. Kashmir did not spring full-grown upon the world scene. Its slow generation lies in history, deep in the turbulent past of Indial and in the chaotic history of the modern international community.

Of vital Importance is the character of modern India, the result of centuries of change and conflict in the subcontinent. An apparently irresistible attraction for conquerers throughout recorded history has precluded development of an homogeneous character. Invasions have piled successive layers of culture upon the land unt1l it has become a welter of people and races, religlons and sects, philosophles of government and ways of 11fe. The British, and the Noguls before them, imposed a surface political unity upon the

IIn this case, "India" refers to both the Indian Union and Pakistan.

$$
-158-
$$


sub-continent. But always there remalned many Indias. Two facets of pre-independence Indla--its religlous cleavage and Its political anatomy--resulting from the confused past contributed directly to the dispute that is Kashmir.

India in political flux at the conclusion of the Second World war was scarred by conflict between two great falths. Three hundred million Hindus and one hundred million Moslems had radically different ldeas as to the structure of an independent state. A solution was sought through the establishment of two nations, Pakistan as a Moslem homeland and the Indian Union as a secular state. Though perhaps a political solution, partition did not result in reconclilation of religlous antagonism, which continued to corrupt relations between the new governments.

As repeated invasions aided in generating Indla's religlous difficulties, so they created complex political configuration which had few equals. Under the British, long masters at construction and administration of complicated governmental systems, the intermingling of sovereign states and British provinces was not a barrier but an actual aid to domination. But when Great Britain relinquished power in Indla, the exact status of the principalities could no longer be considered of importance in theory alone. Two successor states, imbued with modern nationalism, were not inclined to permit continuation of a ritualistic political hierarchy challenging their own authority over the millions of the subcontient. The problem became immediate with partition and 
Independence and found rough solution in the rush of events. Yet in cases where religious animosities merged with political complexities, serious complications were inevitable.

Granted a background composed of unlque religlous and political elements, the problem of the states might have been solved without serious difficulty had there been sufflcient time to seek a solution through negotiation and compromise. But precipitate British withdrawal precluded lelsurely consideration of the issue; the question of the future of the states was thrown into the arena, to be answered by circumstances rather than reason.

The character of the governments involved has had much influence in prolongation of a dispute thus engendered. Independence day on August 15, 1947 saw two new commonwealths rise from the defunct Indian Empire. Pakistan is a nation frankly based upon theology. Thersense of religlous singularIty is coupled with the pride of new nation and the fear of domination by the remaining great bulk of the sub-continent. All combine to give the Pakistani government a character fanatic, nationalistic, and sensitive to any apparent challenge of its rights.

The creators of the Indian Union, on the other hand, are determined that $1 t$ will be a secular state. They have lost the battle of communalism and partition in Indla as a whole but are dedicated to the proposition that the territory remaining to them will not be marked as an exclusively Hindi pollty. Already possessing a large hoslem minority popula- 
tion. India is able to view the acquisition of more Moslems In Kashmir, part1cularly if the people voluntarily refect communallsm and Indicate preference for a secular though Hindu-majority state, as furthering this program. In additIon, Indla's leaders are almost without exception rarified Intellectuals, usudily educated in law, immersed in the technicalities of abstract theory, and idealistic. The result is a government which, in a case such as Kashmir, may be depended upon to stress the letter of International law, which is susplclous of the motives of a government that has destroyed the drean of a unlfied secular sub-continent, and which will take umbrage at the slightest impugning of 1ts own motives.

\section{II}

From th1s situation 1ssues the Kashmir dispute, a disturbance initiated by tribal invasion but which soon involved both dominions. Although neither government desired open conflict, public excitement, nurtured on bitterness resulting from partition and recent communal bloodshed, was capable of producing a situation in which, reason overwhelmed by emotion, India and Pakistan would plunge into war.

Initial Indian and Pakistani attitudes were dogmatic. India viewed the tribal incursion and alleged aid furnished by Pakistan as violations of international law which would have to be punished, whatever the other aspects of the situation. Accession was legal and India's actions were legitimate and understandable. Nehru defended the Indlan record one week following accesslon: 
I want to say at once that every step that we have taken in regard to Kashmir has been taken after the fullest thought and consideration of the consequences and I an convinced that what we have done was the right thing. Not to have taken those steps would have been a betrayal of a trust and cowardly submission to the law of the sword with 1ts accompaniment of arson, rape and slaughter. 2

But Pakistan saw in India's acceptance of Kashmir's accession 8 violation of the meaning of partition and an attack upon the security of Moslems and of Pakistan. Denying all charges of complicity in the invasion, Pakistan refused to recognize elther accession or the legality of Indian mil1tary operations in Kashmir.

Equally important in influencing the later course of the dispute is the character of the Security Council itself. Two years following its establishment, it was already clear that the Council was not a unified body able to cope efficiertly with major international disturbances:

The Council's particular job is to listen to any nation, whether a member or not, which thinks it is being imposed upon enought by another nation to threaten the peace. The councli has the further job of deciding what action to take in such arguments. 3

The Council is capable of fulfilling its flrst function as a forum for debate. But on the second, internal division prevents resolute action. The Counc1l is uncertain as to the exact line between suggestion of action and impos1tion of its will, which it is unable to back vith force. It

2 Nehru, p. 55.

3 Sigrid Arne, A United Nations Eximer (New York: Rhinehart and Company, 1948), p. 216. 
is clear that the Council cannot function as an international board of adjudication, returning decisions based solely on law and fact:

The Security Counc1l has in no case any aythority to settle a dispute with binding force. Fence it can never exercise any activities having the character of. . arbitration, but at most make non-binding recommendations, i.e. mediate. 4

The Council must attempt to bring the parties together on a compromise program which will ensure cooperation in effecting a settlement. Without voluntary participation of the states involved, a proposal would be valueless.

An approach such as this inevitably led to frequent abandonment of legal 1ight. Rather than treating the Indian complaint as a legal charge, the Council indicated its intention to consider the practical aspects of the situation and to seek a compromise solution. This could be accomplished through two methods: "The Security Counc1l may either recommend procedures or methods of adjustment or recommend directly the terms, . . the basis of a settlement." 5 Both procedures were followed, the first in authorization of conversations between the parties with the Councll president as sapperteur and in the later suggestion of arbitration of demilltarization df ferences; the second in adoption of a cease-fire, demilitarization, and a plebiscite as the principles upon istich a settlement should be based.

${ }^{4}$ Alf Ross, Constituion of the United Nations: Analysis of Structure and Eunction (New York: Rhinehart, 1950), p. 156.

5Alexandre Farodi, "Peaceful Scttlement of Disputes," Internatienal cencillation. CDXLV (November, 1948), p. 622. 
The task of the United Nations Commission for India and Pakistan was to develop detall for implementations of the agreed-upon principles. Commission activities resulted in a cease-fire and acceptance of general demilitarization plans. But differing interpretations of certain detalls of the formula blocked further progress by the commission and led to its dissolution and replacement by a single United Nations representative. Two successive representatives have maneuvered India and Pak1stan closer to a settlement. Although no agreement has been slgned, long months of qulet have so cooled initial passlons that a de facte truce exists. And only three technical differences obstruct agreement on plebiscite prerequisites on the basis of Graham's twelve-point program. In the process of negotiations. India and Pakistan gradually have abandoned their Initial dogmatic positions; they are inclined to accept conditions which would have been repugnant in the flrst months of the dispute. With Increasingly serious consideration of a settlement proposal based upon both partition and a plebiscite. the Council may yet find a formula which will satisfy both partles to the dispute. It would appear that Francis Lacoste, the Counc1l representative of France, was overly pessimistic in his opinion expressed to the Council on Narch 30, 1951:

Year by year the eloquence and skill of the representatives of India and Pakistan seem to ralse new aspects of the subject. However, a calm study of their speeches and of the practical results they have each year achieved, leads to the dual conclusion that. In the realm of Ideas, the Counc1l has had no occasion to change its position. . and that, so far as the facts are concerned. there has unfortunately been no roal 
progress towards a settlement of the dispute. 6

Although the final form and date of a solution remain uncertain, a number of possible settlements may be examined. Least l1kely, nearly five years after violation of a mountain border threatened conflict in Asia, is war. As The New Yerk Iimes remarked editorially:

The Security Council has been at this problem for more than four years, during which time there has been only one positive achievement-the establishment of a cease-fire line.. However, there has been a negative achievement that far surpasses any other feature of this case-war between India and Fakistan over Kashmir has been avoided. 7 .

An only slightly less remote possibility is an independent Kashmir, friendly to both dominions but controlled by nelther. While it is undoubtedly true that many Kashmiris, even members of Sheikh Abdullah's government, nurture hope of complete independence, 8 it is highly unlikely that elther New Delhi or Karach1 would give it serlous consideration.

The dispute may yet be settled according to the original formula, an all-inclusive plebiscite. But considerIng the impasse on plebiscite conditions and recent favorable attitudes toward total or partial partition, this possibility appears to be rapldiy losing its appeal.

The possibility of total stalemate cannot be overlooked. If the Council were to adopt Sir Qwen Dixon's

${ }^{6}$ SC Qfficial Records, 6th Year, 539th Meeting, p. 4.

${ }^{7}$ The Naw Yerk Times, April 23, 1952.

IIbid. . February 3, 2052. 
suggestion that the initiative be returned to Indla and Pakistan, such could very likely be the result, for the governments displayed no ability to negotiate a solution when they possessed the initiative before the introduction of the dispute into the Security Council.

A simple partition of Kashmir between India and Pakistan along the present cease-fire line, now beginning to assume the characteristics of a political boundary, may be regarded as a practical, if not an entirely satisfactory, solut1on. But controversy over possession of the Vale of Kashmir effectively blocks agreement along this ine.

Lastly, a solution may result from the proposal to partition most of Kashmir according to the obvious wishes of the inhabitants with plebiscites to be conducted in doubtful areas. Although Zafrullah Khan informed the commission in 1948 that "under no circumstances" would Pakistan consider any form of partition ${ }^{9}$ and Nehru rejected arbltrary division on religious or any other principle in 1947,10 in June, 1952 plebiscite and partition appeared to be the most likely answer to the problem. Within recent months, both partles have expressed willingness to consider partition--provided they were awared the Vale of Kashmir--and India has assented to a comb1nation of plebiscite and partition, although advancing demands p. 93.

${ }^{9}$ Se Official Recerds, 3rd Year, Supp. for Nov., 1948,

10Vera M. Dean, "Impact of the 1947 Partition Darkens India's Outlook," Eereign Rolicy Bulletin, XXX (November 17, 1950). p. 2 . 
as yet unacceptable to efther the Council or Pakistan. But If New Delhi and Karachi are able to agree upon which areas are to be favored by a plebiscite, not an impossibility, a solution according to this formula may be achieved.

\section{III}

There is more significance, for India, Pakistan, and the Security Council, in the Kashmir question than is usually the case in a territorial dispute. India and Pakistan clearly have shown Increased stature in their approaches to the problem durling five years of negotiations. Although both partles continue to pay verbal homage to their orlginal positions, in practice they have adopted a more realistlc attltude than was apparent in the early days of wildly inflamnatory accusations. They appear to have realized that compromise on position or principle does not necessarily involve abandonment.

The New York Iimes is much too harsh in noting:

So far as the attitudes of India and Pakistan are concerned, Impartial outsiders have been given no reason to change the opinion that has been held ever since the Unlted Nations started 1ts efforts at mediation. India must be condemned. Paklstan has at all times showed a willingness to accept United Nations proposals and Indla has with equal consistency elther rejected them or made unreasonable conditions, 11

The IImes overlooks India's acceptance of the joint plebiscite and partition formula, rejected by Pakistan. And Pakistan has been in a better position to assent to other proposals, for each tacitly or openly recognized the legitimacy of Paki-

\section{1the New York Times, Fpri1 28, 1952.}


stanl participation In Kashmir's affairs. In most instances, Pakistan has everything to gain by acceptance.

For Ind1a, Counc1l, commission, and representative suggestions involved nullification of a portion of the legal framework upon which the Indian case rests. This process is certain to be slow and painful. That India eventually did accede to most major proposals is an indication of how great a change time has produced in the Indiane approach to the dispute.

With cynicism toward international cooperation in control of the public mind after six years of half-peace, halfwar in world affalrs, it is popular to depreclate the Counc1l on all counts, in all cases. Such an attitude is not just to the Council record on Kashmir. Four years of patlent listenIng and proposals have carrled India and Pakistan close to agreement. Even supposing progress were the result of time and exhaustion, the council has contributed nevertheless in continuing negotiations and in forestalling war in the init1al stages of the controversy. The Counc1l, or 1ts agents, brought agreement from India and Fakistan on a plebiscite as the solution to the dispute, on a cease-fire, and on general demilitarization provisions.

Study of the internal workings of the Security Counc1l during consideration of the Kashmir question discloses several interesting points. The members acted with almost total impartlality toward Indla and Pakistan. Although in the early otages of discussion Afgentina and Syria appeared nore 
receptive to Pakistani axguments and at one point the Chinese delegate spoke out in defense of India, there has been no forthright champloning of one party or the other, and touches of favoritism but imperceptibly have affected Counc1l action, as revealed in resolutions. The majority has been resolutely neutral throughout; deviations clearly have been the result of personal oplnion rather than alignments of opposing forces within the Counc1l.

Even the East-West split, which has insinuated Itself into almost every situation to fall under Counc1l scrutiny, has been a negligible factor in consideration of the Kashmir dispute. 12 At no point has the veto power come into operation. Soviet abstention from resolution votes indicates lack of Interest rather than opposition to majority pollcles. Although United Kingdom and United States diplomatic activity outside the Security Council drew flre from both the Sovlet Union and Pakistan and Indications of it appeared in several resolutions, efforts appear to have been in furtherance of Council policy rather than attempts to clrcumvent the internat1onal agency.

Coupled with this evidence that the Counc1l is capable of functloning as an impartial mediator, a settlement, not too long delayed, may yet contribute toward recouping some of the Counc1l's prestige, diminished by slight success in

12 Although the USSR publicly announced support of India in late 1951, the move has had no apparent influence upon councll attitudes and actions during consideration of the dispute in 1952. 
other disputes. A satisfactory solution could demonstrate that the Council, although as now constituted incapable of fulfilling the high hopes once held for 1t, can function effectively as a concillatory agency in the itype of dispute for which it was intended, a situation not complicated by the unprovided for great-power rivalry. Graham notad this possibility in his third report:

The intellectual, political, and spiritual leaders of India and Pakistan have the most strategic opportunity through the settlement of a complex and stubborn dispute to give to the United Nations and to the peoples of the world a desperately needed example of Interna-
tlonal cooperation for freedom. . and peace.

Activities and achievements in the Kashmir question add no new facet to the known character of the Counc1l. Despite over-enthusiastic expectations in certain quarters, the Security Counc1l does not pretend to be the resolver of all International difficulties, the bearer of the millenium in International affalrs. W1thout clear authority of 1ts own and sufficlent force to buttress that power, it is unable to function as an International arbiter. The Councll was conceived as more of mediating agency to which international difficulties may be carrled for discussion and settlement. But even this interpretation of the Counc1l's role rests on the hope that the great powers can cooperate, avoidIng alignment in rival factions. Any organization acceptable to the nations whose membership is essential can never prepp. $23-25$.

13 sc Official Records, 5th Year, 564th Meeting, 
vall in the face of determined opposition of any great power or reconclle a serious dispute among great powers. It is obvious that the Counc1l, following the fallure of this hope, cannot function effectively while split into contending factions. But, as T. F. Tslang noted, it can yet perform a service:

What, then, can the United Nations contribute towards the malntenance of peace? It has no force of 1 ts own. It has no financial resources of its own. Some of the important problems of the world are not within the scope of 1ts activities. . In the face of all these linitations and difficulties there is one sphere where we can be useful and strong. That is the sphere of world public opinion. It is by moblilization of the moral forces of the world that the United Nations today can make a real contribution. I am firmly convinced that if we should be courageous enough to deploy all the moral forces of the world, we could yet maintain the peace of the world. 14

Although Islang's view is perhaps overly 1dealistic, the Security Council does provide a forum by means of which states may release tensions which threaten hostilities. The Kashmir question is an example. "Dr. Graham obviously feels that if he and the disputants. - keep on talking, nothing drastic will happen, and perhaps time. . will bring. . a solution." 15

The Securlty Council, as the United Nations organ primarily responsible for world peace and securlty, may yet contribute to some degree of International stability. Graham Is of this opinion:

${ }^{14}$ SG officlel Recerds, 5th Year, 471 st Meeting, p. 14. 15The Lew Yerk Iines. April 23, 1952. 
The United Nations, with all its growing pains and frustrations, is the only international body for the settlement of the most difficult international disputes. The failure of peaceful settlement of such deep disputes has involved the world in tragedies too terrible to risk again. The United Nations, with all its defects, 18 nevertheless, with its multilateral procedures for the peaceful settlement of complex disputes, stif $\frac{1}{6}$ the best hope of the peoples for peace. 16

16 SC Official Records, 6th Year, 564th Meeting, pp. $23-25$. 


\section{BIBLIOGRAPHY}


PRIMARY SOURCES

United Nations, Security Counc11. Official Records. Th1rd Year, January-December, 1948, United Nations Secretarlat. Year, Januáry-December, 1949, United Nations Secretariat.

Y Y

Year, January-December, 1950, United Nations Secretariat.

Year, January-Becember, 1951', United Nations Secretariat.

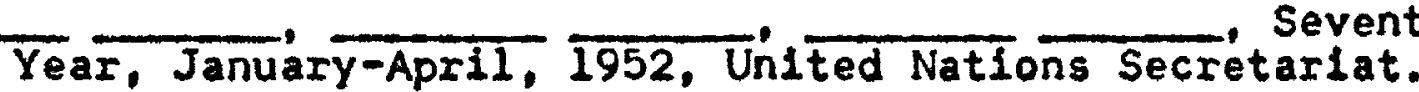

- Beport

by Dr. Erank 2. Graham, United Nations Bepresentative for India and Pakistan, to the Security councll, S/2375, 15 October, 1951, United Nations Secretarlat, Department of Public Information.

Beport by Dr. Erank 2. Graham, Unjted Nations Representative for India and Pakistan, to the Security Council. S/2448, 19 December 1951, United Nations Secretariat, Department of Public Information.

Report of Dr. Erank R. Graham, United Nations Bepresentative for India and Pakistan, to the Security council. S/2611, 22 April 1952, United Nations Secretariat, Department of Public Information.

Without the Security Councll proceedings, containing verbatim transcripts of debates on and resolutions concerning Kashmir, this study could not have been centered upon the Security Council 1tself. Although incomplete for several periods, the Records furnished most of the material for the chapters covering the activities of the Council. the commission, and the two representatives in the Kashmir question. The Becords often are poorly printed and are dotted with typographical errors, but the information 18 there. For information on Councll activities during the perlods for which the Becerds have not been published, particularly 
from February 5 to March 31, 1948, additional sources were employed.

Government of India, Documents Regarding Kashmix, Ministry of External Affairs and Commonwealth Relations, Government of India Information Services, Washington, D.C., n.d.

Government of India. The Kashmir Issue, Ministry of Information and Broadcasting, Publications Division, Delh1, n.d.

Government of India, Some Questions and Answers on Kashmi, India Delegation to the United Nations, New York, n.d.

Government of Ind1a, White Paper on Indian States, Ministry of States, Government of India Press, New Delih1, 1950.

Government of Pakistan, Pakistan. The Strugale of a Nation, Director of Foreign Publicity, Washington, D.C., 1949.

Government of Pakistan, The Story of Kashmir. Pakistan Delegation to the Security council. New York. 1951.

Official publications of the Indian and Pak1stanl governments supplemented information derived from the Council Becords, In particular furnishing a broader base for analysis of Indian and Pakistanl positions. The Pakistanl documents, blatantly propagandistic, state Pakistan's case and attack Ind1a on a number of 1ssues rather than upon Kashmir alone. The Indlan publications are more restrained, consistently stressing the legal approach to the question. The White Paper on Indian States was of great ald as a source of information on the changing policy of the Indian government toward states which have acceded to the Indian Union.

\title{
II
}

\author{
SECONDARY SOURCES
}

\section{A. BOOKS}

Ambedkar, Dr. B. R., Rakistan or the Partition of India, Bombay: Thacker and Co.. 1946, pp. 414.

Arne, Sigrid, United Nations Brimer, rev. ed., New York: RhInehart, 1948, pp. 266.

Brallsford, Henry Noel, Subfect India, New York: John Day. 1943, pp. 274. 
Brierly, J. L.. The Law of Nations, An Introduction to the Internat Ional Law of Peace, 4th ed., Oxford: Clarendon Press, 1949, pp. 228.

de Montmorency, Sir Geoffrey F., The Indian States and Indian Eederat10n, Cambridge: University Press, 1942, pp. 165.

Everymanis Unlted Nations, United Nations Secretarlat, Department of Public Information, New York, 1952, pp. 363.

Hoyl and, John Somervell, Indian Crlsis, the Backareund, New York: Macmillan, 1943, pp. 193.

Jessup, Philip C., A Medern Law of Nations, An Introduction, New York: Macmllian, 1948, pp. 236.

Lovett, Sir Verney, AHistory of the Indian National1st Movement. New York: Frederick A. Stokes, 1920, pp. 285.

Nehru, Jawaharlal, Independence and After, New York: John Day, 1950 , pp. 403.

Oppenhelm, L., International Law, A Ireat1se, Vol. I, Reace, 7 th ed., edited by $H$. Lauterpacht, London: Longmans, Green and Co., 1943, pp. 881.

Ross, Alf, Constitution of the United Nations, Analysis of Structure and Eunctions, New York, Rhinehart, 1950, pp. 232.

United Nations, Yearbook of the United Nations, 1948-50, 3 vols.. New York: Columbia University Fress, 1950, 1951, 1952.

Several of these volumes contributed directly to the body of the thes1s; others were primarily useful as background on Indian history, politics, and religlous problems and on the United Nations. Ambedkar's work is a violently anti-Moslem attack upon the concept of partition, although not following the officlal Congress ine for he favors the two-nation plan as a means of ridding the Indian state of dissident elements. Subject India by Brailsford is a brief, anti-Congress study of Indian politics immediately prior to independence. De Montmorency offers a concise and competent study of the development and pre-independence pattern of the state system and of the meaning of paramountcy. Most of the material for the discussion of the position of the states in Chapter I was drawn from this volume. Indian crists traces the historical development of the nationalist movement. Hoyland 
Is highly critical of Congress, less so of the League. Lovett's study of Indian nationalism, while turgidly written, is undeniably comprehensive for he traces in great detall origins of and influences upon the movement from inception of British rule to the conclusion of the First World war. Independence and After, a collection of speeches and papers by Jawaharlal Nehru, provides insight into the character and thought of the individual who motivates Indian folicy. The legalistic, idealistic Indianaapproach to practical situations is clearly apparent in Nehru's public pronouncements.

As a reference on the international law involved in the Kashmir question, the OppenhelmLauterpacht omnibus is invaluable. Examining law among nations from both the theoretic and the case study approaches, Oppenhelm touches almost every point raised during the dispute. Brlerly's The Law of Vations, while a more readable work, is essentialiy an essay on international legal theory rather than a documented investigation of is practical operation. Jessup follows a simflar pattern with tendencles toward extreme ldealism. Sigrid Arne's study of the United Nations is largely an essay on its genesis and development but also deals with its procedures and capabilities. The Ross study of the United Nations' constitutional basis wes of more pract1cal value to the thesls for Koss thoroughly dissects the significant provisions of the Charter to demonstrate what they mean in practice as well as in wording. Everyman's United Lations, handbook pubilshed by the secretariat, is a useful source for Security Council facts, figures, procedures, and activities. The Yearbook serves a similar purpose. It was particularly useful in charting progress of the Kashmir question in the Security Council.

\section{B. PERIODICALS}

Barton, S1r Will1am, "Pak1stan's Claim to Kashmir," Eoreion Affairs, XXVII (January, 1950), 299-308. 1950), 295.

"Politics in Pakistan," Eertniohtly, ClXXIII (May, "Northwest Frontier," Eortalobtly. CLXXII (August, 1949), 105-11.

"Britain's Proposals on India, June, 1947," Eorelon Policy Beports, XXIII (June 15, 1947), 95-96." 
"British Plan for India," current Histery, XIII (July, 1947), 36-38.

Chandasekhar, S. "Freedom for Incia?" Ear Eastern Survey, XV (July 3, 1946́), 198-200.

Dav1s, Kingsley, "Incila-Pakistan: Demography of Partition," Pacific Affairs, XXII (September, 1949), 254-64.

"Deathbed of Indian Empire," Round Iable, XXXVII (June, 1947), $231-36$.

Finley, Mark, "The Changing Role of the Princes," Centemperary Beview, CLXXVI (October, 1949), 230-35.

FitzGerald-Lee, G., "Kashmir," Centemperary Review, CLXXIX (February, 195i), 93-97.

Griffiths, Sir Percival, "India and Pakistan Today," 12th Century, CXIIII (February, 1948), 61-67. 1947), 205-11. 1948), $11-19$.

Hallfax, Earl of, "India: Two Hundred Years," Eerejon Affairs, XXVI (October, 1947), 104-15.

Harnam Singh, "The Indian States: A Study of Their Constitutional Position, Political Sclence cuarterly, LXIV (March, 1949), 95-106.

"Impact of 1947 Partition Darkens Incials Outlook, "Eereian Policy Bulletin, XXX (November 17, 1950), 2-3.

"Indian Deadlock Unbroken," Round Iable, XXXVII (Niarch, 1947), 167-74.

"India's Fatal Hour," Round Iable, XXXVI (March, 1946), 15358.

"India's Task: Challenge of the Muslim League," Round Table, XXXVI (September, 1946), 340-4E.

"Kashmir and Jarmu," Round Iable, XI (June, 1950), 215-19.

Martin, Kingeley, "As Pakistan Sees It," New Statesman and Nation, XXXV (ifarch 6, 1948), 188-39.

"Pakistan and the Iribes," Bound Table, XXXIX (September, 1949), 329-3ó. 
Parodi, Alexandre, "Peaceful Settlement of D1 sputes," International conciliation, CDXLV (November, 1948), 616-32.

Potter, Pitman B., "Principal Legal and Political Problems In the Kashmir Case," American Journal of International Law, XLIV (Apr11, 1950), 361-63.

Rawlinson, H. G., "Backgrounds: II India," Spectater, CLVIII (Apri1, 25, 1947), 458-59.

"Revolution of the Indian States," Bound Table, XXXIX (December, 1948), 38-43.

Sirdar Ikbal All Shah. "The Future of the Indian States," Eortnightly, CLVIII (August, 1947), 100-05.

Sherwani, Latif Ahmad, "The Basis of Economlc Development in Pak1stan," Raclfic Affairs, XXII (December, 1949), 381-87.

Spate, Dr. O. H. K., "Part1tion of Indla and Prospects of Pakistan," Geographic Beview, XXXVIII (January, 1948), 5-29.

Symonds, Richard, "State-Making in Pakistan," Eax Eastern Suryex, XIX (March 8, 1950), 45-50.

Talbot, PhIllips, "Independence of India," Eoreian Rolicy Beperts, XXIII (June 15, 1947), 74-95.

"India and Pak1stan: Progress Report," Eorelon Bolicy Beports, XXV (June 15, 1949), 73-87.

Thorner, Alice, "Indla-Pakistan Tensions Focus on Kashmir," Eore1gn Rolicy Bulletin, XXIX (March 17, 1950), 2-3.

(August 11, 1948), 173-78.

"Kashmir Conflict," Middle Eastern Journal, III (January, 1949), 17-30; (April, 1949), 164-80.

Thorner, Daniel, "Hindu-Moslem Conflict in India," Ear Eastern Suryey, XVII (Apr11 7, 1948), 77-80.

"Valediction to India," Beund Table, XXXVII (September, 1947), 330-38.

Wade, WIll1am W., "Indla and the Comnonwealth," Eoreion Rolley Beperts, XXV (June 15, 1949), 88.

Wallmaker, I. Walter, "Indla and Paklstan: Can Two NationalIsms Survive?", eurrent H1story, XIX (August, 1950), 83-67. 
A great deal of information on Kashmir immediately prior to invasion and during the course of hostilities as well as on contemporary Indian and Pakistani economic problems, politics, and forelgn policy has been derived from perlodicals. Of particular value were pieces by Alice and Danlel Thorner. "Issues in Kashmir" is the most succinct account of developments in Kashmir between August, 1947 and January, 1948 encountered during research for this study. "India-Pakistan: Demography of Partition" by Kingsley Davis and "Partition of India and Prospects of Pakistan" by Dr. Spate contributed more to an understanding of issues ralsed in Council debates than they did to the body of the thesis. Phillips Talbot, in "Independence of India," provides a thorough analysis of the history and precepts of the Congress party and the Moslem League. "Pakistan and the Tribes" is an informative, and highly sympathetic, survey of present Pak1stani relations with the Fathans. It was of considerable value in supplementing references to this subject in the Council debates. Blas was obvious in several of the selections, notably those authored by Sir William Barton and SIr Percival Griffiths, both violently pro-PakIstan. In general, articles appearing in British publications were inclined to favor Pakistanl. arguments in the Kashmir question.

\section{NEWSPAPERS}

The New York Iimes, August, 1947-July, 1952.

The Ilmes proved invaluable for supplementary background material and for information not avaliable in the Counc1l Records. Coverage of the perlods February 5 to March 31,1948 and May 1 to June 30,1952 was particularly important to the thesis for the official security Council proceedings for these dates are not avallable. Articles covering the early days of Ithe invasion of Kashmir were also of great value. 